Energy Systems Environmental Restoration Program

Clinch River Environmental Restoration Program

\title{
Data Summary for the Near-Shore Sediment Characterization Task of the Clinch River Environmental Restoration Program
}

\author{
D. A. Levine \\ W. W. Hargrove \\ K. R. Campbell \\ M. A. Wood \\ C. D. Rash
}

Date Issued-October 1994

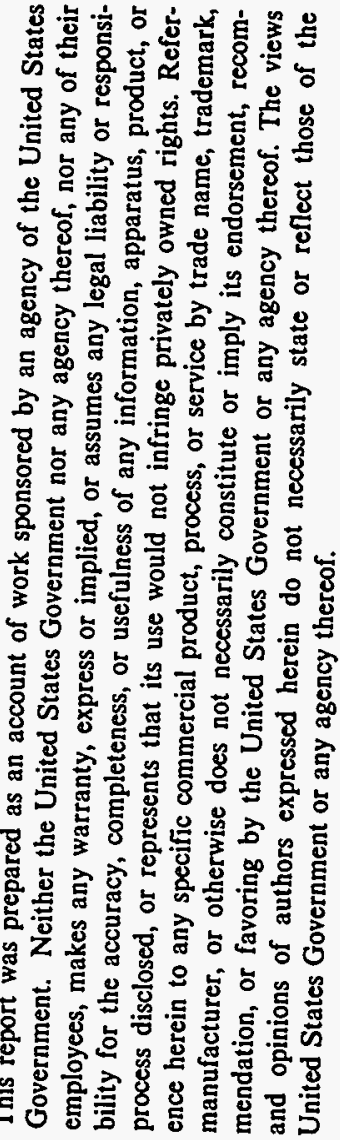

\section{Environmental Sciences Division \\ Oak Ridge National Laboratory \\ ESD Publication 4318}

Prepared by

Prepared for

U.S. Department of Energy

Office of Environmental Management

under budget and reporting code EW 20

OAK RIDGE NATIONAL LABORATORY

Oak Ridge, Tennessee 37831-6285

managed by

MARTIN MARIETTA ENERGY SYSTEMS, INC.

for the

U.S. DEPARTMENT OF ENERGY

under contract DE-AC05-84OR21400

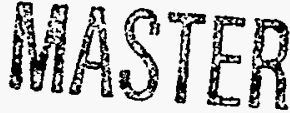

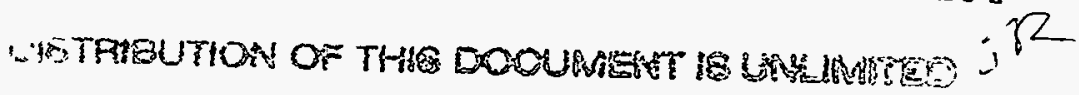




\section{Author Affiliations}

Daniel A. Levine is an employee of the Automated Sciences Group, Inc., Oak Ridge, Tennessee. William W. Hargrove and Kym R. Campbell are with University of Tennessee Energy, Environment, and Resources Center, Knoxville, Tennessee. Clint D. Rash and Mary Alice Wood are members of the Environmental Sciences Division of Oak Ridge National Laboratory, Martin Marietta Energy Systems, Inc., Oak Ridge, Tennessee. 


\section{DISCLAIMER}

Portions of this document may be illegible in electronic image products. Images are produced from the best available original document. 


\section{CONTENTS}

FIGURES $\ldots \ldots \ldots \ldots \ldots \ldots \ldots \ldots \ldots \ldots \ldots \ldots \ldots \ldots \ldots \ldots \ldots \ldots$

TABLES $\ldots \ldots \ldots \ldots \ldots \ldots \ldots \ldots \ldots \ldots \ldots \ldots \ldots \ldots \ldots \ldots \ldots \ldots \ldots$

ABBREVIATIONS $\ldots \ldots \ldots \ldots \ldots \ldots \ldots \ldots \ldots \ldots \ldots \ldots \ldots \ldots \ldots \ldots$

EXECUTIVE SUMMMARY $\ldots \ldots \ldots \ldots \ldots \ldots \ldots \ldots \ldots \ldots \ldots \ldots \ldots \ldots$

1. INTRODUCTION $\ldots \ldots \ldots \ldots \ldots \ldots \ldots \ldots \ldots \ldots \ldots \ldots \ldots \ldots \ldots \ldots \ldots$ 1-1

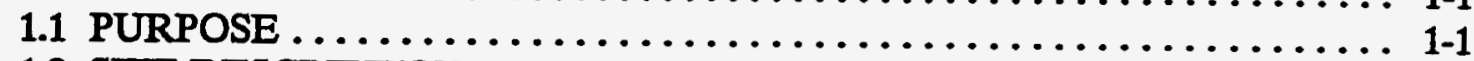

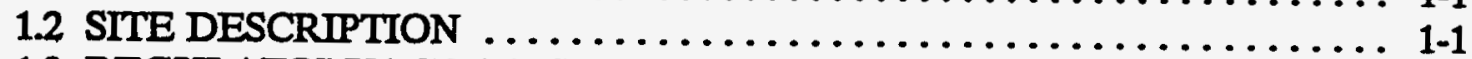

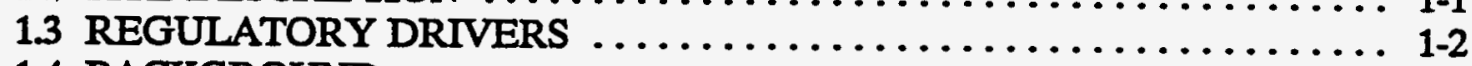

1.4 BACKGROUND . . . . . . . . . . . . . . . . . . . . . . $1-2$

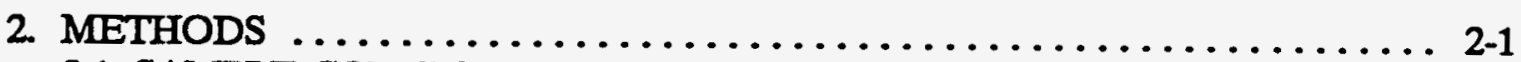

2.1 SAMPLE COLLECTION DESIGN $\ldots \ldots \ldots \ldots \ldots \ldots \ldots \ldots \ldots \ldots \ldots \ldots . \ldots \ldots$

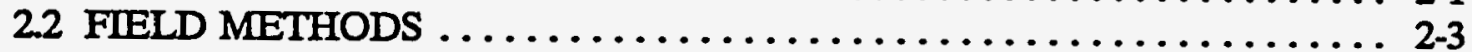

2.3 LABORATORY METHODS $\ldots \ldots \ldots \ldots \ldots \ldots \ldots \ldots \ldots \ldots \ldots . \ldots \ldots$

24 QUALITY CONTROL METHODS $\ldots \ldots \ldots \ldots \ldots \ldots \ldots \ldots \ldots \ldots \ldots$

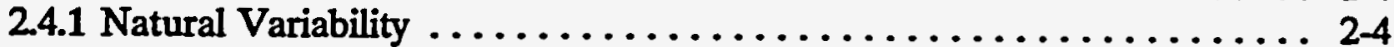

2.4.2 Sampling Methods ............................. 2-4

2.4 .3 Laboratory Accuracy $\ldots \ldots \ldots \ldots \ldots \ldots \ldots \ldots \ldots \ldots \ldots \ldots . \ldots \ldots$

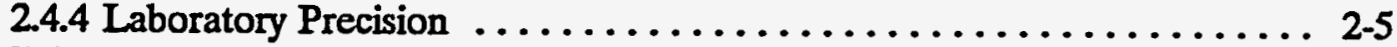

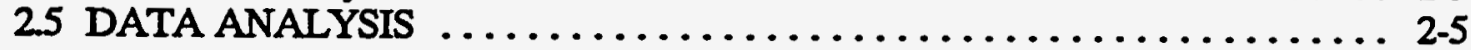

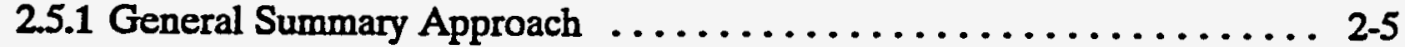

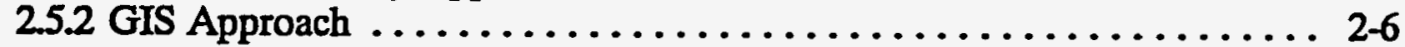

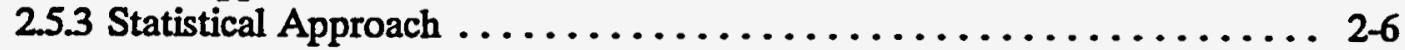

2.5 .4 Risk Approach $\ldots \ldots \ldots \ldots \ldots \ldots \ldots \ldots \ldots \ldots \ldots \ldots \ldots . \ldots \ldots$

3. RESULTS AND DISCUSSION ....................... 3-1

3.1 SUMMARY OF ${ }^{137}$ CS CONCENTRATIONS IN SURFACE SEDIMENTS . 3-1

3.1.1 Concentrations By Study Reach ................... 3-1

3.1 .2 Concentrations By River Mile ................... 3-2

3.1 .3 ANOVAs .............................. $3-4$

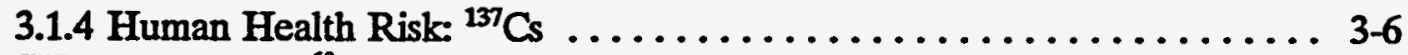

3.2 SUMMARY OF ${ }^{60} \mathrm{CO}$ CONCENTRATION IN SURFACE SEDIMENTS . . 3-7

3.21 Concentrations By Study Reach . . . . . . . . . . . . . . 3-7

3.2 .2 Concentrations By River Mile $\ldots \ldots \ldots \ldots \ldots \ldots \ldots \ldots \ldots \ldots . \ldots \ldots$

3.23 ANOVAs . . . . . . . . . . . . . . . . . . . . . .

3.2 .4 Human Health Risk . . . . . . . . . . . . . . . . . . 3-11

3.3 SEDIMENT CLASSIFICATION ANALYSIS $\ldots \ldots \ldots \ldots \ldots \ldots \ldots \ldots .12$ 
3.4 QUALITY CONTROL ANALYSIS $\ldots \ldots \ldots \ldots \ldots \ldots \ldots \ldots \ldots \ldots \ldots \ldots$

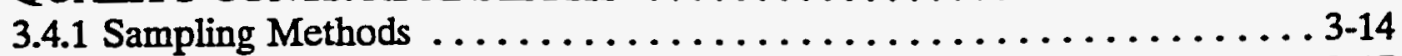

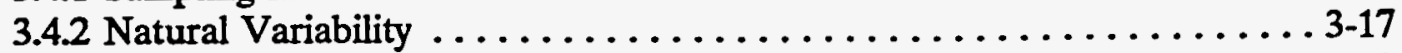

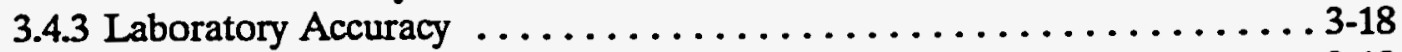

3.4.4 Laboratory Precision $\ldots \ldots \ldots \ldots \ldots \ldots \ldots \ldots \ldots \ldots . . \ldots \ldots$ 3-19

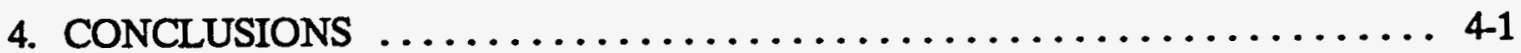

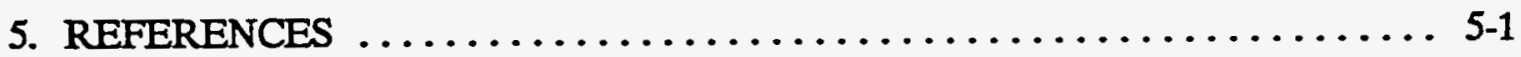

Appendix A HUMAN HEALTH RISK CALCULATIONS FOR ${ }^{137} \mathrm{Cs}$ AND ${ }^{60} \mathrm{Co}$ IN SURFACE SEDIMENTS USING THE DIRECT EXPOSURE PATHWAY $\ldots \ldots \ldots \ldots \ldots \ldots \ldots \ldots$ A-1

Appendix B. CESIUM-137 AND COBALT-60 CONCENTRATION DATA AND HUMAN HEALTH RISK VALUES, SUMMARIZED BY RIVER MILES ................. B-1

Appendix C. SUMMARY OF BRADEN BRANCH DATA $\ldots \ldots \ldots \ldots \ldots \ldots,-1$ 


\section{FIGURES}

1.1 Clinch River/WBR study area $\ldots \ldots \ldots \ldots \ldots \ldots \ldots \ldots \ldots \ldots \ldots$

2.1 Distribution of ${ }^{137} \mathrm{Cs}$ in surface sediments of WBR $\ldots \ldots \ldots \ldots \ldots \ldots$

2.2 Distribution of log-transformed ${ }^{137} \mathrm{Cs}$ in surface sediments of WBR $\ldots \ldots \ldots$ 2-8

3.1 Mean cesium-137 concentrations relative to distance downstream from WOCE

3.2 Mean cobalt- 60 concentrations relative to distance downstream from WOCE 


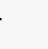




\section{TABLES}

2.1 Stream and river reaches used in the CR-ERP RIFS ............ 2-1

3.1 Number of samples collected in each study reach $\ldots \ldots \ldots \ldots \ldots \ldots \ldots \ldots$

3.2 Summaries for ${ }^{137} \mathrm{Cs}$ concentrations in surface sediment for each

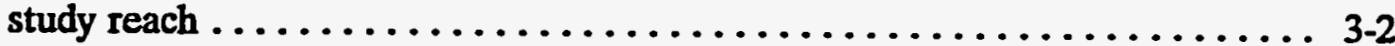

3.3 Results of ANOVA for explaining variability of ${ }^{137} \mathrm{Cs}$ concentrations in surface sediment samples collected downstream of CRM $1 \ldots \ldots \ldots \ldots . . .4-4$

3.4 Summary of ${ }^{137} \mathrm{Cs}$ concentrations in surface sediments above and below $735 \mathrm{ft}$ msl, by reach $\ldots \ldots \ldots \ldots \ldots \ldots \ldots \ldots \ldots \ldots \ldots . \ldots \ldots$

3.5 Results of ANOVA for explaining variability of ${ }^{137} \mathrm{Cs}$ concentrations in the samples from the Clinch River and lower WBR

3.6 Sediment ${ }^{137} \mathrm{Cs}$ concentration that would produce a $1 \times 10^{-4}$ cancer risk based on parameter values and equations used in RI/FS for lower WBR

3.7 Summary of ${ }^{60} \mathrm{Co}$ concentrations for each study reach $\ldots \ldots \ldots \ldots \ldots \ldots \ldots$

3.8 Results of ANOVA for explaining variability of ${ }^{60} \mathrm{Co}$ concentrations

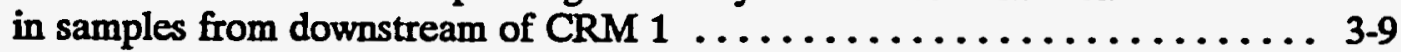

3.9 Summary of ${ }^{60} \mathrm{Co}$ concentrations above and below $735 \mathrm{ft}$ msl, by reach . . . . 3-10

3.10 Results of ANOVA for explaining variability of ${ }^{60} \mathrm{Co}$ concentrations in the samples from the Clinch River and lower WBR

3.11 Sediment ${ }^{60} \mathrm{Co}$ concentration that would produce a $1 \times 10^{4}$ cancer risk based on parameter values and equations used in the RI/FS for lower WBR

3.12 Particle size ranges for each class in the three-category

cluster analysis

3.13 Particle size ranges for each class in the four-category

cluster analysis

3.14 Comparison of visual/physical and statistical sediment type classification schemes

3.15 DERs for radionuclide concentrations of field splits of sediment grabs .... 3-16 
3.16 Summary of ${ }^{137} \mathrm{Cs}$ concentrations ( $\mathrm{pCi} / \mathrm{g}$ dry weight) for field replicates

3.17 Summary of ${ }^{60} \mathrm{Co}$ concentrations (pCi/g dry weight) for field replicates 3-18

3.18 Comparison of analysis of split samples analyzed by ESD RAL and TDEC laboratory

3.19 Comparison of sample weights for split samples analyzed by ESD RAL and TDEC laboratory

3.20 DERs for laboratory replicate sample analyses 3-20 


\section{ABBREVIATIONS}

$\begin{array}{ll}\text { ANC } & \text { American Nuclear Corporation } \\ \text { ANOVA } & \text { Analysis of variance } \\ \text { CERCLA } & \text { Comprehensive Environmental Response, Compensation, and Liability Act } \\ \text { CR-ERP } & \text { Clinch River Environmental Restoration Program } \\ \text { CRM } & \text { Clinch River Mile } \\ \text { DER } & \text { Duplicate error ratio } \\ \text { DOE } & \text { Department of Energy } \\ \text { ESD } & \text { Environmental Sciences Division } \\ \text { EPA } & \text { Environmental Protection Agency } \\ \text { HSWA } & \text { Hazardous and Solid Waste Amendments } \\ \text { ORNL } & \text { Oak Ridge National Laboratory } \\ \text { ORR } & \text { Oak Ridge Reservation } \\ \text { RAL } & \text { Radiochemical Analysis Laboratory } \\ \text { RCRA } & \text { Resource Conservation and Recovery Act } \\ \text { RIFS } & \text { Remedial Investigation/Feasibility Study } \\ \text { SAS } & \text { Statistical Analysis System } \\ \text { TDEC } & \text { Tennessee Department of Environment and Conservation } \\ \text { TRM } & \text { Tennessee River Mile } \\ \text { TVA } & \text { Tennessee Valley Authority } \\ \text { WBR } & \text { Watts Bar Reservoir } \\ \text { WBRIPG } & \text { Watts Bar Reservoir Interagency Permitting Group } \\ \text { WOC } & \text { White Oak Creek } \\ \text { WOCE } & \text { White Oak Creek Embayment } \\ & \end{array}$




\section{EXECUTIVE SUMMARY}

The purpose of the Near-Shore Sediment Characterization Task of the Clinch River Environmental Restoration Program (CR-ERP) was to quantify potential human health risks associated with Department of Energy (DOE)-related contamination of surface sediments in Watts Bar Reservoir (WBR). An estimated $700 \mathrm{Ci}$ of ${ }^{137} \mathrm{Cs}$ and $325 \mathrm{Ci}$ of ${ }^{60} \mathrm{Co}$ were released from White Oak Lake into the Clinch River between 1949 and 1992 (DOE 1988). A number of previous studies have documented sediment contamination in the deep-water sediments but no study specifically targeted the near-shore environment, which has the most potential for exposure to humans.

Between 1991 and 1994, a total of 926 surface sediment grab samples were collected and analyzed for gamma-emitting radionuclide $\left({ }^{137} \mathrm{Cs}\right.$ and $\left.{ }^{60} \mathrm{Co}\right)$ concentrations. Nearly 500 samples were collected along the shoreline of lower WBR; over 300 samples were collected along the shoreline and in deposition zones in the Clinch River arm of WBR; and the remaining samples were collected in the Tennessee and Emory River arms of WBR, Poplar Creek, Melton Hill Reservoir, and Norris Reservoir. Human health risks associated with ${ }^{137} \mathrm{Cs}$ and ${ }^{60} \mathrm{Co}$ in surface sediment were estimated. A rigorous field and laboratory quality control program was implemented to ensure data quality and to enable quantification of uncertainties associated with the data.

Two methods of human health risk calculations were used. First, a screening method was developed that determined the concentrations of both ${ }^{137} \mathrm{Cs}$ and ${ }^{60} \mathrm{Co}$ that would result in a greater than $1 \times 10^{-4}$ risk of cancer through the external exposure pathway. With this method, a concentration of $15 \mathrm{pCi} / \mathrm{g}$ of either ${ }^{137} \mathrm{Cs}$ or ${ }^{60} \mathrm{Co}$ would result in an unacceptable risk. The human health baseline risk method used by the CR-ERP was also employed by back calculating concentrations of ${ }^{137} \mathrm{Cs}$ and ${ }^{60} \mathrm{Co}$ that would result in a risk greater than $1 \times 10^{-4}$ for six different pathways: direct exposure, ingestion, inhalation, eating vegetables grown on dredged sediments, and consuming the meat or milk from animals that have grazed in dredged sediment areas. The direct exposure pathway posed the most risk to human health. Concentrations of ${ }^{137} \mathrm{Cs}$ and ${ }^{60} \mathrm{Co}$ that would yield a risk of greater than $1 \times 10^{-4}$ were 11.5 and $7.3 \mathrm{pCi} / \mathrm{g}$ respectively.

Concentrations of ${ }^{137} \mathrm{Cs}$ and ${ }^{60} \mathrm{Co}$ are highest near the source, White Oak Creek, with a fairly constant average concentration within the Clinch River arm of WBR. Concentrations are dramatically lower downstream of the confluence of the Tennessee and Clinch River arms. Concentrations of ${ }^{137} \mathrm{Cs}$ and ${ }^{60} \mathrm{Co}$ in the Emory and Tennessee rivers near their confluences with the Clinch River suggest some contamination due to reverse flows in the system.

While ${ }^{137} \mathrm{Cs}$ and ${ }^{60} \mathrm{Co}$ contamination in WBR is present, the concentrations are low and are less than concentrations that result in greater than $1 \times 10^{-4}$ human health risk. Concentrations of ${ }^{137} \mathrm{Cs}$ and ${ }^{60} \mathrm{Co}$ rarely exceeded critical values. Samples from lower WBR, between winter and summer lake pool, never exceeded critical values. Samples in these areas never exceeded 2.pCi/g ${ }^{137} \mathrm{Cs}$. A few locations in lower WBR, in deep water greater than $20 \mathrm{ft}$, did approach $10 \mathrm{pCi} / \mathrm{g}{ }^{137} \mathrm{Cs}$. Samples from shallow areas throughout the WBR never exceeded the concentrations that would yield a risk greater than $1 \times 10^{-4}$. Several 1-mile reaches in the Clinch River arm of WBR had individual samples that exceeded the $11.5-\mathrm{pCi} / \mathrm{g}$ value for ${ }^{137} \mathrm{Cs}$. The average ${ }^{137} \mathrm{Cs}$ concentrations in the 1-mile reach around these samples 
did not exceed the risk-based criteria. Cobalt- 60 concentrations in WBR are well below values that would exceed a $1 \times 10^{-4}$ human health risk. However, the Braden Branch area of Melton Hill Reservoir did have ${ }^{60} \mathrm{Co}$ concentrations that were higher than the rest of the study area but still below the risk-based criteria. This area, contaminated by an old medical supply company that is a State of Tennessee Superfund Site, is not related to DOE activities.

The results of the field and laboratory quality control program suggest that the data collected during this task are of high quality. The number of samples distributed throughout the system is high, the field and laboratory methods proved precise and accurate, and the risk methodology is generally conservative. The uncertainty of the calculated risk is low, and thus, the conclusion-that the risk to human health associated with direct exposure to ${ }^{137} \mathrm{Cs}$ and ${ }^{60} \mathrm{Co}$ concentrations in the surface sediments of WBR is low-is well founded. 


\section{INTRODUCTION}

\section{PURPOSE}

This report presents the results of the Near-Shore Sediment Characterization Task of the Clinch River Environmental Restoration Program (CR-ERP). The goals of the task were to (1) determine the extent to which near-shore surface sediments are contaminated by releases from the Oak Ridge Reservation (ORR) and (2) provide data for the Watts Bar Reservoir Interagency Permitting Group (WBRIPG) to evaluate the human health risks from exposure to sediments during and following dredging operations. The data collected for this task are also to be used in the Remedial Investigation/Feasibility Study (RI/FS) for the CR-ERP operable units (Lower Watts Bar and Clinch River) to characterize the human health risk associated with exposure to near-shore sediments throughout the Watts Bar Reservoir.

\section{SITE DESCRIPTION}

The CR-ERP focuses on those portions of the Clinch and Tennessee rivers that may have been adversely affected by contaminants released from the mid-1940s to present from the Department of Energy (DOE) ORR. The contaminants released from the ORR to the Clinch and Tennessee rivers originated from research, industrial, and waste disposal activities conducted at Oak Ridge National Laboratory (ORNL), the Oak Ridge Gaseous Diffusion Plant (now known as the K-25 Site), and the Oak Ridge Y-12 Plant. These contaminants include a variety of radionuclides, metals, and organic compounds. Between 1949 and 1992 , an estimated $700 \mathrm{Ci}$ of ${ }^{137} \mathrm{Cs}$ (30-yr half-life) and $325 \mathrm{Ci}$ of ${ }^{60} \mathrm{Co}$ (5-yr half-life) were released from White Oak Lake into the Clinch River. Peak releases of ${ }^{137} \mathrm{Cs}$ and ${ }^{60} \mathrm{Co}$ occurred in 1956, coinciding with the draining of White Oak Lake. Both ${ }^{137} \mathrm{Cs}$ and ${ }^{60} \mathrm{Co}$ are particle reactive, which means they are readily adsorbed to the surfaces of fine-grained sediment particles. Because the release history of ${ }^{137} \mathrm{Cs}$ is known and measuring ${ }^{137} \mathrm{Cs}$ is comparatively inexpensive, it is useful as a screen for where other DOE-originating contaminants could be found. In addition, the Clinch River/Watts Bar Reservoir system receives effluents from municipal and industrial water treatment facilities and runoff from agricultural and urban areas.

Melton Hill Reservoir and Clinch River (downstream from Melton Hill Dam) form the southern and eastern boundaries of the ORR (Fig. 1.1). All surface water draining the ORR eventually enters the Clinch River system. The Clinch River flows into the Tennessee River system of multiple-purpose impoundments near Kingston, Tennessee, $34 \mathrm{~km}$ downstream from the ORR (Fig. 1.1). Watts Bar Reservoir extends from Watts Bar Dam, at Tennessee River Mile (TRM) 530, to Fort Loudon Dam, at TRM 602, and up the Clinch River to Melton Hill Dam, at Clinch River Mile (CRM) 23.9. Chickamauga Reservoir is the next mainstem impoundment downstream of Watts Bar Dam. The river-reservoir system is 140 river miles in length and 44,000 acres in surface area and is used for municipal water supply, sport fishing, boating, and swimming; and as a focal point for tourism and residential development.

Tennessee Valley Authority (TVA) manages the water levels in the reservoir system to meet their multipurpose objectives. Therefore, water levels vary seasonally, weekly, daily, and hourly to meet the needs of flood storage, power generation, cold water supply for 
downstream cooling towers, mosquito control, and fisheries. The changing lake elevations strongly influence the location and quantity of sediment deposits in the system.

\subsection{REGULATORY DRIVERS}

The ORR was added to the National Priorities List in December 1989. A Federal Facility Agreement (FFA) [under Section 120 of the Comprehensive Environmental Response, Compensation, and Liability Act (CERCLA) as amended by the Superfund Amendment and Reauthorization Act and Section 6001 of the Resource Conservation and Recovery Act (RCRA) of 1976] between DOE, the U.S. Environmental Protection Agency (EPA) Region IV, and the Tennessee Department of Environment and Conservation (TDEC) became effective on January 1, 1992. These parties intend to coordinate DOE's CERCLA/RCRA response obligation with the corrective measures required and conducted by DOE under its current permit under the Hazardous and Solid Waste Amendments (HSWA) of 1984 to RCRA Section 3004(v) of the HSWA of RCRA specifically addresses requirements for corrective actions related to releases of hazardous wastes or constituents beyond the boundaries of RCRA-permitted sites. In addition, TDEC, DOE, and EPA expect that the response actions under the FFA, together with corrective measures, will achieve comprehensive remediation of releases and potential releases of contaminants from the ORR. The CR-ERP is being conducted in compliance with the FFA and with Section 3004(v) of RCRA.

\subsection{BACKGROUND}

A number of studies have documented contamination in sediments in the Watts Bar Reservoir system resulting from releases by the DOE facilities in Oak Ridge (Struxness et al. 1967, Oakes et al. 1982, Olsen et al. 1992, Turner et al. 1984, TVA 1986). The predominant contaminant is ${ }^{137} \mathrm{Cs}$, which was released from ORNL through White Oak Lake. Mercury, which was predominantly released from the Y-12 Plant through East Fork Poplar Creek, is also a concern. As these studies progressed, it became evident that the majority of ${ }^{137} \mathrm{Cs}$ had accumulated in deep-water sediments (Olsen et al. 1992, Oakes et al. 1982). Mercury concentrations were shown to be highly correlated with ${ }^{137} \mathrm{Cs}$ concentrations in the reservoir (Olsen et al. 1992). Therefore, much of the research has concentrated in the deep-water sediments with little attention to the near-shore environment.

While early data in the Clinch River arm of the Watts Bar Reservoir (WBR) showed little ${ }^{137} \mathrm{Cs}$ contamination in shallow near-shore environments (mostly embayments off the main river channel), no conclusive study was performed to determine near-shore contaminant levels in lower Watts Bar Reservoir (downstream of the confluence of the Tennessee and Clinch rivers). It was important to characterize these near-shore areas because this is where most direct human exposure to sediments occurs. Human exposure to near-shore sediment occurs through several activities: wading, walking along exposed sediment during winter months, and direct exposure to dredge sediments. The reservoir water level is drawn down from $741 \mathrm{ft}$ msl in summer to $735 \mathrm{ft}$ msl during winter months (September through April, depending on rainfall), uncovering a large area of sediment. Also, shoreline development has resulted in dredging activity for boat docks, channels, etc., and the dredged material is typically disposed of on land. 
In February 1991, the Watts Bar Reservoir Interagency Permit Group (WBRIPG) was formed from representatives of the U.S. Army Corps of Engineers (ACOE), TVA, DOE, EPA, and TDEC. TVA [through Sects. 26a, 4(k), and 31], and EPA and ACOE, (through Sect. 10 of the Rivers and Harbors Act of 1899 and Sect. 404 of the Clean Water Act), were authorized to regulate activities that would disturb sediments in waters of the United States. TVA and ACOE both review permits for such activities in WBR. The WBRIPG was formed to evaluate dredging permits to determine if a proposed activity would disturb contaminated sediments and thereby pose a human health risk. The WBRIPG evaluation process uses ${ }^{137} \mathrm{Cs}$ concentrations as an indicator of contamination. The WBRIPG has set a limit for acceptable contamination of $15 \mathrm{pCi} / \mathrm{g}$, which is based on human health risk estimates. If ${ }^{137} \mathrm{Cs}$ concentrations in the sediment at a proposed site are below $15 \mathrm{pCi} / \mathrm{g}$, the permit is passed to ACOE and TVA for standard permit review. If concentrations are above $15 \mathrm{pCi} / \mathrm{g}$, a more detailed sampling and analysis of the area is required. The initial area of concern for the WBRIPG was the Tennessee River, from TRM 529.9 (Watts Bar Dam) to TRM 569 (Webster Bluff Light), just upstream from the confluence of the Tennessee and Clinch rivers; the Clinch River, from CRM 0 (mouth of the Clinch River at TRM 567.5) to CRM 20.8 (confluence of White Oak Creek and Clinch River); and the Emory River, from Emory River Mile (ERM) 0 (mouth at CRM 4.3) to ERM 5.2 (downstream from the confluence of the Little Emory River). Based on early results from this study, the WBRIPG removed from further consideration the areas above $735 \mathrm{ft}$ msl from Watts Bar Dam upstream to, and including, the Emory River. 


\section{METHODS}

Sampling during this task was concentrated on near-shore areas where human exposure to sediment is most likely. These areas are exposed for several months every winter and are also the most likely to be disturbed. The general approach was to sample the near-shore sediment environments to characterize the near-shore area throughout the system. In addition, samples were collected at those sites where dredge permit applications were submitted to the WBRIPG to assess the impact of the proposed actions. Late in the project, it was decided that it would be useful to obtain samples from deeper areas off the main channel in lower WBR where sediment accumulation was more likely yet disturbance activities were still possible. It was also decided that surface sediment samples would be collected across the channel in a series of transects in the Clinch River arm and immediately downstream of the White Oak Creek Embayment (WOCE). This design was selected to determine contaminant distribution in the surface sediments immediately downstream of the source.

\subsection{SAMPLE COLLECTION DESIGN}

To facilitate data collection and analysis, the WBR/Clinch River system was divided into study reaches based on hydrologic influences (Table 2.1 and Fig. 1.1).

Table 21. Stream and river reaches used in the CR-ERP RI/FS

\begin{tabular}{|c|c|c|}
\hline Reach & Reach name (description) & River mile \\
\hline 1 & Melton Hill Reservoir (from Oak Ridge Marina to Melton Hill Dam) & $\begin{array}{l}\text { CRM } \\
23.1-52.0\end{array}$ \\
\hline 2 & Clinch River (from Melton Hill Dam to Poplar Creek) & $\begin{array}{l}\text { CRM } \\
12.1-23.0\end{array}$ \\
\hline 3 & $\begin{array}{l}\text { Poplar Creek (from confluence with East Fork Poplar Creek to } \\
\text { confluence with Clinch River) }\end{array}$ & PCM 0.0-5.5 \\
\hline 4 & $\begin{array}{l}\text { Clinch River (from confluence with Poplar Creek to confluence with } \\
\text { Tennessee River) }\end{array}$ & CRM 0.0-12.0 \\
\hline 5 & $\begin{array}{l}\text { Watts Bar Reservoir (from confluence of Tennessee and Clinch } \\
\text { Rivers to Watts Bar Dam) }\end{array}$ & $\begin{array}{l}\text { TRM } \\
530.0-567.5\end{array}$ \\
\hline 6 & Emory River & ERM 0.0-14.0 \\
\hline 10 & Norris Reservoir & \\
\hline 13 & Poplar Creek (upstream from confluence of East Fork Poplar Creek) & PCM 5.6-120 \\
\hline 18 & $\begin{array}{l}\text { Tennessee River arm of Watts Bar Reservoir (from Fort Loudon and } \\
\text { Tellico Dams to confluence with Clinch River) }\end{array}$ & $\begin{array}{l}\text { TRM } \\
567.6-602.0\end{array}$ \\
\hline
\end{tabular}

-CRM = Cinch River Mile, PCM = Poplar Creek Mile, TRM = Tennessee River Mile, ERM = Emory River mile.

Reaches 1 through 5 are considered to be downstream of potential effects from DOE releases. Reaches 10 and 13 are upstream of DOE influences and are considered to be reference reaches. Reaches 6 and 18 flow into reaches that are downstream of DOE 


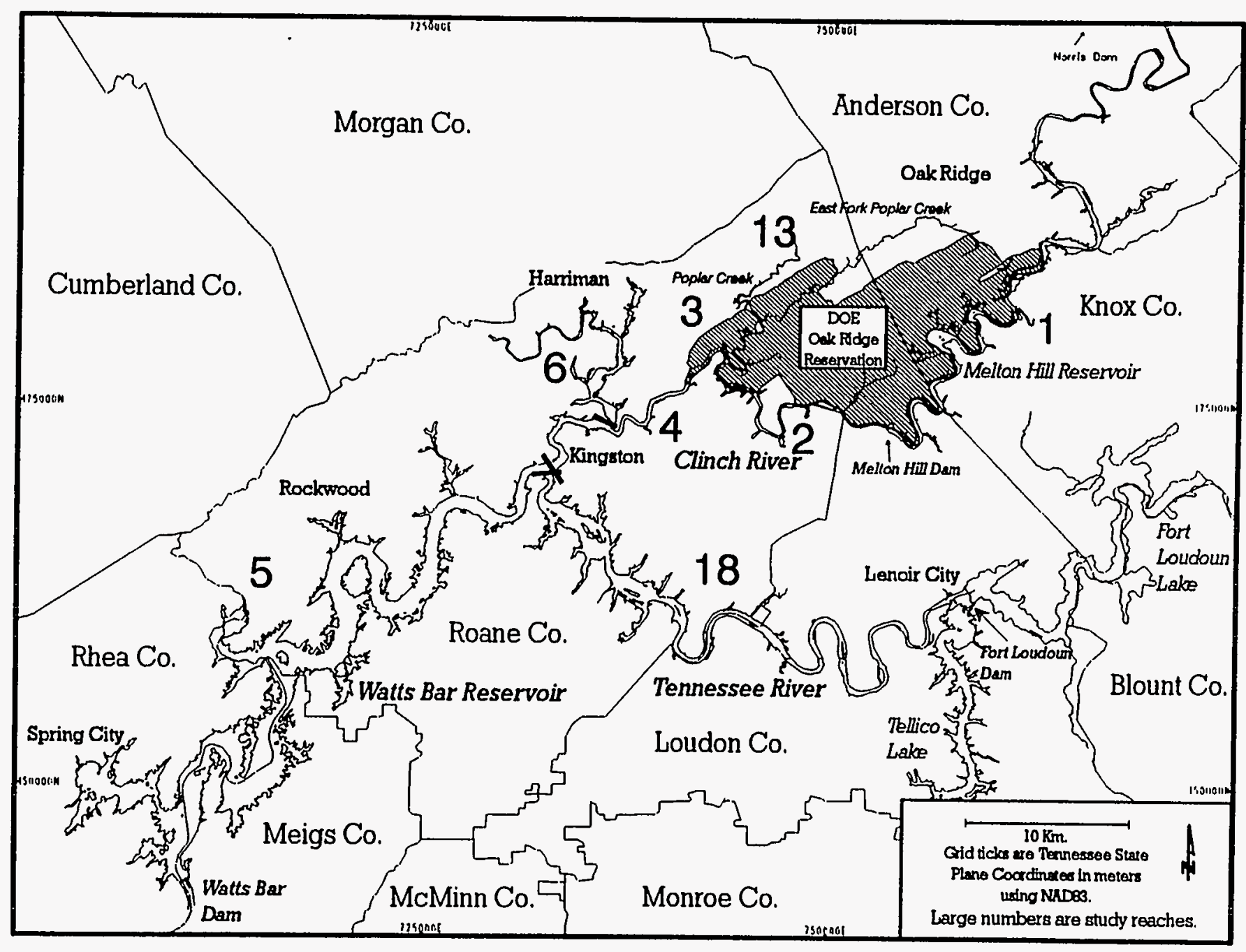

Figure 1.1. Clinch River/Watts Bar Reservoir study area.

Large numbers correspond to study reaches listed in Table 2.1. 
influences and may have some perceptible influences from DOE-related discharges because of backflow under certain reservoir operating conditions. Reaches 2 through 6 and the downstream end of Reach 18 were sampled during this study and are considered potentially contaminated. Reach 10 was sampled to serve as a reference for this study. A few samples were also collected at the mouth of Poplar Creek (Reach 3).

The overall sample collection design was to sample shoreline areas where human contact was most likely. Areas near marinas, active developments, and permit application locations were specifically targeted. For permit application locations, at least three samples were taken. In cases where sediment deeper than $10-15 \mathrm{~cm}$ was to be disturbed, a sediment core was collected. The focus of much of the sampling was in lower WBR (Reach 5) and the Emory River (Reach 6). As the results of this sampling design were analyzed, it became clear that nearly all the near-shore sediments were influenced by local sedimentation processes, with little or no impact from sediment originating from DOE sources. Therefore, the deeper portions of embayments and coves in lower WBR were sampled to determine if these areas were influenced by contaminated sediment originating from the ORR. Also, samples in the Clinch River arm of the reservoir were collected along transects immediately below the confluence with White Oak Creek and in sedimentation zones downstream. These areas included Jones Island, Grubb Island, and a submerged sand island near CRM 15. The purpose of this sampling was to determine if contaminants were present in the surface sediment in deeper water, either from scouring of clean sediment down to layers where ${ }^{137} \mathrm{Cs}$ peaks had been deposited earlier; from remobilization of in-stream sediment; or from recent releases from White Oak Creek, which would be particularly important especially because of the recent coffer-cell dam construction.

\section{FIELD METHODS}

Between 3 and 20 samples were collected each sampling day at planned locations. Sample locations were located on field maps (copies of navigation charts or United States Geological Survey 7.5 minute quadrangle sheets). These locations were later digitized as input into a geographic information system (GIS). Sample locations were also determined in the field using a range finder to obtain distances from three landmarks; this information was recorded in the field logbook. Surface sediment grabs were collected in accordance with procedures outlined in ER/CR-SOP2220, which required that a grab sample be collected with a Ponar grab sampler, emptied into a large tub, and homogenized by mixing thoroughly with a spoon. A portion of the sample was then placed in a $500 \mathrm{~mL}$ or $1 \mathrm{~L}$ Marinelli beaker. Container lids were taped to prevent leakage and a custody seal was placed across the lid, extending onto the main part of the container. The sample was then placed in doubled plastic bags to contain any leakage should a container break or a lid come loose. All equipment (Ponar, homogenizing tub, and mixing spoon) were scrubbed and rinsed with ambient lake water between each sample. Sediment type, water depth, and approximate river mile (in tenths of miles) were recorded in the field logbook at each site.

The sediment type was determined by a subjective visual and physical inspection of the sediment sample. An attempt was made to make these descriptive classes match those used by Olsen et al. (1992): soft mud, cohesive mud, sandy mud, sand and gravel, and submerged soil. A statistical evaluation of how well this subjective description indicates truly different sediment classes was performed and is described below. Locations were also recorded for sites 
where an attempt was made to collect sediment but no sediment was found; in these cases the reservoir bottom was either bedrock or hard-packed clay.

\section{LABORATORY METHODS}

Tare weights of Marinelli beakers were obtained using a Mettler balance and recorded directly on the container. Upon return from the field, sample wet weights (which included the plastic bags and tape) were measured. All container weights and sample weights for each sample number were recorded in a logbook.

Samples were transferred to the Environmental Sciences Division (ESD) Radiochemical Analysis Laboratory (RAL), with the chain of custody being maintained at all times. The samples were radiochemically analyzed using germanium solid state detectors. A Nuclear Data 9900 or a Genie PC acquisition system was used to record ${ }^{137} \mathrm{Cs}$ and ${ }^{60} \mathrm{Co}$ decays. Counting times for each sample ranged from 60 to 1000 minutes or longer, depending on the activity present and the degree of precision desired. Activity data were electronically transmitted to a Statistical Analysis System (SAS) data set.

Following gamma spectrometry, the samples and custody were returned to the CR-ERP laboratory personnel for sample drying. The plastic bags were opened, the tape was removed (but kept with each sample), and the lid was opened. Samples were placed in a Blue M oven at 60 degrees $C$ for at least 3 days. Sample dry weights and combined weights with the tape and bags were obtained and recorded in the same logbook as the wet weights. Weight data were entered into a SAS data set, combined with the activity data, and ${ }^{137} \mathrm{Cs}$ and ${ }^{60} \mathrm{Co}$ concentrations were calculated ( $\mathrm{pCi} / \mathrm{g}$ dry weight).

\section{QUALITY CONTROL METHODS}

There were several types of quality control samples collected throughout the project. Each type was designed to quantify variability contributed by field and laboratory methods or field conditions.

\subsection{Natural Variability}

At least three samples were collected at each permit location (relatively small areas, usually about $30 \mathrm{~m} \times 30 \mathrm{~m}$ ). Data from each permit site sampled were analyzed as field replicates to quantify environmental variability of ${ }^{137} \mathrm{Cs}$ and ${ }^{60} \mathrm{Co}$ concentrations. The coefficient of variation (CV), expressed as a percentage, was calculated to give a quantitative measure of variability with respect to the mean concentration.

\subsection{Sampling Methods}

Often, a single Ponar grab would yield more than enough sediment to fill a Marinelli beaker. When this occurred, the sampling crew would homogenize the sample and fill the Marinelli beaker from the homogenate. Therefore, it is important to be able to quantify the variability between duplicate samples collected from the same homogenate. 
A field split was collected once for every 20 samples by placing several Ponar samples from the same location directly from the Ponar dredge sampler into a high-density polyethylene tub, homogenizing the sediment, and filling two separate Marinelli beakers with the homogenized sediment. The variability this method addresses is that associated with the homogenization process.

The field splits were evaluated using the duplicate error ratio (DER) for ${ }^{137} \mathrm{Cs}$ and ${ }^{60} \mathrm{Co}$. The calculation for DERs is:

$\operatorname{DER}=[\mathrm{ABS}(\mathrm{S}-\mathrm{D})] /\left(2 \sigma_{s}+2 \sigma_{\mathrm{D}}\right)$

where: $\mathrm{ABS}=$ absolute value of resulting number

S = first sample value

D $\quad=$ second sample value

$2 \sigma_{3} \quad=$ first sample uncertainty

$2 \sigma_{\mathrm{D}} \quad=$ second sample uncertainty

If the DER is greater than one, then the samples are considered to be significantly different, and insufficient or inadequate on-board homogenization is indicated.

\section{Laboratory Accuracy}

Field splits were also collected on one occasion, and analyses were performed by different laboratories. On July 28, 1992, three sediment grab samples were collected along a transect across Watts Bar Reservoir at CRM 6.7. These samples were split into two aliquots. The CR-ERP and TDEC each took an aliquot from each sample. The CR-ERP analyzed their samples for gamma-emitting radionuclide concentrations following procedures used throughout the near-shore sediment project. The TDEC analyzed their set of aliquots for a set of radionuclides that included gamma-emitters. Analytes that were measured by both laboratories were ${ }^{137} \mathrm{Cs},{ }^{60} \mathrm{Co}$ and ${ }^{40} \mathrm{~K}$. The results of these analyses were compared sample by sample.

\subsection{Laboratory Precision}

Replicate analyses of individual samples were performed by the ESD RAL to determine laboratory precision. Results from this analysis were evaluated using the DER procedure described previously.

\section{DATA ANALYSIS METHODS}

\subsection{General Summary Approach}

Concentrations (pCi/g dry weight) for ${ }^{137} \mathrm{Cs}$ and ${ }^{60} \mathrm{Co}$ were calculated for each sample. Minimums, maximums, means, and standard deviations of ${ }^{137} \mathrm{Cs}$ and ${ }^{60} \mathrm{Co}$ concentrations were calculated for each study reach and each river mile. Human health risk calculations, described below, were also calculated for each of these areas. 


\section{GIS Approach}

A GIS approach, using two software packages (GRASS and Arc/Info), was used to generate a set of variables that had potential explanatory value for the variability in radionuclide concentrations. Data used in the GRASS portion of the analysis originated from Arc/Info coverages to insure that a common data set was used. However, the GRASS data set was only available for the portion of the reservoir downstream of CRM 1, so some variables were available only for lower Watts Bar. This data set included location of the channel, which was used to obtain distance of each sample from the old river channel (preinundation river boundary), and distance from shore. The methods for obtaining these variables are described more completely in the RI/FS for Lower Watts Bar Reservoir Operable Unit (DOE 1994). Actual river miles and distance from the confluence of White Oak Creek and Clinch River were calculated using Arc/Info routing commands.

The river mile location for each sample calculated from the GIS sometimes differs from that originally recorded because the original river mile was where a sample was planned to be collected based on the navigation chart, and not necessarily were it was collected. Visual interpolation was used to assign river miles to samples during planning, which is an inaccurate method at best. Also, samples were not always collected where they were planned. Sample locations were recorded on the maps in the field and later transferred to a GIS coverage in Arc/Info. Arc/Info event and routing commands were used to generate an accurate river mile variable for actual sample locations.

All GIS-generated variables [sample depth, distance from shore, distance from channel, and distance from White Oak Creek (WOC)] were linked to sample ID numbers in the data base. A series of variance analyses were performed to test the relationships between these and other variables and ${ }^{137} \mathrm{Cs}$ and ${ }^{60} \mathrm{Co}$ concentrations.

\subsection{Statistical Approach}

${ }^{137} \mathrm{Cesium}$ and ${ }^{60} \mathrm{Co}$ concentrations were summarized in three separate ways: by study reach, by river mile, and by above and below the $735-\mathrm{ft} \mathrm{msl}$ water level. This approach will allow comparison of results from this study to those from the CR-ERP Phase 1 study, which used the same reaches, as well as most other studies that generally report data by river miles. In addition, this approach will allow separate evaluation of those sediments exposed during winter.

Initially, a Kolmogorov D statistic was used to test for normality of the distributions of ${ }^{137} \mathrm{Cs}$ and ${ }^{60} \mathrm{Co}$ concentrations. Results of this test and a histogram of the data (Fig. 2.1) indicated that the data were log-normally distributed. Therefore, the ${ }^{137} \mathrm{Cs}$ and ${ }^{60} \mathrm{Co}$ concentration data were log transformed prior to further statistical analysis. Figures 2.1 and 2.2 show the ${ }^{137} \mathrm{Cs}$ concentration distributions before and after log transforming.

Analysis of variance (ANOVA) procedures were performed using SAS to test the explanatory power of several parameters on the variability in ${ }^{137} \mathrm{Cs}$ and ${ }^{60} \mathrm{Co}$ concentrations. These explanatory variables include: sediment type, depth of sample, distance from shoreline, distance from channel, river mile, and the relative distance from White Oak Creek confluence with the Clinch River. Sediment type was treated as a class variable throughout the analysis, and all other variables were treated as continuous. Because the distance from shore, distance from channel, and sample depth, (all calculated by the GIS analyses), were limited to the area 
downstream of CRM 1, the total number of samples available for the models with these variables is smaller than with models that did not include these variables.

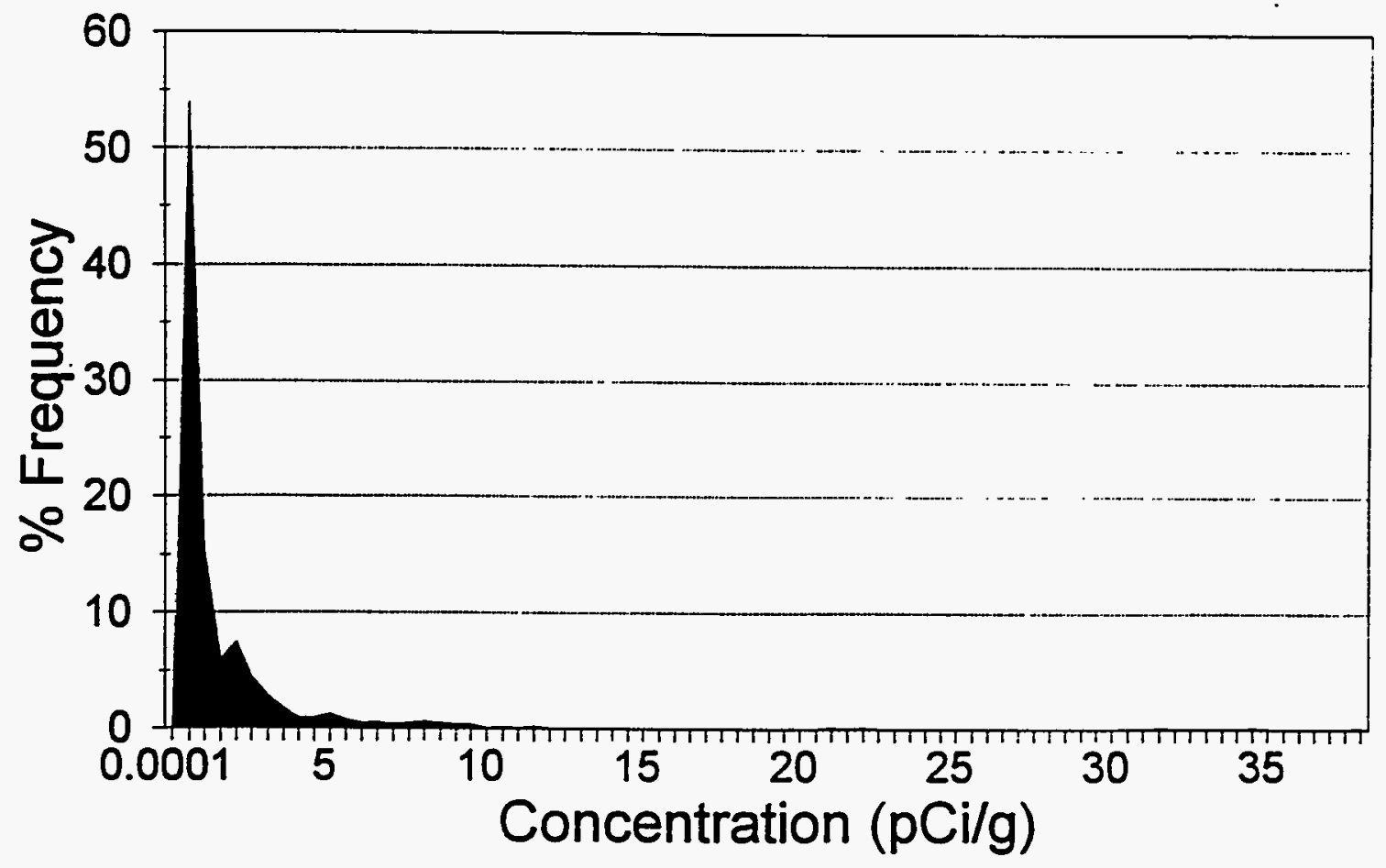

Figure 21. Distribution of ${ }^{137} \mathrm{Cs}$ in surface sediments of WBR.

The ability of field crews to visually identify truly different sediment types was tested. A number of samples collected for the Sediment Transport Modeling Task of the CR-ERP were collected and classified by the same crews that collected samples for the near-shore task. These samples were also analyzed for physical parameters: particle size distribution, total organic carbon, porosity, density, and percent moisture. A statistical cluster analysis was performed using the percentages of sand, silt, and clay fractions for these samples to see how many classes could be distinguished with these data and to compare how these statistically generated classes matched the visual field classification. 


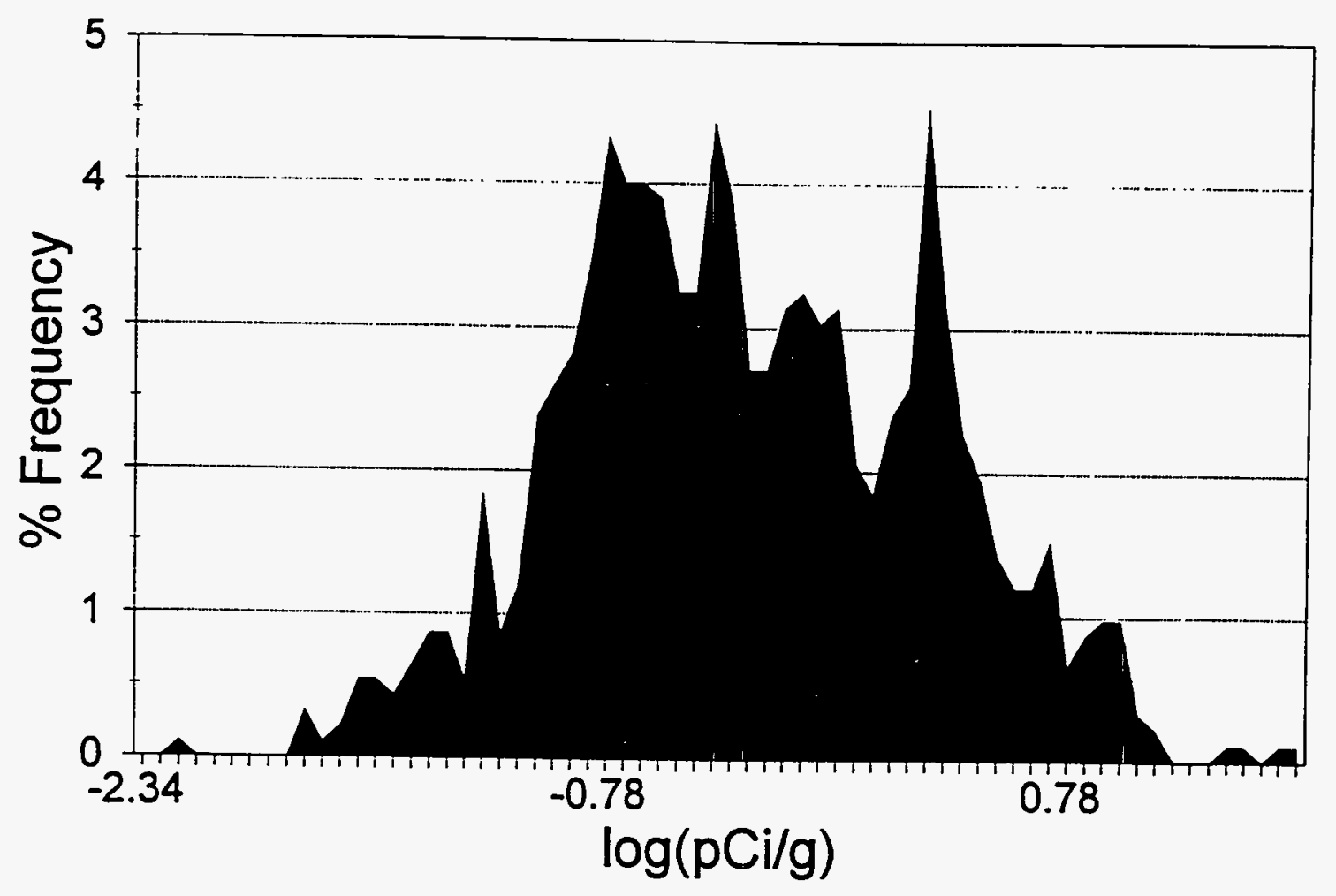

Figure 22 Distribution of log-transformed cesium-137 in surface sediments of WBR.

\subsection{Risk Approach}

Two approaches are used in this report to evaluate human health risk associated with the data collected for this task. First, a simple direct exposure scenario was used as a quick screening tool to decide if more sampling was needed or if a particular permit site evaluated by the WBRIPG posed no significant risk Second, a more complete exposure scenario was employed that included inhalation, ingestion, and direct exposure pathways for near-shore sediments and dredged deep-water sediments. This last methodology is the same used in evaluating human health risk in the Phase 1 Data Summary (ORNL/ER-155) and in the RI/FS for Lower Watts Bar Reservoir (DOE/OR/01-1282\&D1).

The WBRIPG defined $15 \mathrm{pCi} / \mathrm{g}$ as an "action level" concentration for ${ }^{137} \mathrm{Cs}$. This is the concentration at which lifetime risk of excess cancer exceeds $1 \times 10^{-4}$, given a $2000 \mathrm{~h} / \mathrm{year}$ exposure to the contaminated sediment for 30 years. This scenario only includes direct exposure to gamma radiation. Sites with ${ }^{137} \mathrm{Cs}$ above the action level will require additional characterization for permit evaluation. To date, no permits have been refused on the basis of contaminated sediment. Hoffman (pers. comm. 1991) developed an equation to calculate human health risk based on this scenario for both ${ }^{137} \mathrm{Cs}$ and ${ }^{60} \mathrm{Co}$ concentrations in sediment (Appendix A). These equations were applied to each sample and summarized for both study reach and river mile.

The Shoreline Use Scenario and the Dredging Scenario were two exposure scenarios used in the Phase 1 Data Summary, the RI/FS for Lower Watts Bar (DOE/OR/01-1282\&D1) and planned for the RI/FS for the final CR-ERP report that encompassed sediments. The Shoreline Use Scenario considers only those sediments above winter pool $(735 \mathrm{ft} \mathrm{msl})$ because 
these are uncovered by water for part of the year. The exposure pathways for the Shoreline Use Scenario include ingestion of sediment, inhalation of sediment in the form of dust, and external exposure to gamma-emitting radionuclides in the sediment. The Dredging Scenario was previously used to evaluate data from deep-water core samples only. However, it could be used to evaluate risk from near-shore dredged sediments as well. The Dredging Scenario assumes that sediment is removed from the reservoir and deposited on land where it is used to grow crops and support livestock. The sediment is assumed to be spread thick enough so that plowing would not dilute the material by mixing it with the underlying soil. Direct exposure pathways for the Dredging Scenario include ingestion of dredged sediment, inhalation, and external exposure to gamma-emitting radionuclides. Indirect exposures occur via the ingestion of milk, meat, and vegetables produced on the dredged sediment. The only change in the application of the Dredging Scenario for this report is that only the surface sediment (approximately the top $15 \mathrm{~cm}$ ) is assumed to be dredged.

The concentrations of ${ }^{137} \mathrm{Cs}$ and ${ }^{60} \mathrm{Co}$ that would yield a human health risk equivalent to $1 \times 10^{-4}$ for each exposure pathway were determined by back calculation using the risk equations presented in DOE 1994. These values will be compared to concentration summaries in the Results and Discussion section of this report. 


\section{RESULTS AND DISCUSSION}

A total of 926 samples were collected as part of this task Table 3.1 shows the distribution of samples separated by Reach, and Plates 1 and 2 show sample collection sites and relative ${ }^{137} \mathrm{Cs}$ concentrations.

Table 3.1. Number of samples collected in each study reach

\begin{tabular}{cr||cr}
\hline Reach & Number of samples & Reach & Number of samples \\
\hline 1 & 32 & 5 & 496 \\
2 & 166 & 6 & 31 \\
3 & 2 & 10 & 7 \\
4 & 156 & 18 & 36 \\
\hline & & Total 926 \\
\hline
\end{tabular}

Of the 926 samples collected and analyzed for ${ }^{137} \mathrm{Cs}$ and ${ }^{60} \mathrm{Co}$ concentrations, five samples had ${ }^{137} \mathrm{Cs}$ levels below detectable activities and 422 samples had ${ }^{60} \mathrm{Co}$ levels below detectable activities. The concentrations for these samples used to calculate summary statistics by reach and river mile were set to the detection limits for those analyses. Therefore, the ${ }^{60} \mathrm{Co}$ concentration summaries will be biased toward higher concentrations than are actually in the sediments. Because only five samples had ${ }^{137} \mathrm{Cs}$ concentrations below detection, the bias from setting those concentrations to the detection limits will be negligible. To avoid erroneous data interpretation, samples with activities below detection limits were not used in the ANOVA tests.

\subsection{SUMMARY OF ${ }^{137} \mathrm{C}$. CONCENTRATIONS IN SURFACE SEDMMENTS}

\subsubsection{Concentrations By Study Reach}

The average ${ }^{137} \mathrm{Cs}$ concentrations in surface sediments for each study reach are presented, along with standard deviations, minima, and maxima, in Table 3.2 . The highest average ${ }^{137} \mathrm{Cs}$ concentrations are 2.5 to $2.8 \mathrm{pCi} / \mathrm{g}$ and are in Reaches 2 and 4 respectively. The fact that the average ${ }^{137} \mathrm{Cs}$ concentration is higher in Reach 4 than in Reach 2 is initially counterintuitive. One would expect higher concentrations closer to the source. However, deposition of finer particles, which are associated with ${ }^{137} \mathrm{Cs}$, does not occur much in the Clinch River until downstream of the Poplar Creek confluence. Average concentrations in Reach 5 are $0.5 \mathrm{pCi} / \mathrm{g}$, which is about 3.5 times that of the reference area, Reach 10 . These low values in Reach 5 are not unexpected and result from the greater distance from the source and the fact that deposition in the near-shore areas of Reach 5 is dominated by shoreline erosion.

Average concentrations in the three reaches that could be influenced by reverse flows $(3,6$, and, 18) are slightly higher than reference reach concentrations, but all are at or below $1 \mathrm{pCi} / \mathrm{g}$. Reverse flows may have caused small amounts of contaminated sediment to accumulate in these reaches. Most of the samples in these three reaches are within a mile or two of the confluence with the Clinch River. 
Table 3.2 Summaries for ${ }^{137} \mathrm{Cs}$ concentrations in surface sediment for each study reach (Concentrations below detection limits were set to the detection limit.)

\begin{tabular}{crccccr}
\hline $\begin{array}{c}\text { Study } \\
\text { reach }\end{array}$ & N & $\begin{array}{c}\text { Number of } \\
\text { non-detects }\end{array}$ & Mean & $\begin{array}{c}\text { Standard } \\
\text { deviation }\end{array}$ & Minimum & Maximum \\
\hline 1 & 32 & 1 & 0.4371 & 0.4410 & 0.0289 & 1.9501 \\
2 & 166 & 0 & 2.5276 & 4.9808 & 0.0571 & 37.8798 \\
3 & 2 & 0 & 1.2862 & 1.3292 & 0.3464 & 2.2261 \\
4 & 156 & 0 & 2.8900 & 2.8636 & 0.1825 & 21.7993 \\
5 & 496 & 2 & 0.5188 & 0.8270 & 0.0141 & 10.3166 \\
6 & 31 & 0 & 1.0241 & 1.5819 & 0.0054 & 6.8850 \\
10 & 7 & 0 & 0.1377 & 0.0520 & 0.0594 & 0.1995 \\
18 & 36 & 2 & 0.2786 & 0.4446 & 0.0275 & 2.1216 \\
\hline
\end{tabular}

\subsection{Concentrations By River Mile}

Average ${ }^{137} \mathrm{Cs}$ concentrations were summarized by distance from White Oak Creek's confluence with Clinch River (in 1 mile increments) and presented in Fig. 3.1 and Table 1 of Appendix B. (This table also includes standard deviations for means, and minimum and maximum concentrations). ${ }^{137} \mathrm{Cs}$ concentrations average between 1 and $2.5 \mathrm{pCi} / \mathrm{g}$ within the first few miles downstream of White Oak Creek and increase to between 2 and $5.5 \mathrm{pCi} / \mathrm{g}$ over the next 18 miles. The variability in the average ${ }^{137} \mathrm{Cs}$ concentrations in the first 20 miles downstream of WOC probably represents the presence/absence of deposition zones. At 22 miles below White Oak Creek, just downstream of the confluence of the Tennessee and Clinch Rivers, the average ${ }^{137} \mathrm{Cs}$ is $1.5 \mathrm{pCi} / \mathrm{g}$ or less.

This pattern of average concentrations can be explained in several ways. The samples nearest the source would be expected to have higher concentrations than those farther downstream. This could explain the higher averages in the first 22 miles of reservoir compared to the rest of the reservoir. The variability in the average concentration for the first 22 river miles is likely a representation of where deposition zones occur in this section of the river. Lower average concentrations are probably from reaches where little deposition occurs, while reaches with higher averages are likely in areas where deposition occurs. The drop in average ${ }^{137} \mathrm{Cs}$ concentrations at 22 miles from WOC could be a result of dilution from the Tennessee River. The Tennessee River supplies at least ten times as much water and uncontaminated suspended sediment load as the Clinch River to lower WBR. This difference in contributing load would dilute contaminated sediment with sediment not contaminated by ${ }^{137} \mathrm{Cs}$ and result in lower average concentrations. Struxness et al. (1967) and Olsen et al. (1992) concluded that the Clinch River arm of the reservoir acts like a pipe, allowing little deposition to occur, and has transported $80 \%$ of the contaminants into lower WBR. Therefore, although a larger mass of ${ }^{137} \mathrm{Cs}$ entered the lower WBR, ${ }^{137} \mathrm{Cs}$ concentrations are lower because of dilution.

Additionally, several studies, including this one, have demonstrated that the majority of ${ }^{137} \mathrm{Cs}$ and other particle-reactive contaminants are adsorbed onto the sediments in the deep portions of the reservoir, not in the near-shore areas (Olsen et al., 1992, Turner et al., 1985, 
Struxness et al., 1967). More deep-water samples were taken from the Clinch River, proportionally, than from Watts Bar, and because contaminants are preferentially in deep water, this difference in sample stratification may have an effect on this pattern in the results. However, the larger littoral zone in Watts Bar results in a much greater contact zone with shallow water in contrast to the deeper waters in relatively close proximity to the shoreline of the Clinch River. The sampling design used reflects these differences in proximity of deep waters between the two systems, and is also unbiased with respect to distance from shore. Finally, deposition in the near-shore areas of the Clinch River arm is more influenced by upstream sources, while bank erosion processes are the dominant influence in near-shore areas of lower WBR. The resulting pattern portrayed in Fig. 3.1 is most likely caused by a combination of these factors.

There are several locations where maximum ${ }^{137} \mathrm{Cs}$ concentrations in surface sediments are above $10 \mathrm{pCi} / \mathrm{g}$. These are at CRM 1, 10, 13, 15, 18, and 20 (Appendix B, Table 1). The highest of these values is $37 \mathrm{pCi} / \mathrm{g}$ (at CRM 13). The maximum ${ }^{137} \mathrm{Cs}$ concentration in surface sediments in lower WBR does not exceed $3.5 \mathrm{pCi} / \mathrm{g}$ (Appendix B, Table 1).

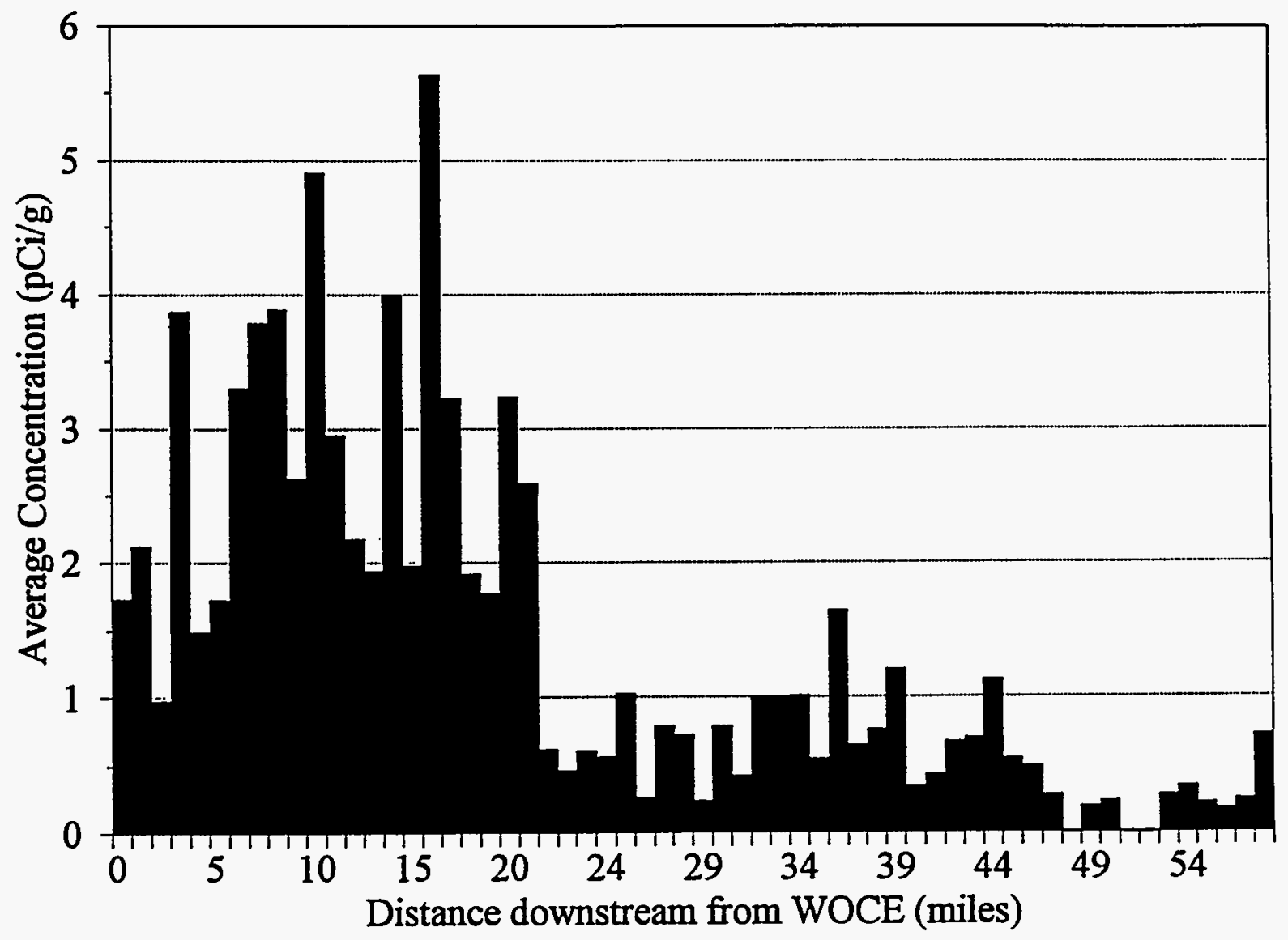

Figure 3.1. Mean cesium-137 concentrations relative to distance downstream from WOCE 


\subsection{ANOVAs}

A statistical approach was employed to develop predictive models of where contaminants are depositing. A successful model would aid in extrapolating contaminant data from individual points to the entire bottom surface of the reservoir by using physical data that is available for the entire reservoir bottom. Additionally, a successful model would aid in identifying critical areas that need to be characterized through sampling.

Sediment type, perpendicular distance from the old river channel, and sample depth were all statistically significant in explaining variability in ${ }^{137} \mathrm{Cs}$ (Table 3.3). The finer sediment types (soft mud and cohesive mud) result in higher ${ }^{137} \mathrm{Cs}$ concentrations than sand and gravel. Samples in the old river channel and in deep water typically have higher ${ }^{137} \mathrm{Cs}$ concentrations. The model that included these variables only used data downstream of CRM 1. The explanatory power of these variables confirms conclusions made in prior studies. Olsen et al. (1992) and Morton et al. (1962) had shown that higher ${ }^{137} \mathrm{Cs}$ concentrations were associated with deep-water sediments near or in the channel and that these are typically sediments with a high percentage of finer particles. Struxness et al. (1967) also demonstrated that ${ }^{137} \mathrm{Cs}$ was preferentially associated with finer particles in sediment.

Table 33. Results of ANOVA for explaining variability of ${ }^{137} \mathrm{Cs}$ concentrations in surface sediment samples collected downstream of CRM 1

Overall model R-square $=0.43, \mathrm{p}<0.0001$, total degrees of freedom $=474$.

\begin{tabular}{lcrrrr}
\hline Source & $\begin{array}{c}\text { Degrees of } \\
\text { freedom }\end{array}$ & $\begin{array}{c}\text { Type III sum } \\
\text { of squares }\end{array}$ & $\begin{array}{c}\text { Mean } \\
\text { square }\end{array}$ & F value & PR > F \\
\hline Sediment type & 4 & 22.4460 & 5.6115 & 35.21 & 0.0001 \\
Depth & 1 & 4.3306 & 4.3306 & 27.18 & 0.0001 \\
Distance from land & 1 & 0.2111 & 0.2111 & 1.33 & 0.2503 \\
Distance from channel & 1 & 11.6334 & 11.6334 & 73.01 & 0.0001 \\
\hline
\end{tabular}

There was an expected, significant, non-additive interaction between depth and sediment type. Models including a variable representing this interaction did not improve the predictive ability of the model. Plots of residuals versus model results versus independent variables reveal no perceivable trends. This suggests that there is no bias between model results and the level of ${ }^{137} \mathrm{Cs}$ and the values for the independent variables.

Additional evidence of the effect of depth on ${ }^{137} \mathrm{Cs}$ concentrations is shown in Table 3.4., which presents concentrations summarized for areas between the winter and summer pool elevations and for those areas below the winter pool elevations for samples where depth estimates are available. Average concentrations in the areas above winter pool for all reaches are lower than average concentrations below the winter pool elevation. There was a statistically significant difference for above and below winter pool concentrations for Reach 5 only $\left(t_{\text {crit }}\right.$ df $\left.=432=1.96, \alpha=0.05\right)$. Also, maximum concentrations are always higher in the deeper water, except for Reach 6 . Wave action in the near-shore area effectively causes winnowing of the shoreline sediments by washing loose fine-grained material into the deeper water and eroding the local bank. The standard deviations generally decrease with distance 
downstream, as represented by reach. This suggests that deposition, and therefore ${ }^{137} \mathrm{Cs}$ concentration, is highly variable near WOC and becomes more uniform with distance.

Table 3.4. Summary of ${ }^{17} \mathrm{Cs}$ concentrations in surface sediments above and below $735 \mathrm{ft}$. msl, by reach

\begin{tabular}{crrccc}
\hline \multicolumn{6}{c}{ Above 735 } \\
\hline Reach & N & Mean & $\begin{array}{c}\text { Standard } \\
\text { deviation }\end{array}$ & Minimum & Maximum \\
\hline 2 & 44 & 2.12 & 2.27 & 0.26 & 11.13 \\
4 & 47 & 1.94 & 1.81 & 0.23 & 8.19 \\
5 & 205 & 0.27 & 0.24 & 0.01 & 1.29 \\
6 & 19 & 0.68 & 1.53 & 0.01 & 6.88 \\
\hline & & & Below 735 & & \\
\hline & & & Standard & & \\
Reach & $\mathrm{N}$ & Mean & deviation & Minimum & Maximum \\
\hline 2 & 122 & 2.67 & 5.65 & 0.06 & 37.88 \\
4 & 100 & 3.34 & 3.23 & 0.18 & 21.79 \\
5 & 229 & 0.80 & 1.11 & 0.01 & 10.31 \\
6 & 12 & 1.56 & 1.58 & 0.23 & 5.18 \\
\hline
\end{tabular}

An ANOVA model that included all Clinch River and Tennessee River samples showed that sediment type and relative distance from the confluence of White Oak Creek and Clinch River were useful explanatory parameters for variability in ${ }^{137} \mathrm{Cs}$ concentrations (overall model $\mathbf{R}^{2}=0.35, p<0.0001, \mathrm{df}=800$ ) (Table 3.5). Consideration of sediment type and distance from the source (WOCE) explains $35 \%$ of the variation observed in ${ }^{137} \mathrm{Cs}$ concentrations in surface sediments. The statistical significance of these relationships confirms the assumptions used in Remedial Investigation/Feasibility Study Report for Lower Watts Bar Reservoir Operable Unit (DOE, 1994) in which a probabilistic map of ${ }^{137} \mathrm{Cs}$ distribution in lower Watts Bar sediments was developed using sediment type, distance from channel, distance downstream from the source, and water depth as the predictive variables.

Table 35. Results of ANOVA for explaining variability of ${ }^{177} \mathrm{Cs}$ concentrations in the samples from the Clinch River and lower WBR

Overall model R-square $=0.35, p<0.0001$, total degrees of freedom $=800$.

\begin{tabular}{lccrrrr}
\hline Source & $\begin{array}{c}\text { Degrees of } \\
\text { freedom }\end{array}$ & $\begin{array}{c}\text { Type III sum } \\
\text { of squares }\end{array}$ & Mean square & F Value & PR > F \\
\hline Sediment type & 4 & 18.3593 & 4.5898 & 18.87 & 0.0001 \\
Distance from WOCE & 1 & 90.1928 & 90.1928 & 370.72 & 0.0001 \\
\hline
\end{tabular}




\subsubsection{Human Health Risk: ${ }^{137} \mathrm{Cs}$}

Human health risks from exposure to ${ }^{137} \mathrm{Cs}$ in surface sediments were assessed by comparing concentrations of sediment samples to the concentrations that would result in a $1 \times 10^{-4}$ risk of cancer under both methods used by the CR-ERP. The screening method used by the WBRIPG used external exposure only, while the two scenarios to be used for the baseline risk assessment included multiple pathways. The fact that the data being discussed represent only the top $10-15 \mathrm{~cm}$ of sediment must be kept in mind when evaluating risk using these scenarios and pathways.

\section{Screening Method}

The concentration of ${ }^{137} \mathrm{Cs}$ determined to yield a $1 \times 10^{-4}$ excess risk of cancer by Hoffman (Appendix A) and used by the WBRIPG was determined to be $15 \mathrm{pCi} / \mathrm{g}$. Comparing this value to the ${ }^{137} \mathrm{Cs}$ concentration averages for each reach (Table 3.2) and each river mile (Appendix B, Table 1) shows that the critical value was never exceeded by the average concentration. Nor was the critical value exceeded by mean ${ }^{137} \mathrm{Cs}$ concentrations above or below the winter pool elevations for any of Reaches $2,4,5$, or 6 (Table 3.4). In fact, no samples anywhere in Reaches 5 or 6, or in Reaches 2 or 4 above $735 \mathrm{ft}$ msl, exceeded the threshold of concern. There are 4 river miles in the Clinch River where the maximum concentration does exceed the 15-pCi/g level; CRM 11, 13, 18, and 20 (Appendix B, Table 1). A review of field logbooks indicates that these samples were all below $735 \mathrm{ft}$ msl. The actual human health risks associated with the average ${ }^{137} \mathrm{Cs}$ concentration for each river mile are presented in Appendix B Table 2.

The WBRIPG evaluated the data that were available in January 1992. As a result of this evaluation, the area of concern to the WBRIPG was restricted to areas below the winter pool elevation (735 ft msl) up to and including the Emory River and all areas within the Clinch River arm from CRM 4.3 upstream to Melton Hill Dam. The change in sampling design late in the project (targeting deeper water in embayments off of the main channel and areas immediately downstream of White Oak Creek) was directed at the areas of the reservoir not covered previously to examine more of the reservoir within the area of concern to the WBRIPG.

\section{Baseline Risk Assessment Method}

The ${ }^{137} \mathrm{Cs}$ concentrations in sediment that would result in a cancer risk of $1 \times 10^{-4}$ for the scenarios and pathways to be used in the baseline risk assessment are presented in Table 3.6. The external exposure pathway concentration, $11.5 \mathrm{pCi} / \mathrm{g}$, is close to the $15 \mathrm{pCi} / \mathrm{g}$ used by the WBRIPG. Importantly, this is the lowest concentration for any pathway that results in a $1 \times 10^{-4}$ risk. Therefore, the external exposure pathway dominates buman health risk scenarios. This supports the WBRIPG's decision to use only the external exposure scenario and the 15-pCi/g value. 
Table 3.6. Sediment ${ }^{137} \mathrm{C}$ concentration that would produce a $1 \times 10^{4}$ cancer risk based on parameter values and equations used in RIFS for lower WBR

\begin{tabular}{llc}
\hline Pathway & Relevant scenarios & $\begin{array}{c}{ }^{137} \mathrm{Cs} \text { concentration } \\
(\mathrm{pCi} / \mathrm{g})\end{array}$ \\
\hline External & Dredging and In-Place & 11.5 \\
Ingestion & Dredging and In-Place & 3402.0 \\
Inhalation & Dredging and In-Place & $1,865,700.0$ \\
Meat & Dredging only & 80.73 \\
Milk & Dredging only & 54.0 \\
Vegetables & Dredging only & 564.3 \\
\hline
\end{tabular}

The one-mile river reaches whose maximum concentrations exceeded $11.5 \mathrm{pCi} / \mathrm{g}$ are the same as those that exceeded $15 \mathrm{pCi} / \mathrm{g}$. No additional samples reached this level; however several were close (CRM 0, 10, 15, and 16). Potential health risks associated with pathways other than external exposure are insignificant given the relatively high critical values and comparatively low concentrations that were measured in the field.

The overall human health risks associated with ${ }^{137} \mathrm{Cs}$ concentrations in surface sediment are below $1 \times 10^{-4}$ if the sediment is left in place. In only a few isolated areas (areas within CRM 0,10,15, and 16) would surface sediment concentrations of ${ }^{137} \mathrm{Cs}$ result in a human health risk exceeding $1 \times 10^{-4}$ using the Dredging Scenario.

\subsection{SUMMARY OF ${ }^{60} \mathrm{Co}$ CONCENTRATIONS IN SURFACE SEDIMENTS}

Nearly half of the surface sediment samples (416 of 924) had ${ }^{60} \mathrm{Co}$ activities below detection limits. Detection limits are well below concentrations determined to be a health risk. This indicates that, in general, ${ }^{60} \mathrm{Co}$ is not a concern in the off-site environment. The low concentrations of ${ }^{60} \mathrm{Co}$ are probably due to the smaller amount of ${ }^{60} \mathrm{Co}$ released to the off-site environment and to the 5-year half-life of ${ }^{60} \mathrm{Co}$. The peak release of gamma-emitting radionuclides, including ${ }^{60} \mathrm{Co}$, was during the mid-1950s, allowing approximately 6 half-lives to occur between release and when these samples were collected in this study. This natural decay process accounts for a loss of $98 \%$ of the original activity from ${ }^{60} \mathrm{Co}$.

\section{Concentrations By Reach}

The average ${ }^{60} \mathrm{Co}$ concentrations for each study reach are presented, along with standard deviations, minima, and maxima, in Table 3.7. By far, the highest average ${ }^{60} \mathrm{Co}$ concentration is in Reach 1. This high ${ }^{60} \mathrm{Co}$ average in Reach 1 is a result of sampling downstream of the former American Nuclear Corporation (ANC) site on Braden Branch across from Oak Ridge Marina. The high ${ }^{60} \mathrm{Co}$ concentrations here are a result of releases from the ANC facility and are not related to DOE activities. A separate summary of the Braden Branch data and other historical data is provided in Appendix C. Average concentrations in all other reaches are within background levels. 
Reach 4 has the second highest average ${ }^{60} \mathrm{Co}$ concentration after Reach 1 , followed by Reach 2. As with ${ }^{137} \mathrm{Cs},{ }^{60} \mathrm{Co}$ is particle reactive and is preferentially associated with finer sediment particles. Finer sediments do not start depositing in significant quantities in the Clinch River until downstream of the Poplar Creek confluence. This explains the similarity of the pattern to ${ }^{137} \mathrm{Cs}$ average concentrations.

Table 3.7. Summary of ${ }^{\infty} \mathrm{Co}$ concentrations for each study reach (Concentration values for samples with ${ }^{\circ} \mathrm{Co}$ concentrations below detection limits were set to the detection limits.)

\begin{tabular}{rrrrrrr}
\hline Reach & N & $\begin{array}{c}\text { Number of } \\
\text { non-detects }\end{array}$ & Mean & $\begin{array}{c}\text { Standard } \\
\text { deviation }\end{array}$ & Minimum & Maximum \\
\hline 1 & 32 & 2 & 1.7382 & 2.8226 & 0.0233 & 9.0599 \\
2 & 166 & 37 & 0.0878 & 0.0713 & 0.0146 & 0.5250 \\
3 & 2 & 0 & 0.0740 & 0.0866 & 0.0127 & 0.1352 \\
4 & 156 & 7 & 0.1315 & 0.0978 & 0.0219 & 0.5173 \\
5 & 496 & 323 & 0.0345 & 0.0318 & 0.0024 & 0.2713 \\
6 & 30 & 15 & 0.0520 & 0.0661 & 0.0014 & 0.2639 \\
10 & 7 & 7 & 0.0191 & 0.0091 & 0.0063 & 0.0276 \\
18 & 36 & 31 & 0.0231 & 0.0189 & 0.0047 & 0.0987 \\
\hline
\end{tabular}

\section{Concentrations By River Mile}

The pattern of average ${ }^{60} \mathrm{Co}$ concentration for each river mile downstream from WOCE is similar to the pattern for ${ }^{137} \mathrm{Cs}$ (Fig. 3.2). Concentrations are generally higher in the first 20 miles, with several peaks approaching $0.2 \mathrm{pCi} / \mathrm{g}$ (near 7 and 16 miles downstream from White Oak Creek) and a quick drop downstream from the confluence of the Clinch and Tennessee Rivers. The variability in average concentrations within the first 20 miles probably represents the presence and absence of deposition zones. The pattern of average ${ }^{60} \mathrm{Co}$ concentrations matches that of ${ }^{137} \mathrm{Cs}$, although the ${ }^{60} \mathrm{Co}$ concentration peaks are smaller due to the differences in half-lives.

\section{ANOVAS}

As with ${ }^{137} \mathrm{Cs}$, sediment type, distance from the old river channel, and sample depth were all significant in explaining variability in ${ }^{60} \mathrm{Co}$ (all $\mathrm{Pr}>\mathrm{F}=0.0001, \mathrm{R}^{2}=0.37$.) (Table 3.8). The model that included these variables only used data downstream of CRM 1. Again, these results confirm those of Olsen et al. (1992), Morgan et al. (1962), Struxness et al. (1967). 


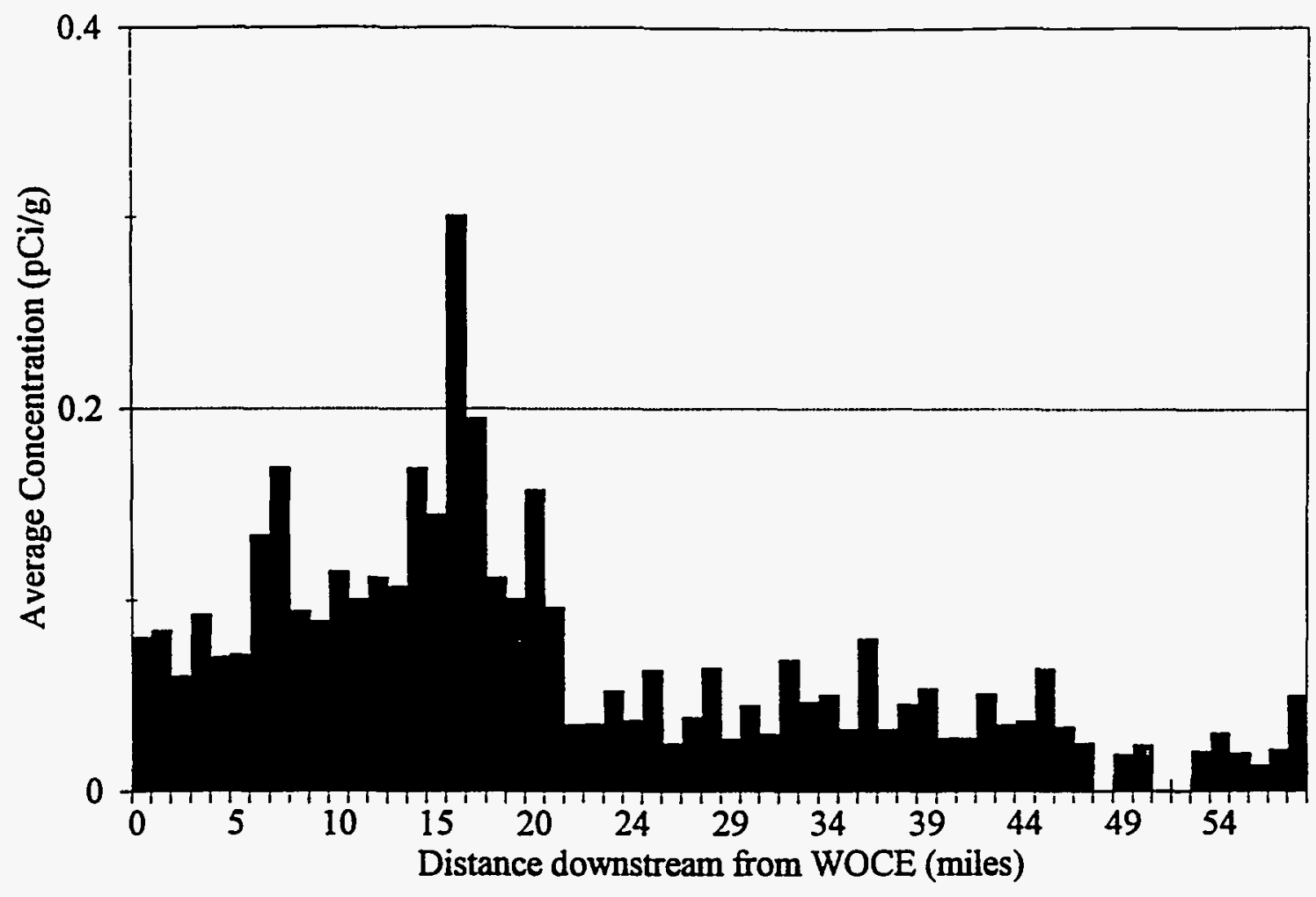

Figure 3.2 Mean cobalt-60 concentrations relative to distance downstream from WOCE

Table 3.8. Results of ANOVA for explaining variability of ${ }^{\infty} \mathrm{Co}$ concentrations in samples from downstream of CRM 1

Overall model $R$-square $=0.37, p<0.0001$, total degrees of freedom $=435$.

\begin{tabular}{lccrrr}
\hline Source & $\begin{array}{c}\text { Degrees of } \\
\text { freedom }\end{array}$ & $\begin{array}{c}\text { Type III } \\
\text { sum of } \\
\text { squares }\end{array}$ & $\begin{array}{c}\text { Mean } \\
\text { square }\end{array}$ & F value & PR > F \\
\hline Sediment type & 4 & 3.1906 & 0.7976 & 9.54 & 0.0001 \\
Depth & 1 & 1.9682 & 4.3306 & 23.55 & 0.0001 \\
Distance from land & 1 & 0.2056 & 0.2056 & 2.46 & 0.2503 \\
Distance from channel & 1 & 6.0496 & 6.0496 & 72.39 & 0.0001 \\
\hline
\end{tabular}

There were two sets of significant non-additive interactions between independent variables for the ${ }^{60} \mathrm{Co}$ model. As in the ${ }^{137} \mathrm{Cs}$ model, sediment type and depth had a significant interaction. Depth and distance from land also displayed a significant interaction. However, there was no improvement in model performance when both interaction variables were included. Scatter plots of residuals versus model results and independent variables showed no trends. This suggests that there is no bias to model predictions within the range of the observed ${ }^{60} \mathrm{Co}$ concentrations and the range of values in the independent variables.

Additional evidence for the effect of depth on ${ }^{60} \mathrm{Co}$ concentrations is shown in Table 3.9, which presents the data summarized by those areas between the winter and summer pool elevations and for those below the winter pool elevations. The maximum for each reach above 
winter pool is lower than the maximum concentrations below winter pool in each reach. However, there is no apparent difference between average concentrations in the area below winter pool and the average concentrations above the winter pool elevation. The pattern of deep versus shallow ${ }^{60} \mathrm{Co}$ concentrations is not as marked as with ${ }^{137} \mathrm{Cs}$. This is probably due to the overall low values of ${ }^{60} \mathrm{Co}$ throughout the system.

Table 3.9. Summary of ${ }^{\infty} \mathrm{Co}$ concentrations above and below $735 \mathrm{ft}$ msl, by reach

\begin{tabular}{cccccc}
\hline \multicolumn{6}{c}{ Above 735 ft } \\
\hline Reach & $\mathrm{N}$ & Mean & $\begin{array}{c}\text { Standard } \\
\text { deviation }\end{array}$ & Minimum & Maximum \\
\hline 2 & 44 & 0.08 & 0.05 & 0.01 & 0.30 \\
4 & 47 & 0.11 & 0.08 & 0.02 & 0.43 \\
5 & 205 & 0.03 & 0.01 & $<0.01$ & 0.13 \\
6 & 18 & 0.04 & 0.06 & $<0.01$ & 0.26 \\
\hline & \multicolumn{5}{c}{ Below 735 ft } \\
\hline & & & Standard & \\
\hline Reach & N & Mean & deviation & Minimum & Maximum \\
\hline 2 & 122 & 0.09 & 0.07 & 0.01 & 0.52 \\
4 & 102 & 0.14 & 0.10 & 0.02 & 0.51 \\
5 & 229 & 0.04 & 0.04 & $<0.01$ & 0.27 \\
6 & 12 & 0.06 & 0.07 & 0.01 & 0.26 \\
\hline
\end{tabular}

Sediment type and relative distance downstream from WOCE are important parameters in explaining variance in ${ }^{60} \mathrm{Co}$ concentrations in the Clinch River and lower WBR (Table 3.10). The ANOVA model that includes these 2 parameters only accounts for $24 \%$ of the variability. Therefore, other parameters are also important in distributing ${ }^{60} \mathrm{Co}$ throughout the system. Transect sampling in lower WBR demonstrated that localized bathymetric depressions that are relatively small can effectively trap sediment. This means that even if water is shallow, a pool-like depression of only a few meters will trap sediment. The opposite is also true: a hump in a deep-water area will be erosion zone. Including this type of fine-scale topographic information in the analysis might improve explanatory power of the ANOVA model. 
Table 3.10. Results of ANOVA for explaining variability of ${ }^{\circ} \mathrm{Co}$ concentrations in the samples from the Clinch River and lower WBR

Overall model R-square $=0.24, p<0.0001$, total degrees of freedom $=435$.

\begin{tabular}{lcrrrr}
\hline Source & $\begin{array}{c}\text { Degrees of } \\
\text { freedom }\end{array}$ & $\begin{array}{c}\text { Type III } \\
\text { sum of } \\
\text { squares }\end{array}$ & $\begin{array}{c}\text { Mean } \\
\text { square }\end{array}$ & F value & PR > F \\
\hline Sediment type & 4 & 3.2416 & 0.8103 & 8.07 & 0.0001 \\
Distance from WOCE & 1 & 12.4610 & 12.4610 & 124.04 & 0.0001 \\
\hline
\end{tabular}

\section{Human Health Risk}

\section{Screening Method}

The concentration of ${ }^{60} \mathrm{Co}$ that was determined by Hoffman (Appendix A) to yield a $1 \times 10^{-4}$ excess risk of cancer was also determined to be $15 \mathrm{pCi} / \mathrm{g}$. Comparing this value to the ${ }^{60} \mathrm{Co}$ concentration averages for each reach (Table 3.2) and river mile (Appendix B, Table 3) shows that the critical value was never exceeded by the average or maximum concentration. In fact, this critical threshold for ${ }^{60} \mathrm{Co}$ concern was never approached or exceeded by any single sample in Watts Bar Reservoir during the near-shore sediment characterization. Actual risks associated with ${ }^{60} \mathrm{Co}$ average concentrations for each river mile are presented in Appendix B, Table 4.

\section{Baseline Risk Assessment Method}

The ${ }^{60} \mathrm{Co}$ concentrations in sediment that would result in a cancer risk of $1 \times 10^{-4}$ for the scenarios and pathways to be used in the baseline risk assessment are presented in Table 3.11. Note that the external exposure pathway concentration, $7.3 \mathrm{pCi} / \mathrm{g}$, is about half that of the 15-pCi/g concentration used in the screening method. This difference is likely a result of the different methods used to account for radioactive decay. As with the ${ }^{137} \mathrm{Cs}$ baseline risk calculations, the external exposure pathway is the most important. The average ${ }^{60} \mathrm{Co}$ concentrations for each reach and river mile are all below the 7.3-pCi/g critical level, except for several samples in Reach 1. These samples were collected from the Braden Branch area and are not associated with DOE activities.

Table 3.11. Sediment ${ }^{\infty} \mathrm{Co}$ concentrations that would produce a $1 \times 10^{-4}$ cancer risk based on parameter values and equations used in the RI/FS for lower WBR

\begin{tabular}{llc}
\hline Pathway & Relevant scenarios & $\begin{array}{c}{ }^{\infty} \mathrm{Co} \text { concentration } \\
(\mathrm{pCi} / \mathrm{g})\end{array}$ \\
\hline External & Dredging and In-Place & 7.3 \\
Ingestion & Dredging and In-Place & 6245.0 \\
Inhalation & Dredging and In-Place & $236,250.0$ \\
Meat & Dredging only & 151.0 \\
Milk & Dredging only & 405.0 \\
Vegetables & Dredging only & 1053.0 \\
\hline
\end{tabular}




\subsection{SEIDIMENT CLASSIFICATION ANALYSIS}

Results of the statistical cluster analysis of particle size class proportions are presented in Tables 3.12 and 3.13. The analysis demonstrates that the percent sand, silt, and clay fractions contain enough information to distinguish three or four distinct sediment types. Tables 3.12 and 3.13 show the particle size breakdowns for each class for the three-category and four-category analysis respectively.

Table 3.12. Particle size ranges for each class in the three-category cluster analysis

\begin{tabular}{lccrrr}
\hline Variable & N & Mean & $\begin{array}{l}\text { Standard } \\
\text { deviation }\end{array}$ & Minimum & Maximum \\
\hline \multicolumn{7}{c}{ Cluster 1 } \\
\hline Clay & 12 & 18.9 & 8.6 & 7.0 & 36.0 \\
Silt & 12 & 62.1 & 3.3 & 56.0 & 67.0 \\
Sand & 12 & 18.9 & 8.2 & 6.0 & 31.0 \\
\hline \multicolumn{7}{c}{ Cluster 2 } \\
\hline Clay & 10 & 9.9 & 2.2 & 6.0 & 13.0 \\
Silt & 10 & 39.9 & 7.1 & 32.0 & 51.0 \\
Sand & 10 & 50.2 & 7.4 & 36.0 & 58.0 \\
\hline \multicolumn{7}{c}{ Cluster 3 } \\
\hline Clay & 8 & 5.9 & 2.0 & & \\
Silt & 8 & 22.3 & 5.9 & 14.0 & 32.0 \\
Sand & 8 & 72.3 & 7.2 & 63.0 & 84.0 \\
\hline
\end{tabular}


Table 3.13. Particle size ranges for each class in the four-category cluster analysis

\begin{tabular}{|c|c|c|c|c|c|}
\hline Variable & $\mathbf{N}$ & Mean & $\begin{array}{l}\text { Standard } \\
\text { deviation }\end{array}$ & Minimum & Maximum \\
\hline \multicolumn{6}{|c|}{ Cluster 1} \\
\hline Clay & 3 & 31.7 & 8.0 & 28.0 & 36.0 \\
\hline Silt & 3 & 61.0 & 4.4 & 56.0 & 64.0 \\
\hline Sand & 3 & 7.3 & 1.2 & 6.0 & 8.0 \\
\hline \multicolumn{6}{|c|}{ Cluster 2} \\
\hline Clay & 9 & 14.7 & 4.1 & 7.0 & 20.0 \\
\hline Silt & 9 & 62.4 & 3.1 & 58.0 & 67.0 \\
\hline Sand & 9 & 22.8 & 4.9 & 16.0 & 31.0 \\
\hline \multicolumn{6}{|c|}{ Cluster 3} \\
\hline Clay & 10 & 9.9 & 2.2 & 6.0 & 13.0 \\
\hline Silt & 10 & 39.9 & 7.1 & 32.0 & 51.0 \\
\hline Sand & 10 & 50.2 & 7.4 & 36.0 & 58.0 \\
\hline \multicolumn{6}{|c|}{ Cluster 4} \\
\hline Clay & 8 & 5.9 & 2.0 & 4.0 & 9.0 \\
\hline Silt & 8 & 22.3 & 5.9 & 14.0 & 32.0 \\
\hline Sand & 8 & 72.3 & 7.2 & 63.0 & 84.0 \\
\hline
\end{tabular}

The visual classification used five categories to classify sediment type, but the statistical methods could only detect three or four different categories (Table 3.14). Only one sample for two sediment type categories (sand and gravel and submerged soil) was available for statistical analysis. The gravel sample was omitted because particle size analysis data were not available. The submerged soil sample was statistically categorized into Cluster 1 in both systems, which indicates a high clay content. Field samples of hard-packed clay are visually characterized as submerged soil and would be expected to have a high clay percentage when analyzed for particle size distribution.

With few differences, the visual classification system compares well with either the threeor four-category statistical method (Table 3.14). The ability of the visual sediment classification to match the clustered textural analysis appears dependent on the ability to determine the presence of sand particles. In codifying the visual description, which was often a combination of several sediment types, a decision had to be made as to which sediment type to select for entry in the data base. In all cases where there were compound descriptions of sediment type in the field logbook, the first description was entered in the data base. The additional information from the logbook (shown parenthetically in Table 3.14) would have improved the visual classification scheme. 
Table 3.14. Comparison of visual/physical and statistical sediment type classification schemes

\begin{tabular}{|c|c|c|c|c|}
\hline Sample ID & Visual classification & $\begin{array}{l}\text { Visual } \\
\text { classification } \\
\text { code }\end{array}$ & $\begin{array}{l}\text { Three- } \\
\text { category } \\
\text { clustered } \\
\text { classes }\end{array}$ & $\begin{array}{c}\text { Four- } \\
\text { category } \\
\text { clustered } \\
\text { classes }\end{array}$ \\
\hline 137600 & Cohesive mud & 2 & 1 & 1 \\
\hline 137700 & Cohesive mud & 2 & 1 & 1 \\
\hline 137800 & Soft mud (with sand) & 1 & 1 & 2 \\
\hline 137900 & Sandy mud & 3 & 2 & 3 \\
\hline 138000 & Soft mud & 1 & 1 & 2 \\
\hline 138100 & Sandy mud & 3 & 3 & 4 \\
\hline 138200 & Sandy mud & 3 & 3 & 4 \\
\hline 138300 & Sandy mud & 3 & 2 & 3 \\
\hline 138400 & Sandy mud & 3 & 2 & 3 \\
\hline 138500 & Cohesive mud & 2 & 2 & 3 \\
\hline 138600 & Sandy mud & 3 & 3 & 4 \\
\hline 138700 & Cohesive mud & 2 & 1 & 2 \\
\hline 138800 & Cohesive mud & 2 & 1 & 2 \\
\hline 138900 & Cohesive mud & 2 & 1 & 2 \\
\hline 139000 & Cohesive mud & 2 & 1 & 2 \\
\hline 139100 & Cohesive mud & 2 & 1 & 2 \\
\hline 139200 & Cohesive mud & 2 & 1 & 2 \\
\hline 139300 & Cohesive mud & 2 & 1 & 2 \\
\hline 139700 & Sandy mud & 3 & 3 & 4 \\
\hline 139800 & Soft mud (with sand) & 1 & 2 & 3 \\
\hline 139900 & Soft mud & 1 & 3 & 4 \\
\hline 140000 & Cohesive mud (with sand) & 2 & 3 & 4 \\
\hline 140100 & Soft mud & 1 & 3 & 4 \\
\hline 140200 & Cohesive mud & 2 & 2 & 3 \\
\hline 140300 & Cohesive mud (with sand) & 2 & 2 & 3 \\
\hline 140400 & Cohesive mud (with sand) & 2 & 2 & 3 \\
\hline 140500 & Gravel & 4 & omitted & omitted \\
\hline 140600 & Sandy mud & 3 & 3 & 4 \\
\hline 140700 & Sandy mud (over soft mud) & 3 & 2 & 3 \\
\hline 140800 & Sandy mud (over soft mud) & 3 & 2 & 3 \\
\hline 140900 & Submerged soils (clay) & 5 & 1 & 1 \\
\hline
\end{tabular}

\subsection{QUALITY CONTROL ANALYSIS}

\subsubsection{Sampling Methods}

The DERs calculated from field splits are presented in Table 3.15. Cesium-137 concentrations are below 1 in 35 of the 42 DERs, indicating the homogenization process was usually, but not always, complete. A series of samples/split pairs (from sample IDs 108000B to $116800 \mathrm{~B}$ ) has DERs greater than 1 . All these samples have relatively higher concentrations, suggesting that careful homogenization is more important when concentrations are higher. The concentrations for sample pairs with DERs greater than 1 were all close enough that the risk levels never approached critical regulatory levels for either the regular 
sample or the split sample. This indicates that if concentrations are high enough to exceed regulatory limits, multiple samples should be collected to minimize uncertainty.

All but one of the DERs for ${ }^{60} \mathrm{Co}$ concentrations were 1 or less. DERs were not calculated for all ${ }^{60} \mathrm{C} 0$ pairs because concentrations were below detection limits. There is no apparent relationship between adequacy of homogenization for ${ }^{137} \mathrm{Cs}$ and ${ }^{60} \mathrm{Co}$. 
Table 3.15. DERs for radionuclide concentrations of field splits of sediment grabs

\begin{tabular}{|c|c|c|c|c|c|}
\hline Sample ID & Split ID & $\begin{array}{c}{ }^{137} \mathrm{Cs} \\
\text { concentration } \\
\text { pCi/g }\end{array}$ & $\begin{array}{l}{ }^{137} \mathrm{Cs} \\
\mathrm{DER}\end{array}$ & $\begin{array}{c}{ }^{\infty} \mathrm{Co} \\
\text { concentration } \\
\text { pCi/g }\end{array}$ & $\begin{array}{l}{ }^{60} \mathrm{Co} \\
\mathrm{DER}\end{array}$ \\
\hline 72400 & 72500 & 3.1074 & 0.0474 & 0.1414 & 0.2030 \\
\hline 73300 & 73400 & 0.1067 & 0.2701 & 0.0148 & \\
\hline 74600 & 74700 & 0.0870 & 0.0292 & & \\
\hline 75500 & 75600 & 2.0708 & 0.1954 & 0.1361 & \\
\hline 76500 & 76600 & 0.3507 & 0.8429 & 0.0226 & \\
\hline 77800 & 77900 & 0.2614 & 0.3308 & 0.0189 & \\
\hline 79700 & 79800 & 2.3789 & 0.0683 & 0.1126 & 0.2062 \\
\hline 80700 & 80800 & 0.1538 & 0.3112 & 0.0093 & \\
\hline 81700 & 81800 & 0.7242 & 0.4028 & 0.0521 & \\
\hline 83900 & 84000 & 0.8861 & 0.2461 & 0.0616 & 0.1562 \\
\hline 84700 & 84800 & 1.9652 & 0.5740 & 0.0910 & 0.1426 \\
\hline 87500 & 87600 & 0.1747 & 0.0067 & 0.0253 & \\
\hline 88700 & 88800 & 0.2465 & 0.1279 & 0.0263 & \\
\hline 89500 & 89600 & 0.1337 & 1.0744 & 0.0199 & \\
\hline 91100 & 91200 & 0.3466 & 0.3863 & 0.0255 & \\
\hline 92100 & 92200 & 0.0155 & 0.9776 & 0.0195 & \\
\hline 93100 & 93200 & 0.2517 & 0.8906 & 0.0234 & \\
\hline 94300 & 94400 & 2.1988 & 0.8859 & 0.0375 & \\
\hline 94900 & 95000 & 0.7608 & 0.2502 & 0.0394 & 0.3012 \\
\hline 97700 & 97800 & 1.8511 & 0.4875 & 0.0791 & 0.5899 \\
\hline 98300 & 98400 & 1.7814 & 0.1391 & 0.0652 & 0.0495 \\
\hline 101400 & 101500 & 0.1407 & 0.0375 & 0.0350 & \\
\hline 102400 & 102500 & 1.6333 & 1.0379 & 0.1378 & 0.0589 \\
\hline 103000 & 103100 & 0.8411 & 0.5397 & 0.0728 & 0.0725 \\
\hline 103700 & 103800 & 0.2707 & 0.7200 & 0.0331 & \\
\hline 105900 & 106000 & 0.1713 & 0.5212 & 0.0348 & \\
\hline 107000 & 107100 & 1.6629 & 0.1758 & 0.1298 & 0.2119 \\
\hline 107800 & 107900 & 0.4762 & 0.0082 & 0.0284 & \\
\hline 108000 & 108100 & 3.6518 & 3.3220 & 0.0818 & 0.8276 \\
\hline 110100 & 110200 & 0.1693 & 0.1533 & 0.0216 & \\
\hline 111500 & 111600 & 9.1210 & 3.7319 & 0.1396 & 0.5290 \\
\hline 112500 & 112600 & 2.8420 & 2.5024 & 0.0400 & \\
\hline 114400 & 114500 & 9.0166 & 7.3517 & 0.1036 & 0.4430 \\
\hline 115400 & 115500 & 1.6372 & 0.9952 & 0.0562 & 0.0452 \\
\hline 116800 & 116900 & 8.0603 & 3.5707 & 0.1278 & 0.3883 \\
\hline 118500 & 118600 & 2.5073 & 0.2503 & 0.0541 & 1.1287 \\
\hline 119400 & 119500 & 6.3333 & 0.3653 & 0.2320 & 0.2325 \\
\hline 120600 & 120700 & 0.2909 & 0.1042 & 0.0268 & \\
\hline 122200 & 122300 & 0.0583 & 0.1801 & 0.0159 & \\
\hline 124700 & 124800 & 0.9050 & 0.0497 & 0.1462 & 0.0709 \\
\hline 125700 & 125800 & 0.4266 & 0.6019 & 0.0270 & \\
\hline 129500 & 129600 & 5.7055 & 0.1196 & 0.1011 & 0.3340 \\
\hline 130600 & 130700 & 0.0594 & 0.1479 & 0.0159 & \\
\hline
\end{tabular}




\subsubsection{Natural Variability}

Field variability around mean concentrations of ${ }^{137} \mathrm{Cs}$ and ${ }^{60} \mathrm{Co}$ within small areas $(30 \mathrm{~m} \times 30 \mathrm{~m}$ ) are presented in Tables 3.16 and 3.17, respectively. The coefficient of variation (CV) exceeds $100 \%$ of the mean in two instances for ${ }^{137} \mathrm{Cs}$ (Sites 12 and 13) and in one instance for ${ }^{60} \mathrm{Co}$ (Site 13 ). The spatial variability at these sites was relatively high with respect to the mean. The CVs for all other sites were less than 100 . This was not unexpected given the relatively low mean concentrations at these permit sites. CVs at areas were there are high concentrations might be higher. The CVs for ${ }^{60} \mathrm{Co}$ are on average less than the CVs for ${ }^{137} \mathrm{Cs}$, suggesting that ${ }^{60} \mathrm{Co}$ is less variable in the surface sediments. This may be an artifact of lower mean concentrations of ${ }^{60} \mathrm{Co}$ than ${ }^{137} \mathrm{Cs}$.

Table 3.16. Summary of cesium-137 concentrations (pCi/g dry weight) for field replicates

\begin{tabular}{cccrr}
\hline Site & N & Mean & $\begin{array}{c}\text { Standard } \\
\text { deviation }\end{array}$ & $\begin{array}{r}\text { Coefficient } \\
\text { of variation }\end{array}$ \\
\hline 1 & 5 & 0.2127 & 0.0496 & 23.34 \\
2 & 3 & 0.1311 & 0.0091 & 6.96 \\
3 & 3 & 0.2155 & 0.1373 & 63.71 \\
4 & 2 & 0.1199 & 0.0479 & 40.01 \\
5 & 3 & 0.0259 & 0.0100 & 38.64 \\
6 & 2 & 0.1788 & 0.0211 & 11.78 \\
7 & 2 & 0.7233 & 0.1181 & 16.34 \\
8 & 3 & 0.8656 & 0.4624 & 53.41 \\
9 & 4 & 0.5639 & 0.4294 & 76.15 \\
10 & 3 & 0.0290 & 0.0061 & 20.89 \\
11 & 2 & 0.0393 & 0.0001 & 0.36 \\
12 & 3 & 0.1773 & 0.2142 & 120.83 \\
13 & 2 & 0.3424 & 0.4232 & 123.61 \\
14 & 3 & 0.2188 & 0.0369 & 16.85 \\
\hline
\end{tabular}


Table 3.17. Summary of ${ }^{\infty} \mathrm{Co}$ concentrations (pCi/g dry weight) for field replicates

\begin{tabular}{cccrr}
\hline Site & N & Mean & $\begin{array}{r}\text { Standard } \\
\text { deviation }\end{array}$ & $\begin{array}{r}\text { Coefficient } \\
\text { of variation }\end{array}$ \\
\hline 1 & 5 & 0.0349 & 0.0035 & 10.18 \\
2 & 3 & 0.0299 & 0.0049 & 16.32 \\
3 & 3 & 0.0283 & 0.0056 & 19.67 \\
4 & 2 & 0.0159 & 0.0094 & 58.90 \\
5 & 3 & 0.0204 & 0.0022 & 10.86 \\
6 & 2 & 0.0254 & 0.0018 & 7.31 \\
7 & 2 & 0.0465 & 0.0162 & 34.93 \\
8 & 3 & 0.0448 & 0.0139 & 31.13 \\
9 & 4 & 0.0229 & 0.0028 & 12.11 \\
10 & 3 & 0.0088 & 0.0011 & 13.01 \\
11 & 2 & 0.0084 & 0.0010 & 12.32 \\
12 & 3 & 0.0137 & 0.0066 & 48.44 \\
13 & 2 & 0.0306 & 0.0321 & 105.04 \\
14 & 3 & 0.0284 & 0.0033 & 11.69 \\
\hline
\end{tabular}

\subsubsection{Laboratory Accuracy}

Results from the interlaboratory split sample analysis are presented in Table 3.18. The only pair of results that is not within $95 \%$ or $99 \%$ confidence limits is the ${ }^{137} \mathrm{Cs}$ concentration for sample $119500 \mathrm{~B}$; all other results between labs are essentially the same. The difference in the one ${ }^{137} \mathrm{Cs}$ result may be attributable to incomplete homogenization in the field before the samples were split, slightly different laboratory methods, and differences in sample dry weights. For instance, the CR-ERP RAL counted these samples for 100 minutes and the state laboratory counted the samples for 120 minutes. Additionally, sample weights were different enough to expect differences in concentration results (Table 3.19).

These results demonstrate that the ESD RAL is generating reproducibly accurate measurements of the concentrations of gamma-emitting radionuclides. 
Table 3.18. Comparison of analysis of split samples analyzed by ESD RAL and TDEC laboratory

\begin{tabular}{|c|c|c|c|c|}
\hline \multirow[b]{2}{*}{ Sample ID } & \multicolumn{2}{|c|}{ ESD RAL } & \multicolumn{2}{|c|}{ TDEC laboratory } \\
\hline & $\begin{array}{l}\text { Concentration } \\
\text { (pCi/g dry wt) }\end{array}$ & $1 \sigma$ error & $\begin{array}{l}\text { Concentration } \\
\text { (pCi/g dry wt) }\end{array}$ & $1 \sigma$ error \\
\hline \multicolumn{5}{|c|}{${ }^{137} \mathrm{Cs}$} \\
\hline 119500B & 6.199 & 0.090 & 7.184 & 0.096 \\
\hline 119600B & 7.709 & 0.110 & 7.462 & 0.093 \\
\hline $120100 \mathrm{~B}$ & 5.377 & 0.070 & 5.389 & 0.075 \\
\hline \multicolumn{5}{|c|}{${ }^{\infty} \mathrm{Co}$} \\
\hline 119500B & 0.210 & 0.022 & 0.254 & 0.033 \\
\hline $119600 \mathrm{~B}$ & 0.258 & 0.033 & 0.247 & 0.031 \\
\hline $120100 \mathrm{~B}$ & 0.234 & 0.017 & 0.196 & 0.030 \\
\hline \multicolumn{5}{|c|}{${ }^{10} \mathrm{~K}$} \\
\hline 119500B & 15.44 & 0.61 & 17.87 & 0.61 \\
\hline 119600B & 16.59 & 0.67 & 16.98 & 0.56 \\
\hline $120100 \mathrm{~B}$ & 8.98 & 0.38 & 9.59 & 0.42 \\
\hline
\end{tabular}

Table 3.19. Comparison of sample dry weights for split samples analyzed by ESD RAL and TDEC laboratory

\begin{tabular}{lcc}
\hline & ESD RAL & \multicolumn{2}{c}{ TDEC laboratory } \\
\cline { 2 - 3 } Sample ID & \multicolumn{2}{c}{ Sample dry weights (g) } \\
\hline 119500B & 392.7 & 323.6 \\
119600B & 341.5 & 281.1 \\
120100B & 559.3 & 390.7 \\
\hline
\end{tabular}

\subsubsection{Laboratory Precision}

DERs for laboratory replicates are presented in Table 3.20 . Concentrations for ${ }^{137} \mathrm{Cs}$ ranged from less than 1 to over 30, spanning almost the entire range of concentrations encountered during this task Of the $62 \mathrm{DERs}$ analyzed for ${ }^{137} \mathrm{Cs}, 14$ were greater than 1; these were all associated with 5 samples analyzed multiple times. Overall instrument precision was good for ${ }^{137} \mathrm{Cs}$ concentrations. In no case did the DERs for ${ }^{60} \mathrm{Co}$ exceed 1 , indicating that the laboratory analyses were consistently precise. 
Table 3.20. DERs for laboratory replicate sample analyses

\begin{tabular}{|c|c|c|c|c|}
\hline Sample ID & $\begin{array}{c}{ }^{137} \mathrm{Cs} \\
\text { Concentration }\end{array}$ & ${ }^{137} \mathrm{Cs}$ DER & $\begin{array}{c}{ }^{60} \mathrm{Co} \\
\text { Concentration }\end{array}$ & ${ }^{60} \mathrm{Co}$ DER \\
\hline 73900 & 0.1344 & 0.2180 & 0.0195 & \\
\hline 74800 & 0.2123 & 0.1871 & 0.0226 & 0.0333 \\
\hline 77100 & 0.1747 & 0.3035 & 0.0155 & 0.0333 \\
\hline 78100 & 0.2745 & 1.0113 & 0.0199 & 0.0333 \\
\hline 79500 & 0.2654 & 0.1500 & 0.0199 & 0.0333 \\
\hline 82400 & 0.2462 & 0.2872 & 0.0354 & 0.0333 \\
\hline 82400 & 0.2462 & 0.1679 & 0.0333 & 0.0333 \\
\hline 83800 & 1.0917 & 1.1496 & 0.0479 & 0.0017 \\
\hline 83800 & 1.0917 & 1.7406 & 0.0631 & 0.2479 \\
\hline 83800 & 1.0917 & 1.3505 & 0.0657 & 0.3105 \\
\hline 83800 & 1.0917 & 0.8660 & 0.1059 & 1.2651 \\
\hline 83800 & 1.0917 & 1.3286 & 0.0823 & 0.6315 \\
\hline 83800 & 1.0917 & 0.5207 & 0.0594 & 0.2274 \\
\hline 83800 & 1.0917 & 1.2144 & 0.0641 & 0.2791 \\
\hline 83800 & 1.0917 & 1.3866 & 0.0932 & 0.7714 \\
\hline 83800 & 1.0917 & 2.1687 & 0.0555 & 0.2077 \\
\hline 83800 & 1.0917 & 1.7062 & 0.0501 & 0.2077 \\
\hline 83800 & 1.0917 & 1.0366 & 0.0633 & 0.3064 \\
\hline 83800 & 1.0917 & 1.1866 & 0.0805 & 0.6040 \\
\hline 86000 & 0.3311 & 0.4301 & 0.0246 & \\
\hline 86800 & 0.1107 & 0.1881 & 0.0071 & 0.6040 \\
\hline 87700 & 0.3316 & 0.0037 & 0.0267 & 0.6040 \\
\hline 89800 & 1.3083 & 13.9704 & 0.0180 & 0.6040 \\
\hline 89800 & 1.3083 & 15.7781 & 0.0174 & 0.6040 \\
\hline 91000 & 0.5328 & 0.4007 & 0.0277 & 0.6040 \\
\hline 92000 & 0.0355 & 0.5312 & 0.0187 & \\
\hline 92500 & 0.1402 & 0.5080 & 0.0198 & 0.0593 \\
\hline 93300 & 0.5099 & 0.2387 & 0.0377 & 0.0593 \\
\hline 94600 & 0.6211 & 0.0278 & 0.0377 & 0.0593 \\
\hline 94900 & 0.7608 & 0.5211 & 0.0419 & 0.0774 \\
\hline 97300 & 23676 & 0.3607 & 0.0593 & 0.5531 \\
\hline 97700 & 1.8511 & 0.2493 & 0.0737 & 0.1001 \\
\hline 98700 & 1.6056 & 0.1083 & 0.0790 & 0.0831 \\
\hline 98900 & 23016 & 0.0360 & 0.0786 & 0.1599 \\
\hline 99200 & 2.2113 & 0.0000 & 0.0558 & 0.1599 \\
\hline 99800 & 13.1168 & 0.2151 & 0.5267 & 0.2243 \\
\hline 100200 & 15.1333 & 0.3999 & 1.2203 & 0.0984 \\
\hline 101000 & 0.1507 & 0.1633 & 0.0388 & \\
\hline 101200 & 0.2595 & 0.1418 & 0.0371 & 0.0941 \\
\hline 102000 & 5.0863 & 0.0918 & 0.0886 & 0.1241 \\
\hline 104100 & 5.0039 & 0.2993 & 0.1840 & 0.2206 \\
\hline 104400 & 0.4426 & 0.1794 & 0.0837 & 0.4701 \\
\hline 105300 & 0.6410 & 0.3241 & 0.0941 & 0.0342 \\
\hline
\end{tabular}




\section{3-21}

Table 3.20 (continued)

\begin{tabular}{ccccc}
\hline Sample ID & $\begin{array}{c}{ }^{137} \text { Cs } \\
\text { Concentration }\end{array}$ & ${ }^{137}$ Cs DER & $\begin{array}{c}{ }^{60} \text { Co } \\
\text { Concentration }\end{array}$ & ${ }^{60}$ Co DER \\
\hline 106300 & 1.7564 & 0.0498 & 0.1613 & 0.1674 \\
107000 & 1.6629 & 0.1550 & 0.1095 & 0.3349 \\
108300 & 31.2622 & 0.3027 & 0.1841 & 0.2147 \\
110100 & 0.1693 & 0.6008 & 0.0244 & 0.2147 \\
112100 & 7.6498 & 0.2489 & 0.1934 & 0.0240 \\
113600 & 0.9113 & 0.2598 & 0.0816 & 0.5859 \\
114900 & 1.9779 & 0.3427 & 0.0649 & 0.1156 \\
115300 & 4.7153 & 0.0956 & 0.2487 & 0.2819 \\
117300 & 3.7023 & 0.1277 & 0.1434 & 0.2016 \\
119700 & 0.6139 & 0.0105 & 0.0456 & 0.0092 \\
121100 & 0.3770 & 0.4190 & 0.0233 & 0.0092 \\
122900 & 1.3998 & 0.8039 & 0.0759 & 0.0092 \\
123400 & 0.0877 & 0.7452 & 0.0262 & \\
124100 & 1.7967 & 0.3085 & 0.2012 & 0.0639 \\
125900 & 1.7100 & 7.5442 & 0.0317 & 0.0639 \\
126200 & 4.0668 & 0.4451 & 0.0982 & 0.6617 \\
129900 & 0.8692 & 0.1772 & 0.0548 & 0.5228 \\
131100 & 0.1995 & 0.0427 & 0.0243 & 0.5228 \\
\hline
\end{tabular}




\section{CONCLUSIONS}

A total of 924 surface sediment grab samples were collected in the Clinch River/Watts Bar Reservoir system and analyzed for ${ }^{137} \mathrm{Cs}$ and ${ }^{60} \mathrm{Co}$ concentrations as part of the near-shore sediment characterization task ${ }^{137} \mathrm{Cs}$ and ${ }^{60} \mathrm{Co}$ concentrations were near or at background concentrations in lower WBR (study Reach 5). However, the frequency of above-background ${ }^{137} \mathrm{Cs}$ concentrations increased nearer to the WOC confluence with the Clinch River. There are several locations in the Clinch River where ${ }^{137} \mathrm{Cs}$ concentrations are above $11.5 \mathrm{pCi} / \mathrm{g}$, which is the minimum concentration that results in an excess risk of cancer of $1 \times 10^{-4}$. These are isolated samples, and all average concentrations for each river mile are well below the $11.5 \mathrm{pCi} / \mathrm{g} .{ }^{60} \mathrm{Co}$ concentrations exceed critical risk thresholds only in the Braden Branch Embayment of Melton Hill Reservoir (study Reach 1), where contamination is not related to DOE activities.

The risk to human health from exposure to ${ }^{137} \mathrm{Cs}$ and ${ }^{60} \mathrm{Co}$ concentrations in surface sediment is dominated by the direct exposure pathway. Concentrations for ${ }^{137} \mathrm{Cs}$ and ${ }^{60} \mathrm{Co}$, averaged by river mile and by study reach, are below levels that would elevate human health risk above $1 \times 10^{-1}$. This observation is true for near-shore sediment (above the winter pool level) in lower Watts Bar Reservoir as well. No sample from lower WBR ever exceeded the $11.5 \mathrm{pCi} / \mathrm{g}$ necessary for this increase in human health risk. The Watts Bar Interagency Permit Group has never rejected a permit for disturbing bottom sediments because of ${ }^{137} \mathrm{Cs}$ and ${ }^{60} \mathrm{Co}$ concentrations exceeding human health risk levels.

The field methods used to identify sediment type were compared to statistical methods of classification using particle size class proportions. The results demonstrated that the field identification was accurate but could be improved if more flexibility between field definition and entry into the data base were allowed.

Evaluation of field methods demonstrated that the homogenization process could have been performed more thoroughly; however, all concentrations were so low that conclusions would not have changed had this occurred. Field variability proved to vary from site to site but in general the variance was less than the mean concentration over areas approximating $30 \mathrm{~m} \mathrm{x30} \mathrm{m.} \mathrm{An} \mathrm{interlaboratory} \mathrm{analysis} \mathrm{comparison} \mathrm{demonstrated} \mathrm{that} \mathrm{the} \mathrm{ESD} \mathrm{RAL} \mathrm{was}$ performing well, with virtually identical results from a state laboratory. The total number of samples in each study reach, and above and below the winter pool elevation, is enough to adequately characterize surface sediment concentrations throughout the CR/WBR system. 


\section{REFERENCES}

DOE. 1994. Remedial Investigation/Feasibility Study Report for Lower Watts Bar Reservoir Operable Unit, DOE/OR/01-1282\&D0, Martin Marietta Energy Systems, Oak Ridge National Laboratory, Oak Ridge, Tennessee.

Morton, R. J. ed. 1962. Status Report No. 3 on Clinch River Study, Clinch River Study Steering Committee, ORNL-3370, Martin Marietta Energy Systems, Oak Ridge National Laboratory, Oak Ridge, Tennessee.

Oakes, T. W., W. F. Ohnesorge, J. S. Eldridge, T. G. Scott, D. W. Parsons, H. M. Hubbard, O. M. Sealand, K E. Shank, and L D. Eyman. 1982. Technical Background Information for the Environmental and Safety Report, Vol 5: The 1977 Clinch River Sediment Survey-Data Presentation, ORNL-5878, Martin Marietta Energy Systems, Oak Ridge National Laboratory, Oak Ridge, Tennessee.

Olsen, C. R., I. L. Larsen, P. D. Lowry, C. R. Moriones, C. J. Ford, K. C. Dearstone, R. R. Turner, B. L. Kimmel, and C. C. Brandt. 1992. Transport and Accumulation of Cesium137 and Mercury in the Clinch River and Watts Bar Reservoir System, ORNL/ER-7, Martin Marietta Energy Systems, Oak Ridge National Laboratory, Oak Ridge, Tennessee.

Struxness, E. G., P. H. Carrigan, Jr., M. A. Churchill, K. E. Cowser, F. J. Morton, D. J. Nelson, and F. L. Parker. 1967. Comprehensive Report of the Clinch River Study, ORNL-4035, Martin Marietta Energy Systems, Oak Ridge National Laboratory, Oak Ridge, Tennessee.

Turner, R. R., C. R. Olsen, and W. J. Wilcox, Jr. 1984. "Environmental Fate of Hg and ${ }^{137} \mathrm{Cs}$ Discharged from Oak Ridge Facilities." In Hemphill, D. D., ed. Trace Substances in Environmental Health-XVII, 1984, A Symposium. Univ. of Missouri, Columbia.

TVA 1986. Instream Contaminant Study-Task 5, Summary Report. Office of Natural Resources and Economic Development. Knoxville, Tennessee. 
APPENDIX A

\section{HUMAN HEALTH RISK CALCULATIONS FOR ${ }^{137} \mathrm{CS}$ AND ${ }^{60} \mathrm{CO}$ USING THE DIRECT EXPOSURE PATHWAY}



The following discussion is based on a handout given to the Watts Bar Interagency Working Group by Owen Hoffman at a 1991 meeting to help decide what concentration of ${ }^{137} \mathrm{Cs}$ and ${ }^{60} \mathrm{Co}$ warranted concern when issuing dredging permits.

Estimating the human health risk from exposure to dredge spoils containing ${ }^{137} \mathrm{Cs}$ or ${ }^{60} \mathrm{Co}$ requires a series of calculations. First we must account for the spreading of a volume of dredged sediment with known concentrations and determine an areal concentration:

$$
A=[X] W D c
$$

$A=$ Area Concentration $\left(\mathrm{pCi} / \mathrm{m}^{2}\right)$

$[\mathrm{X}]=$ Concentration of ${ }^{137} \mathrm{Cs}$ or ${ }^{60} \mathrm{Co}$ in sediment (pCi/g), assumed to be $1 \mathrm{pCi} / \mathrm{g}$ for both ${ }^{137} \mathrm{Cs}$ and ${ }^{60} \mathrm{Co}$

$W=$ Weight of $1 \mathrm{~cm}^{3}$ of sediment $\left(\mathrm{g} / \mathrm{cm}^{3}\right)$, assumed to be $1.43 \mathrm{~g} / \mathrm{cm}^{3}$

$\mathrm{D}=$ Depth of dredge spoils on land, assumed to be $10 \mathrm{~cm}$

c $=$ Conversion factor to convert units from $\mathrm{cm}^{2}$ to $\mathrm{m}^{2}, 10,000$

For these assumptions the value for $A$ is $1.43 \mathrm{E}+05 \mathrm{pCi} / \mathrm{m}^{2}$.

Next, the risk of excess cancer per year for each $\mathrm{pCi} / \mathrm{g}$ is calculated:

$$
\mathrm{R}=\mathrm{Ar}
$$

$\mathrm{R}=$ Risk per year per $\mathrm{pCi} / \mathrm{g}$

$r \quad=$ Risk per year for $1 \mathrm{pCi} / \mathrm{m}^{2}$, for ${ }^{137} \mathrm{Cs}, \mathrm{r}=3.4 \mathrm{E}-11$

$$
\text { for }{ }^{60} \mathrm{Co}, \mathrm{r}=1.3 \mathrm{E}-10
$$

The risk per year for $1 \mathrm{pCi} / \mathrm{g}$ is: $4.86 \mathrm{E}-06$ for ${ }^{137} \mathrm{Cs}$, and

$$
1.85 \mathrm{E}-05 \text { for }{ }^{60} \mathrm{Co} \text {. }
$$

The lifetime risk of excess cancer is calculated by accounting for the length of exposure, the amount of area that is contaminated and the half-life, if applicable:

$$
\begin{aligned}
& \operatorname{LR}\left({ }^{137} \mathrm{Cs}\right)=\mathrm{yR}\left(\mathrm{Cs}^{137}\right)(\mathrm{p}) \mathrm{a} \\
& \operatorname{LR}\left({ }^{60} \mathrm{Co}\right)=\left(\mathrm{yR}\left(\mathrm{Co}^{60}\right)(\mathrm{p}) \mathrm{a}\right) / \mathrm{h}
\end{aligned}
$$

$\mathrm{LR}=$ Lifetime risk, assuming 30 year exposure

$y=$ Years of exposure, assumed to be $30 \mathrm{y}$

$\mathrm{p}=$ Proportion of year that exposure occurs, $(2000 \mathrm{~h}) /(8760 \mathrm{~h} / \mathrm{y})$

a = Correction factor to account for a non-infinite plane of sediment. (Permit applications typically are requesting a small amount of sediment to be disposed of, assume 0.2.)

h $=$ Correction factor to account for 5-year half-life of ${ }^{60} \mathrm{Co}$. (Assume 4, which would mean that the average concentration that one is exposed to over 30 years is $1 / 4$ of the original concentration. This factor does not enter the ${ }^{137} \mathrm{Cs}$ equations because the half-life of ${ }^{137} \mathrm{Cs}$ is 30 years.) 
A-4

As a result, the lifetime excess risk of cancer due to exposure to $1 \mathrm{pCi} / \mathrm{g}$ of ${ }^{137} \mathrm{Cs}$ or ${ }^{60} \mathrm{Co}$ is about the same:

$$
\begin{array}{lll}
\mathrm{LR}\left({ }^{137} \mathrm{Cs}\right) & =30 \mathrm{R}\left({ }^{137} \mathrm{Cs}\right)(2000 / 8760) 0.2 & =6.7 \times 10^{-6} \\
\mathrm{LR}\left({ }^{60} \mathrm{Co}\right) & =\left(30 \mathrm{R}\left({ }^{60} \mathrm{Co}\right)(2000 / 8760) 0.2\right) / 4 & =6.3 \times 10^{-4}
\end{array}
$$

An exposure to $15 \mathrm{pCi} / \mathrm{g}$ of either ${ }^{137} \mathrm{Cs}$ or ${ }^{60} \mathrm{Co}$ would result in a approximately $1 \times 10^{4}$ excess risk of cancer. 


\section{APPENDIX B}

\section{CESIUM-137 AND COBALT-60 CONCENTRATION DATA AND HUMAN HEALTH RISK VALUES, SUMMARIZED BY RIVER MILES}


B-3

Table B.1. ${ }^{15} \mathrm{Cs}$ concentration summarized by river miles

\begin{tabular}{|c|c|c|c|c|c|}
\hline River mile & $\mathbf{N}$ & Mean & $\begin{array}{l}\text { Standard } \\
\text { deviation }\end{array}$ & Minimum & Maximum \\
\hline \multicolumn{6}{|c|}{ Tennessee River } \\
\hline $\begin{array}{l}530 \\
531 \\
533 \\
534 \\
535 \\
538 \\
539\end{array}$ & $\begin{array}{c}13 \\
23 \\
4 \\
2 \\
2 \\
10 \\
4\end{array}$ & $\begin{array}{l}0.72 \\
0.25 \\
0.22 \\
0.34 \\
0.28 \\
0.23 \\
0.19\end{array}$ & $\begin{array}{l}0.93 \\
0.49 \\
0.31 \\
0.42 \\
0.08 \\
0.13 \\
0.11\end{array}$ & $\begin{array}{l}0.02 \\
0.01 \\
0.02 \\
0.04 \\
0.22 \\
0.07 \\
0.06\end{array}$ & $\begin{array}{l}2.71 \\
1.82 \\
0.68 \\
0.64 \\
0.34 \\
0.49 \\
0.29\end{array}$ \\
\hline $\begin{array}{l}541 \\
542 \\
543 \\
544 \\
546 \\
547 \\
548\end{array}$ & $\begin{array}{c}33 \\
9 \\
2 \\
3 \\
7 \\
28 \\
79\end{array}$ & $\begin{array}{l}0.28 \\
0.49 \\
0.54 \\
1.13 \\
0.67 \\
0.43 \\
0.35\end{array}$ & $\begin{array}{l}0.30 \\
0.57 \\
0.10 \\
1.24 \\
1.13 \\
0.46 \\
0.45\end{array}$ & $\begin{array}{l}0.02 \\
0.08 \\
0.47 \\
0.12 \\
0.06 \\
0.01 \\
0.02\end{array}$ & $\begin{array}{l}1.78 \\
1.82 \\
0.62 \\
2.51 \\
3.20 \\
2.20 \\
2.38\end{array}$ \\
\hline $\begin{array}{l}549 \\
550 \\
551 \\
552 \\
554 \\
555 \\
556\end{array}$ & $\begin{array}{c}4 \\
3 \\
11 \\
2 \\
9 \\
3 \\
8\end{array}$ & $\begin{array}{l}1.20 \\
0.76 \\
0.65 \\
1.64 \\
1.01 \\
1.00 \\
1.01\end{array}$ & $\begin{array}{l}1.10 \\
1.04 \\
0.78 \\
1.17 \\
0.87 \\
1.01 \\
1.21\end{array}$ & $\begin{array}{l}0.16 \\
0.13 \\
0.16 \\
0.81 \\
0.30 \\
0.27 \\
0.10\end{array}$ & $\begin{array}{l}2.29 \\
1.97 \\
2.79 \\
2.47 \\
3.11 \\
2.15 \\
3.47\end{array}$ \\
\hline $\begin{array}{l}557 \\
558 \\
559 \\
560 \\
561 \\
562 \\
563\end{array}$ & $\begin{array}{l}36 \\
14 \\
23 \\
11 \\
10 \\
42 \\
6\end{array}$ & $\begin{array}{l}0.42 \\
0.79 \\
0.24 \\
0.72 \\
0.78 \\
0.26 \\
1.03\end{array}$ & $\begin{array}{l}0.47 \\
0.88 \\
0.18 \\
1.08 \\
1.16 \\
0.48 \\
1.47\end{array}$ & $\begin{array}{l}0.04 \\
0.15 \\
0.04 \\
0.07 \\
0.12 \\
0.04 \\
0.05\end{array}$ & $\begin{array}{l}2.07 \\
3.15 \\
0.58 \\
3.02 \\
3.03 \\
2.21 \\
2.94\end{array}$ \\
\hline $\begin{array}{l}564 \\
565 \\
566 \\
567 \\
568 \\
569 \\
570 \\
\end{array}$ & $\begin{array}{c}27 \\
6 \\
13 \\
5 \\
16 \\
8 \\
15 \\
\end{array}$ & $\begin{array}{l}0.56 \\
0.60 \\
0.46 \\
0.61 \\
0.49 \\
0.07 \\
0.19 \\
\end{array}$ & $\begin{array}{l}0.73 \\
0.65 \\
0.27 \\
0.52 \\
0.61 \\
0.06 \\
0.14 \\
\end{array}$ & $\begin{array}{l}0.07 \\
0.10 \\
0.20 \\
0.09 \\
0.09 \\
0.03 \\
0.04\end{array}$ & $\begin{array}{l}2.69 \\
1.88 \\
1.14 \\
1.37 \\
2.12 \\
0.21 \\
0.51 \\
\end{array}$ \\
\hline \multicolumn{6}{|c|}{ Clinch River } \\
\hline $\begin{array}{l}0 \\
1 \\
2 \\
3 \\
4 \\
5 \\
6\end{array}$ & $\begin{array}{l}13 \\
26 \\
16 \\
11 \\
20 \\
2 \\
1\end{array}$ & $\begin{array}{l}2.59 \\
3.24 \\
1.77 \\
1.91 \\
3.41 \\
5.63 \\
1.98\end{array}$ & $\begin{array}{l}2.92 \\
2.63 \\
1.40 \\
1.74 \\
3.19 \\
3.62 \\
3.62\end{array}$ & $\begin{array}{l}0.08 \\
0.30 \\
0.34 \\
0.43 \\
0.23 \\
3.07 \\
1.98\end{array}$ & $\begin{array}{r}10.32 \\
8.61 \\
5.11 \\
5.53 \\
9.49 \\
8.19 \\
1.98\end{array}$ \\
\hline
\end{tabular}


B-4

Table B.1 (continued)

\begin{tabular}{|c|c|c|c|c|c|}
\hline River mile & $\mathbf{N}$ & Mean & $\begin{array}{l}\text { Standard } \\
\text { deviation }\end{array}$ & Minimum & Maximum \\
\hline 7 & 15 & 4.00 & 3.19 & 0.18 & 7.95 \\
\hline 8 & 8 & 1.94 & 1.20 & 0.57 & 4.57 \\
\hline 9 & 12 & 2.18 & 2.06 & 0.35 & 7.63 \\
\hline 10 & 32 & 2.95 & 2.30 & 0.30 & 11.22 \\
\hline 11 & 8 & 4.91 & 6.85 & 1.79 & 21.80 \\
\hline 12 & 5 & 2.64 & 1.86 & 0.87 & 4.83 \\
\hline 13 & 19 & 3.89 & 8.37 & 0.84 & 37.88 \\
\hline 14 & 6 & 3.78 & 2.21 & 1.12 & 6.34 \\
\hline 15 & 7 & 3.30 & 3.53 & 1.39 & 11.13 \\
\hline 16 & 22 & 1.72 & 1.83 & 0.24 & 9.02 \\
\hline 17 & 13 & 1.49 & 0.96 & 0.68 & 4.07 \\
\hline 18 & 28 & 3.87 & 7.20 & 0.26 & 34.13 \\
\hline 19 & 18 & 0.98 & 0.64 & 0.24 & 2.42 \\
\hline 20 & 34 & 2.12 & 5.45 & 0.06 & 31.26 \\
\hline 21 & 16 & 1.33 & 1.43 & 0.10 & 5.00 \\
\hline 22 & 9 & 0.32 & 0.14 & 0.03 & 0.47 \\
\hline 44 & 2 & 0.25 & 0.16 & 0.14 & 0.37 \\
\hline 50 & 20 & 0.52 & 0.53 & 0.05 & 1.95 \\
\hline 101 & 7 & 0.14 & 0.05 & 0.06 & 0.20 \\
\hline \multicolumn{6}{|c|}{ Emory River } \\
\hline 1 & 2 & 0.83 & 0.19 & 0.70 & 0.96 \\
\hline 2 & 11 & 0.92 & 0.91 & 0.06 & 3.33 \\
\hline 3 & 6 & 0.25 & 0.19 & 0.01 & 0.55 \\
\hline 4 & 8 & 0.24 & 0.18 & 0.08 & 0.57 \\
\hline \multicolumn{6}{|c|}{ Piney River } \\
\hline 0 & 3 & 0.18 & 0.21 & 0.02 & 0.42 \\
\hline \multicolumn{6}{|c|}{ Rector Branch } \\
\hline 0 & 3 & 0.23 & 0.21 & 0.07 & 0.47 \\
\hline 1 & 3 & 1.00 & 0.83 & 0.06 & 1.65 \\
\hline \multicolumn{6}{|c|}{ White's Creek } \\
\hline 0 & 7 & 0.77 & 0.55 & 0.10 & 1.74 \\
\hline \multicolumn{6}{|c|}{ King Creek } \\
\hline 0 & 5 & 0.96 & 1.07 & 0.20 & 2.60 \\
\hline 1 & 11 & 0.36 & 0.37 & 0.02 & 0.97 \\
\hline
\end{tabular}


B-5

Table B.1 (continued)

\begin{tabular}{cccccc}
\hline River mile & N & Mean & $\begin{array}{c}\text { Standard } \\
\text { deviation }\end{array}$ & Minimum & Maximum \\
\hline \multicolumn{7}{c}{ Poplar Creek } \\
\hline 1 & 2 & 6.51 & 1.14 & 5.71 & 7.32 \\
4 & 1 & 2.23 & 0.35 & 2.23 & 2.23 \\
& 1 & 0.35 & 4 & 0.35 & 0.35
\end{tabular}


B-6

Table $\mathrm{B} 2{ }^{\mathrm{15}} \mathrm{C}$ s associated risk using the screening method, summarized by river mile

\begin{tabular}{|c|c|c|c|c|c|}
\hline River mile & $\mathbf{N}$ & Mean & $\begin{array}{l}\text { Standard } \\
\text { deviation }\end{array}$ & Minimum & Maximum \\
\hline \multicolumn{6}{|c|}{ Tennessee River } \\
\hline $\begin{array}{l}530 \\
531 \\
533 \\
534 \\
535 \\
538 \\
539\end{array}$ & $\begin{array}{c}13 \\
23 \\
4 \\
2 \\
2 \\
10 \\
4\end{array}$ & $\begin{array}{l}4.83 \mathrm{E}-06 \\
1.65 \mathrm{E}-06 \\
1.45 \mathrm{E}-06 \\
2.29 \mathrm{E}-06 \\
1.87 \mathrm{E}-06 \\
1.56 \mathrm{E}-06 \\
1.29 \mathrm{E}-06\end{array}$ & $\begin{array}{l}6.26 \mathrm{E}-06 \\
3.26 \mathrm{E}-06 \\
2.11 \mathrm{E}-06 \\
2.84 \mathrm{E}-06 \\
5.32 \mathrm{E}-07 \\
8.79 \mathrm{E}-07 \\
7.12 \mathrm{E}-07\end{array}$ & $\begin{array}{l}1.63 \mathrm{E}-07 \\
9.42 \mathrm{E}-08 \\
1.60 \mathrm{E}-07 \\
2.89 \mathrm{E}-07 \\
1.50 \mathrm{E}-06 \\
4.42 \mathrm{E}-07 \\
4.02 \mathrm{E}-07\end{array}$ & $\begin{array}{l}1.82 \mathrm{E}-05 \\
1.22 \mathrm{E}-05 \\
4.59 \mathrm{E}-06 \\
4.30 \mathrm{E}-06 \\
2.25 \mathrm{E}-06 \\
3.30 \mathrm{E}-06 \\
1.95 \mathrm{E}-06\end{array}$ \\
\hline $\begin{array}{l}541 \\
542 \\
543 \\
544 \\
546 \\
547 \\
548\end{array}$ & $\begin{array}{c}33 \\
9 \\
2 \\
3 \\
7 \\
28 \\
79\end{array}$ & $\begin{array}{l}1.85 \mathrm{E}-06 \\
3.28 \mathrm{E}-06 \\
3.65 \mathrm{E}-06 \\
7.56 \mathrm{E}-06 \\
4.51 \mathrm{E}-06 \\
2.91 \mathrm{E}-06 \\
2.33 \mathrm{E}-06\end{array}$ & $\begin{array}{l}2.03 \mathrm{E}-06 \\
3.81 \mathrm{E}-06 \\
6.89 \mathrm{E}-07 \\
8.29 \mathrm{E}-06 \\
7.60 \mathrm{E}-06 \\
3.12 \mathrm{E}-06 \\
2.99 \mathrm{E}-06\end{array}$ & $\begin{array}{l}1.04 \mathrm{E}-07 \\
5.21 \mathrm{E}-07 \\
3.16 \mathrm{E}-06 \\
7.88 \mathrm{E}-07 \\
4.11 \mathrm{E}-07 \\
9.50 \mathrm{E}-08 \\
1.60 \mathrm{E}-07\end{array}$ & $\begin{array}{l}1.19 \mathrm{E}-05 \\
1.22 \mathrm{E}-05 \\
4.14 \mathrm{E}-06 \\
1.68 \mathrm{E}-05 \\
2.15 \mathrm{E}-05 \\
1.47 \mathrm{E}-05 \\
1.59 \mathrm{E}-05\end{array}$ \\
\hline $\begin{array}{l}549 \\
550 \\
551 \\
552 \\
554 \\
555 \\
556\end{array}$ & $\begin{array}{c}4 \\
3 \\
11 \\
2 \\
9 \\
3 \\
8\end{array}$ & $\begin{array}{l}8.06 \mathrm{E}-06 \\
5.10 \mathrm{E}-06 \\
4.33 \mathrm{E}-06 \\
1.10 \mathrm{E}-05 \\
6.76 \mathrm{E}-06 \\
6.73 \mathrm{E}-06 \\
6.74 \mathrm{E}-06\end{array}$ & $\begin{array}{l}7.34 \mathrm{E}-06 \\
6.99 \mathrm{E}-06 \\
5.25 \mathrm{E}-06 \\
7.85 \mathrm{E}-06 \\
5.82 \mathrm{E}-06 \\
6.76 \mathrm{E}-06 \\
8.13 \mathrm{E}-06\end{array}$ & $\begin{array}{l}1.08 \mathrm{E}-06 \\
8.94 \mathrm{E}-07 \\
1.09 \mathrm{E}-06 \\
5.45 \mathrm{E}-06 \\
2.00 \mathrm{E}-06 \\
1.83 \mathrm{E}-06 \\
6.72 \mathrm{E}-07\end{array}$ & $\begin{array}{l}1.53 \mathrm{E}-05 \\
1.32 \mathrm{E}-05 \\
1.87 \mathrm{E}-05 \\
1.65 \mathrm{E}-05 \\
2.08 \mathrm{E}-05 \\
1.44 \mathrm{E}-05 \\
2.33 \mathrm{E}-05\end{array}$ \\
\hline $\begin{array}{l}557 \\
558 \\
559 \\
560 \\
561 \\
562 \\
563\end{array}$ & $\begin{array}{l}36 \\
14 \\
23 \\
11 \\
10 \\
42 \\
6\end{array}$ & $\begin{array}{l}2.80 \mathrm{E}-06 \\
5.29 \mathrm{E}-06 \\
1.60 \mathrm{E}-06 \\
4.81 \mathrm{E}-06 \\
5.25 \mathrm{E}-06 \\
1.73 \mathrm{E}-06 \\
6.89 \mathrm{E}-06\end{array}$ & $\begin{array}{l}3.13 \mathrm{E}-06 \\
5.92 \mathrm{E}-06 \\
1.18 \mathrm{E}-06 \\
7.24 \mathrm{E}-06 \\
7.79 \mathrm{E}-06 \\
3.24 \mathrm{E}-06 \\
9.85 \mathrm{E}-06\end{array}$ & $\begin{array}{l}2.93 \mathrm{E}-07 \\
1.02 \mathrm{E}-06 \\
2.54 \mathrm{E}-07 \\
4.63 \mathrm{E}-07 \\
8.00 \mathrm{E}-07 \\
2.45 \mathrm{E}-07 \\
3.36 \mathrm{E}-07\end{array}$ & $\begin{array}{l}1.39 \mathrm{E}-05 \\
2.11 \mathrm{E}-05 \\
3.88 \mathrm{E}-06 \\
2.02 \mathrm{E}-05 \\
2.03 \mathrm{E}-05 \\
1.48 \mathrm{E}-05 \\
1.97 \mathrm{E}-05\end{array}$ \\
\hline $\begin{array}{l}564 \\
565 \\
566 \\
567 \\
568 \\
569 \\
570\end{array}$ & $\begin{array}{c}27 \\
6 \\
13 \\
5 \\
16 \\
8 \\
15\end{array}$ & $\begin{array}{l}3.76 \mathrm{E}-06 \\
4.05 \mathrm{E}-06 \\
3.09 \mathrm{E}-06 \\
4.12 \mathrm{E}-06 \\
3.26 \mathrm{E}-06 \\
4.56 \mathrm{E}-07 \\
1.30 \mathrm{E}-06\end{array}$ & $\begin{array}{l}4.89 \mathrm{E}-06 \\
4.38 \mathrm{E}-06 \\
1.80 \mathrm{E}-06 \\
3.45 \mathrm{E}-06 \\
4.12 \mathrm{E}-06 \\
3.92 \mathrm{E}-07 \\
9.60 \mathrm{E}-07\end{array}$ & $\begin{array}{l}4.58 \mathrm{E}-07 \\
6.87 \mathrm{E}-07 \\
1.34 \mathrm{E}-06 \\
5.75 \mathrm{E}-07 \\
6.32 \mathrm{E}-07 \\
1.84 \mathrm{E}-07 \\
2.80 \mathrm{E}-07\end{array}$ & $\begin{array}{l}1.80 \mathrm{E}-05 \\
1.26 \mathrm{E}-05 \\
7.66 \mathrm{E}-06 \\
9.16 \mathrm{E}-06 \\
1.42 \mathrm{E}-05 \\
1.38 \mathrm{E}-06 \\
3.43 \mathrm{E}-06\end{array}$ \\
\hline \multicolumn{6}{|c|}{ Clinch River } \\
\hline $\begin{array}{l}0 \\
1 \\
2 \\
3 \\
4 \\
5 \\
6\end{array}$ & $\begin{array}{l}13 \\
26 \\
16 \\
11 \\
20 \\
2 \\
1\end{array}$ & $\begin{array}{l}1.74 \mathrm{E}-05 \\
2.17 \mathrm{E}-05 \\
1.19 \mathrm{E}-05 \\
1.28 \mathrm{E}-05 \\
2.28 \mathrm{E}-05 \\
3.77 \mathrm{E}-05 \\
1.33 \mathrm{E}-05\end{array}$ & $\begin{array}{l}1.95 \mathrm{E}-05 \\
1.76 \mathrm{E}-05 \\
9.38 \mathrm{E}-06 \\
1.17 \mathrm{E}-05 \\
2.14 \mathrm{E}-05 \\
2.42 \mathrm{E}-05 \\
2.42 \mathrm{E}-05\end{array}$ & $\begin{array}{l}5.49 \mathrm{E}-07 \\
2.04 \mathrm{E}-06 \\
2.31 \mathrm{E}-06 \\
2.89 \mathrm{E}-06 \\
1.56 \mathrm{E}-06 \\
2.06 \mathrm{E}-05 \\
1.33 \mathrm{E}-05\end{array}$ & $\begin{array}{l}6.91 \mathrm{E}-05 \\
5.77 \mathrm{E}-05 \\
3.43 \mathrm{E}-05 \\
3.70 \mathrm{E}-05 \\
6.36 \mathrm{E}-05 \\
5.49 \mathrm{E}-05 \\
1.33 \mathrm{E}-05\end{array}$ \\
\hline
\end{tabular}


B-7

Table B.2 (continued)

\begin{tabular}{|c|c|c|c|c|c|}
\hline River mile & $\mathbf{N}$ & Mean & $\begin{array}{l}\text { Standard } \\
\text { deviation }\end{array}$ & Minimum & Maximum \\
\hline 7 & 15 & 2.68E-05 & $2.14 \mathrm{E}-05$ & $1.22 \mathrm{E}-06$ & $5.32 \mathrm{E}-05$ \\
\hline 8 & 8 & $1.30 \mathrm{E}-05$ & $8.04 \mathrm{E}-06$ & $3.85 \mathrm{E}-06$ & $3.06 \mathrm{E}-05$ \\
\hline 9 & 12 & $1.46 \mathrm{E}-05$ & $1.38 \mathrm{E}-05$ & $2.33 E-06$ & $5.12 \mathrm{E}-05$ \\
\hline 10 & 32 & $1.98 \mathrm{E}-05$ & $1.54 \mathrm{E}-05$ & 2.01E-06 & 7.51E-05 \\
\hline 11 & 8 & $3.29 \mathrm{E}-05$ & $4.59 \mathrm{E}-05$ & $1.20 \mathrm{E}-05$ & $1.46 \mathrm{~B}-04$ \\
\hline 12 & 5 & $1.77 \mathrm{E}-05$ & $1.25 \mathrm{E}-05$ & $5.82 \mathrm{E}-06$ & $3.24 \mathrm{E}-05$ \\
\hline 13 & 19 & $260 \mathrm{E}-05$ & 5.61E-05 & $5.64 \mathrm{E}-06$ & $2.54 \mathrm{E}-04$ \\
\hline 14 & 6 & $254 \mathrm{E}-05$ & $1.48 \mathrm{E}-05$ & $7.51 \mathrm{E}-06$ & $4.24 \mathrm{E}-05$ \\
\hline 15 & 7 & 221E-05 & 236E-05 & $9.29 \mathrm{E}-06$ & $7.46 \mathrm{E}-05$ \\
\hline 16 & 22 & $1.15 \mathrm{E}-05$ & $1.22 \mathrm{E}-05$ & $1.60 \mathrm{E}-06$ & $6.04 \mathrm{E}-05$ \\
\hline 17 & 13 & 9.97E-06 & $6.41 \mathrm{E}-06$ & $4.52 \mathrm{E}-06$ & $2.72 E-05$ \\
\hline 18 & 28 & $260 \mathrm{E}-05$ & $4.82 \mathrm{E}-05$ & $1.76 \mathrm{E}-06$ & $229 \mathrm{E}-04$ \\
\hline 19 & 18 & $6.54 \mathrm{E}-06$ & $4.32 \mathrm{E}-06$ & $1.59 \mathrm{E}-06$ & $1.62 \mathrm{E}-05$ \\
\hline 20 & 34 & $1.42 \mathrm{E}-05$ & 3.65E-05 & $3.83 \mathrm{E}-07$ & $2.09 \mathrm{E}-04$ \\
\hline 21 & 16 & 8.89E-06 & 9.57E-06 & $6.87 \mathrm{E}-07$ & $3.35 \mathrm{E}-05$ \\
\hline 22 & 9 & 2.13E-06 & 9.39E-07 & $1.94 \mathrm{E}-07$ & 3.17E-06 \\
\hline 44 & 2 & $1.71 \mathrm{E}-06$ & $1.06 \mathrm{E}-06$ & $9.59 \mathrm{E}-07$ & $2.46 \mathrm{E}-06$ \\
\hline 50 & 20 & $3.51 \mathrm{E}-06$ & $3.58 \mathrm{E}-06$ & $3.30 \mathrm{E}-07$ & 1.31E-05 \\
\hline 101 & 7 & 9.23E-07 & $3.48 \mathrm{E}-07$ & $3.98 \mathrm{E}-07$ & $1.34 \mathrm{E}-06$ \\
\hline \multicolumn{6}{|c|}{ Emory River } \\
\hline 1 & 2 & $5.55 \mathrm{E}-06$ & $1.25 \mathrm{E}-06$ & 4.67E-06 & $6.44 \mathrm{E}-06$ \\
\hline 2 & $\overline{11}$ & $6.17 \mathrm{E}-06$ & 6.07E-06 & $4.02 \mathrm{E}-07$ & 2.23E-05 \\
\hline 3 & 6 & $1.69 \mathrm{E}-06$ & $1.29 \mathrm{E}-06$ & $3.59 \mathrm{E}-08$ & $3.67 \mathrm{E}-06$ \\
\hline 4 & 8 & $1.61 \mathrm{E}-06$ & $1.22 \mathrm{E}-06$ & 5.68E-07 & $3.82 \mathrm{E}-06$ \\
\hline \multicolumn{6}{|c|}{ Piney River } \\
\hline $\mathbf{0}$ & 3 & 1.19E-06 & $1.44 \mathrm{E}-06$ & $1.47 \mathrm{E}-07$ & 2.83E-06 \\
\hline \multicolumn{6}{|c|}{ Rector Branch } \\
\hline 0 & 3 & $1.54 \mathrm{E}-06$ & $1.41 \mathrm{E}-06$ & 4.67E-07 & $3.13 \mathrm{E}-06$ \\
\hline 1 & 3 & $6.68 \mathrm{E}-06$ & $5.58 \mathrm{E}-06$ & 3.93E-07 & $1.10 \mathrm{E}-05$ \\
\hline \multicolumn{6}{|c|}{ White Creek } \\
\hline $\mathbf{0}$ & 7 & $5.19 \mathrm{E}-06$ & $3.71 \mathrm{E}-06$ & $6.56 \mathrm{E}-07$ & 1.17E-05 \\
\hline \multicolumn{6}{|c|}{ King Creek } \\
\hline $\mathbf{0}$ & 5 & $6.43 \mathrm{E}-06$ & 7.14E-06 & $1.32 \mathrm{E}-06$ & $1.74 \mathrm{E}-05$ \\
\hline 1 & 11 & $2.40 \mathrm{E}-06$ & $2.49 \mathrm{E}-06$ & $1.08 \mathrm{E}-07$ & $6.49 \mathrm{E}-06$ \\
\hline \multicolumn{6}{|c|}{ Poplar Creek } \\
\hline $\mathbf{0}$ & 2 & $4.36 \mathrm{E}-05$ & $7.63 \mathrm{E}-06$ & $3.82 \mathrm{E}-05$ & $4.90 \mathrm{E}-05$ \\
\hline 1 & 1 & $1.49 \mathrm{E}-05$ & & $1.49 \mathrm{E}-05$ & $1.49 \mathrm{E}-05$ \\
\hline 4 & 1 & 232E-06 & & 232E-06 & 2.32E-06 \\
\hline
\end{tabular}


B-8

Table B.3. ${ }^{\infty}$ Co concentration summarized by river mile

\begin{tabular}{|c|c|c|c|c|c|}
\hline River mile & $\mathbf{N}$ & Mean & $\begin{array}{l}\text { Standard } \\
\text { deviation }\end{array}$ & Minimum & Maximum \\
\hline \multicolumn{6}{|c|}{ Tennessee River } \\
\hline $\begin{array}{l}530 \\
531 \\
533 \\
534 \\
535 \\
538 \\
539\end{array}$ & $\begin{array}{c}13 \\
23 \\
4 \\
2 \\
2 \\
10 \\
4\end{array}$ & $\begin{array}{l}0.05 \\
0.02 \\
0.02 \\
0.03 \\
0.02 \\
0.02 \\
0.02\end{array}$ & $\begin{array}{l}0.04 \\
0.03 \\
0.01 \\
0.03 \\
0.00 \\
0.01 \\
0.01\end{array}$ & $\begin{array}{l}0.01 \\
0.01 \\
0.02 \\
0.01 \\
0.02 \\
0.01 \\
0.01\end{array}$ & $\begin{array}{l}0.15 \\
0.10 \\
0.03 \\
0.05 \\
0.02 \\
0.03 \\
0.03\end{array}$ \\
\hline $\begin{array}{l}541 \\
542 \\
543 \\
544 \\
546 \\
547 \\
548\end{array}$ & $\begin{array}{c}33 \\
9 \\
2 \\
3 \\
7 \\
28 \\
79\end{array}$ & $\begin{array}{l}0.03 \\
0.03 \\
0.06 \\
0.04 \\
0.05 \\
0.03 \\
0.03\end{array}$ & $\begin{array}{l}0.01 \\
0.02 \\
0.06 \\
0.02 \\
0.06 \\
0.01 \\
0.02\end{array}$ & $\begin{array}{l}0.01 \\
0.02 \\
0.02 \\
0.02 \\
0.02 \\
0.02 \\
0.00\end{array}$ & $\begin{array}{l}0.05 \\
0.07 \\
0.10 \\
0.05 \\
0.17 \\
0.07 \\
0.11\end{array}$ \\
\hline $\begin{array}{l}549 \\
550 \\
551 \\
552 \\
554 \\
555 \\
556\end{array}$ & $\begin{array}{c}4 \\
3 \\
11 \\
2 \\
9 \\
3 \\
8\end{array}$ & $\begin{array}{l}0.05 \\
0.05 \\
0.03 \\
0.08 \\
0.05 \\
0.05 \\
0.07\end{array}$ & $\begin{array}{l}0.03 \\
0.04 \\
0.03 \\
0.05 \\
0.04 \\
0.03 \\
0.08\end{array}$ & $\begin{array}{l}0.02 \\
0.02 \\
0.01 \\
0.05 \\
0.02 \\
0.02 \\
0.02\end{array}$ & $\begin{array}{l}0.09 \\
0.09 \\
0.10 \\
0.11 \\
0.14 \\
0.08 \\
0.25\end{array}$ \\
\hline $\begin{array}{l}557 \\
558 \\
559 \\
560 \\
561 \\
562 \\
563\end{array}$ & $\begin{array}{c}36 \\
14 \\
23 \\
11 \\
10 \\
42 \\
6\end{array}$ & $\begin{array}{l}0.03 \\
0.04 \\
0.03 \\
0.06 \\
0.04 \\
0.03 \\
0.06\end{array}$ & $\begin{array}{l}0.02 \\
0.03 \\
0.01 \\
0.08 \\
0.04 \\
0.02 \\
0.07\end{array}$ & $\begin{array}{l}0.01 \\
0.02 \\
0.01 \\
0.01 \\
0.01 \\
0.01 \\
0.01\end{array}$ & $\begin{array}{l}0.14 \\
0.14 \\
0.05 \\
0.27 \\
0.11 \\
0.13 \\
0.16\end{array}$ \\
\hline $\begin{array}{l}564 \\
565 \\
566 \\
567 \\
568 \\
569 \\
570\end{array}$ & $\begin{array}{c}27 \\
6 \\
13 \\
5 \\
16 \\
8 \\
15\end{array}$ & $\begin{array}{l}0.04 \\
0.05 \\
0.04 \\
0.03 \\
0.03 \\
0.01 \\
0.02\end{array}$ & $\begin{array}{l}0.03 \\
0.04 \\
0.02 \\
0.02 \\
0.03 \\
0.00 \\
0.01\end{array}$ & $\begin{array}{l}0.01 \\
0.01 \\
0.01 \\
0.01 \\
0.02 \\
0.00 \\
0.01\end{array}$ & $\begin{array}{l}0.13 \\
0.12 \\
0.07 \\
0.07 \\
0.10 \\
0.02 \\
0.04\end{array}$ \\
\hline \multicolumn{6}{|c|}{ Clinch River } \\
\hline $\begin{array}{l}0 \\
1 \\
2 \\
3 \\
4 \\
5 \\
6\end{array}$ & $\begin{array}{c}13 \\
26 \\
16 \\
11 \\
20 \\
2 \\
2\end{array}$ & $\begin{array}{l}0.10 \\
0.16 \\
0.10 \\
0.11 \\
0.19 \\
0.30 \\
0.14\end{array}$ & $\begin{array}{l}0.08 \\
0.11 \\
0.05 \\
0.06 \\
0.16 \\
0.13 \\
0.08\end{array}$ & $\begin{array}{l}0.02 \\
0.02 \\
0.02 \\
0.02 \\
0.02 \\
0.21 \\
0.09\end{array}$ & $\begin{array}{l}0.29 \\
0.39 \\
0.24 \\
0.24 \\
0.52 \\
0.39 \\
0.20\end{array}$ \\
\hline
\end{tabular}


B-9

Table B.3 (continued)

\begin{tabular}{|c|c|c|c|c|c|}
\hline River mile & $\mathbf{N}$ & Mean & $\begin{array}{l}\text { Standard } \\
\text { deviation }\end{array}$ & Minimum & Maximum \\
\hline $\begin{array}{c}7 \\
8 \\
9 \\
10 \\
11 \\
12 \\
13\end{array}$ & $\begin{array}{c}15 \\
8 \\
13 \\
32 \\
8 \\
5 \\
19\end{array}$ & $\begin{array}{l}0.17 \\
0.11 \\
0.11 \\
0.10 \\
0.11 \\
0.09 \\
0.09\end{array}$ & $\begin{array}{l}0.10 \\
0.04 \\
0.08 \\
0.06 \\
0.06 \\
0.06 \\
0.04\end{array}$ & $\begin{array}{l}0.03 \\
0.06 \\
0.03 \\
0.02 \\
0.04 \\
0.03 \\
0.04\end{array}$ & $\begin{array}{l}0.34 \\
0.19 \\
0.31 \\
0.25 \\
0.19 \\
0.17 \\
0.20\end{array}$ \\
\hline $\begin{array}{l}14 \\
15 \\
16 \\
17 \\
18 \\
19 \\
20\end{array}$ & $\begin{array}{c}6 \\
7 \\
22 \\
13 \\
28 \\
18 \\
34\end{array}$ & $\begin{array}{l}0.17 \\
0.13 \\
0.07 \\
0.07 \\
0.09 \\
0.06 \\
0.08\end{array}$ & $\begin{array}{l}0.10 \\
0.09 \\
0.03 \\
0.04 \\
0.07 \\
0.05 \\
0.10\end{array}$ & $\begin{array}{l}0.04 \\
0.04 \\
0.02 \\
0.01 \\
0.02 \\
0.02 \\
0.02\end{array}$ & $\begin{array}{l}0.28 \\
0.30 \\
0.14 \\
0.13 \\
0.25 \\
0.21 \\
0.52\end{array}$ \\
\hline $\begin{array}{c}21 \\
22 \\
44 \\
50 \\
101\end{array}$ & $\begin{array}{c}16 \\
9 \\
2 \\
20 \\
7\end{array}$ & $\begin{array}{l}0.08 \\
0.06 \\
0.14 \\
2.74 \\
0.02\end{array}$ & $\begin{array}{l}0.08 \\
0.03 \\
0.15 \\
3.19 \\
0.01\end{array}$ & $\begin{array}{l}0.02 \\
0.03 \\
0.03 \\
0.02 \\
0.01\end{array}$ & $\begin{array}{l}0.26 \\
0.12 \\
0.24 \\
9.06 \\
0.03\end{array}$ \\
\hline \multicolumn{6}{|c|}{ Emory River } \\
\hline $\begin{array}{l}1 \\
2 \\
3 \\
4\end{array}$ & $\begin{array}{c}2 \\
10 \\
6 \\
8\end{array}$ & $\begin{array}{l}0.08 \\
0.05 \\
0.01 \\
0.02\end{array}$ & $\begin{array}{l}0.02 \\
0.04 \\
0.01 \\
0.01\end{array}$ & $\begin{array}{l}0.07 \\
0.01 \\
0.00 \\
0.01\end{array}$ & $\begin{array}{l}0.09 \\
0.15 \\
0.02 \\
0.04\end{array}$ \\
\hline \multicolumn{6}{|c|}{ Piney River } \\
\hline $\mathbf{0}$ & 3 & 0.01 & 0.01 & 0.01 & 0.02 \\
\hline \multicolumn{6}{|c|}{ Rector Branch } \\
\hline $\begin{array}{l}0 \\
1\end{array}$ & $\begin{array}{l}3 \\
3\end{array}$ & $\begin{array}{l}0.03 \\
0.04\end{array}$ & $\begin{array}{l}0.01 \\
0.03\end{array}$ & $\begin{array}{l}0.02 \\
0.01\end{array}$ & $\begin{array}{l}0.03 \\
0.07\end{array}$ \\
\hline \multicolumn{6}{|c|}{ White Creek } \\
\hline 0 & 7 & 0.04 & 0.02 & 0.02 & 0.08 \\
\hline \multicolumn{6}{|c|}{ King Creek } \\
\hline $\begin{array}{l}0 \\
1 \\
\end{array}$ & $\begin{array}{c}5 \\
11 \\
\end{array}$ & $\begin{array}{l}0.05 \\
0.02\end{array}$ & $\begin{array}{l}0.04 \\
0.01\end{array}$ & $\begin{array}{l}0.02 \\
0.01\end{array}$ & $\begin{array}{l}0.11 \\
0.05\end{array}$ \\
\hline \multicolumn{6}{|c|}{ Poplar Creek } \\
\hline $\begin{array}{l}0 \\
1 \\
4\end{array}$ & $\begin{array}{l}2 \\
1 \\
1\end{array}$ & $\begin{array}{l}0.14 \\
0.14 \\
0.01\end{array}$ & $\begin{array}{l}0.06 \\
0.01 \\
0.01\end{array}$ & $\begin{array}{l}0.10 \\
0.14 \\
0.01\end{array}$ & $\begin{array}{l}0.19 \\
0.14 \\
0.01\end{array}$ \\
\hline
\end{tabular}


B-10

Table B.4. ${ }^{\infty} \mathrm{CO}$ associated risk values using the screening method, summarized by river mile

\begin{tabular}{|c|c|c|c|c|c|}
\hline River mile & $\mathbf{N}$ & Mean & $\begin{array}{l}\text { Standard } \\
\text { deviation }\end{array}$ & Minimum & Maximum \\
\hline \multicolumn{6}{|c|}{ Tennessee River } \\
\hline $\begin{array}{l}530 \\
531 \\
533 \\
534 \\
535 \\
538 \\
539\end{array}$ & $\begin{array}{c}13 \\
23 \\
4 \\
2 \\
2 \\
10 \\
4\end{array}$ & $\begin{array}{l}3.13 \mathrm{E}-07 \\
1.38 \mathrm{E}-07 \\
1.26 \mathrm{E}-07 \\
1.91 \mathrm{E}-07 \\
1.30 \mathrm{E}-07 \\
1.52 \mathrm{E}-07 \\
1.20 \mathrm{E}-07\end{array}$ & $\begin{array}{l}2.73 E-07 \\
1.60 \mathrm{E}-07 \\
3.63 \mathrm{E}-08 \\
2.01 \mathrm{E}-07 \\
5.51 \mathrm{E}-09 \\
4.31 \mathrm{E}-08 \\
4.81 \mathrm{E}-08\end{array}$ & $\begin{array}{l}7.08 \mathrm{E}-08 \\
4.80 \mathrm{E}-08 \\
9.66 \mathrm{E}-08 \\
4.92 \mathrm{E}-08 \\
1.26 \mathrm{E}-07 \\
7.18 \mathrm{E}-08 \\
6.76 \mathrm{E}-08\end{array}$ & $\begin{array}{l}9.20 \mathrm{E}-07 \\
6.19 \mathrm{E}-07 \\
1.76 \mathrm{E}-07 \\
3.33 \mathrm{E}-07 \\
1.34 \mathrm{E}-07 \\
2.01 \mathrm{E}-07 \\
1.67 \mathrm{E}-07\end{array}$ \\
\hline $\begin{array}{l}541 \\
542 \\
543 \\
544 \\
546 \\
547 \\
548\end{array}$ & $\begin{array}{c}33 \\
9 \\
2 \\
3 \\
7 \\
28 \\
79\end{array}$ & $\begin{array}{l}1.58 \mathrm{E}-07 \\
2.11 \mathrm{E}-07 \\
4.00 \mathrm{E}-07 \\
2.29 \mathrm{E}-07 \\
3.19 \mathrm{E}-07 \\
1.74 \mathrm{E}-07 \\
1.73 \mathrm{E}-07\end{array}$ & $\begin{array}{l}5.26 \mathrm{E}-08 \\
9.60 \mathrm{E}-08 \\
3.54 \mathrm{E}-07 \\
1.19 \mathrm{E}-07 \\
3.45 \mathrm{E}-07 \\
7.05 \mathrm{E}-08 \\
1.04 \mathrm{E}-07\end{array}$ & $\begin{array}{l}5.11 \mathrm{E}-08 \\
1.46 \mathrm{E}-07 \\
1.50 \mathrm{E}-07 \\
1.02 \mathrm{E}-07 \\
1.16 \mathrm{E}-07 \\
1.08 \mathrm{E}-07 \\
1.50 \mathrm{E}-08\end{array}$ & $\begin{array}{l}3.12 \mathrm{E}-07 \\
4.59 \mathrm{E}-07 \\
6.50 \mathrm{E}-07 \\
3.38 \mathrm{E}-07 \\
1.09 \mathrm{E}-06 \\
4.67 \mathrm{E}-07 \\
7.04 \mathrm{E}-07\end{array}$ \\
\hline $\begin{array}{l}549 \\
550 \\
551 \\
552 \\
554 \\
555 \\
556\end{array}$ & $\begin{array}{c}4 \\
3 \\
11 \\
2 \\
9 \\
3 \\
8\end{array}$ & $\begin{array}{l}3.36 \mathrm{E}-07 \\
2.84 \mathrm{E}-07 \\
2.04 \mathrm{E}-07 \\
5.00 \mathrm{E}-07 \\
3.15 \mathrm{E}-07 \\
2.92 \mathrm{E}-07 \\
4.32 \mathrm{E}-07\end{array}$ & $\begin{array}{l}2.04 \mathrm{E}-07 \\
2.46 \mathrm{E}-07 \\
1.64 \mathrm{E}-07 \\
2.87 \mathrm{E}-07 \\
2.34 \mathrm{E}-07 \\
1.88 \mathrm{E}-07 \\
4.94 \mathrm{E}-07\end{array}$ & $\begin{array}{l}1.35 \mathrm{E}-07 \\
1.37 \mathrm{E}-07 \\
6.40 \mathrm{E}-08 \\
2.97 \mathrm{E}-07 \\
1.25 \mathrm{E}-07 \\
1.16 \mathrm{E}-07 \\
9.83 \mathrm{E}-08\end{array}$ & $\begin{array}{l}5.50 \mathrm{E}-07 \\
5.68 \mathrm{E}-07 \\
6.54 \mathrm{E}-07 \\
7.02 \mathrm{E}-07 \\
8.84 \mathrm{E}-07 \\
4.90 \mathrm{E}-07 \\
1.53 \mathrm{E}-06\end{array}$ \\
\hline $\begin{array}{l}557 \\
558 \\
559 \\
560 \\
561 \\
562 \\
563\end{array}$ & $\begin{array}{l}36 \\
14 \\
23 \\
11 \\
10 \\
42 \\
6\end{array}$ & $\begin{array}{l}1.87 \mathrm{E}-07 \\
2.79 \mathrm{E}-07 \\
1.71 \mathrm{E}-07 \\
4.04 \mathrm{E}-07 \\
243 \mathrm{E}-07 \\
1.57 \mathrm{E}-07 \\
3.97 \mathrm{E}-07\end{array}$ & $\begin{array}{l}1.41 \mathrm{E}-07 \\
2.15 \mathrm{E}-07 \\
7.04 \mathrm{E}-08 \\
5.02 \mathrm{E}-07 \\
2.33 \mathrm{E}-07 \\
1.35 \mathrm{E}-07 \\
4.52 \mathrm{E}-07\end{array}$ & $\begin{array}{l}8.74 \mathrm{E}-08 \\
9.92 \mathrm{E}-08 \\
8.35 \mathrm{E}-08 \\
6.55 \mathrm{E}-08 \\
7.07 \mathrm{E}-08 \\
6.34 \mathrm{E}-08 \\
7.19 \mathrm{E}-08\end{array}$ & $\begin{array}{l}8.51 \mathrm{E}-07 \\
8.77 \mathrm{E}-07 \\
3.24 \mathrm{E}-07 \\
1.70 \mathrm{E}-06 \\
6.73 \mathrm{E}-07 \\
7.86 \mathrm{E}-07 \\
1.03 \mathrm{E}-06\end{array}$ \\
\hline $\begin{array}{l}564 \\
565 \\
566 \\
567 \\
568 \\
569 \\
570\end{array}$ & $\begin{array}{c}27 \\
6 \\
13 \\
5 \\
16 \\
8 \\
15\end{array}$ & $\begin{array}{l}2.33 \mathrm{E}-07 \\
3.28 \mathrm{E}-07 \\
2.21 \mathrm{E}-07 \\
2.18 \mathrm{E}-07 \\
2.16 \mathrm{E}-07 \\
8.33 \mathrm{E}-08 \\
1.23 \mathrm{E}-07\end{array}$ & $\begin{array}{l}2.06 \mathrm{E}-07 \\
2.54 \mathrm{E}-07 \\
1.06 \mathrm{E}-07 \\
1.54 \mathrm{E}-07 \\
1.57 \mathrm{E}-07 \\
2.93 \mathrm{E}-08 \\
5.91 \mathrm{E}-08\end{array}$ & $\begin{array}{l}8.44 \mathrm{E}-08 \\
8.76 \mathrm{E}-08 \\
8.87 \mathrm{E}-08 \\
7.77 \mathrm{E}-08 \\
1.01 \mathrm{E}-07 \\
2.95 \mathrm{E}-08 \\
3.34 \mathrm{E}-08\end{array}$ & $\begin{array}{l}8.44 \mathrm{E}-07 \\
7.53 \mathrm{E}-07 \\
4.29 \mathrm{E}-07 \\
4.66 \mathrm{E}-07 \\
6.17 \mathrm{E}-07 \\
1.22 \mathrm{E}-07 \\
2.35 \mathrm{E}-07\end{array}$ \\
\hline \multicolumn{6}{|c|}{ Clinch River } \\
\hline $\begin{array}{l}0 \\
1 \\
2 \\
3 \\
4 \\
5 \\
6\end{array}$ & $\begin{array}{l}13 \\
26 \\
16 \\
11 \\
20 \\
2 \\
2\end{array}$ & $\begin{array}{l}6.00 \mathrm{E}-07 \\
9.84 \mathrm{E}-07 \\
6.30 \mathrm{E}-07 \\
6.96 \mathrm{E}-07 \\
1.20 \mathrm{E}-06 \\
1.88 \mathrm{E}-06 \\
9.04 \mathrm{E}-07\end{array}$ & $\begin{array}{l}4.97 \mathrm{E}-07 \\
6.78 \mathrm{E}-07 \\
3.13 \mathrm{E}-07 \\
4.00 \mathrm{E}-07 \\
9.79 \mathrm{E}-07 \\
7.84 \mathrm{E}-07 \\
4.69 \mathrm{E}-07\end{array}$ & $\begin{array}{l}1.01 \mathrm{E}-07 \\
1.48 \mathrm{E}-07 \\
1.48 \mathrm{E}-07 \\
1.47 \mathrm{E}-07 \\
1.48 \mathrm{E}-07 \\
1.32 \mathrm{E}-06 \\
5.72 \mathrm{E}-07\end{array}$ & $\begin{array}{l}1.80 \mathrm{E}-06 \\
2.46 \mathrm{E}-06 \\
1.50 \mathrm{E}-06 \\
1.48 \mathrm{E}-06 \\
3.23 \mathrm{E}-06 \\
2.43 \mathrm{E}-06 \\
1.24 \mathrm{E}-06\end{array}$ \\
\hline
\end{tabular}


B-11

Table B. 4 (continued)

\begin{tabular}{|c|c|c|c|c|c|}
\hline River mile & $\mathbf{N}$ & Mean & $\begin{array}{l}\text { Standard } \\
\text { deviation }\end{array}$ & Minimum & Maximum \\
\hline 7 & 15 & $1.06 \mathrm{E}-06$ & $6.45 \mathrm{E}-07$ & $1.72 \mathrm{E}-07$ & 2.14E-06 \\
\hline 8 & 8 & 6.68E-07 & $2.64 \mathrm{E}-07$ & $3.66 \mathrm{E}-07$ & $1.19 \mathrm{E}-06$ \\
\hline 9 & 13 & 6.99E-07 & $5.26 \mathrm{E}-07$ & $1.66 \mathrm{E}-07$ & $1.97 \mathrm{E}-06$ \\
\hline 10 & 32 & $6.27 \mathrm{E}-07$ & $3.52 \mathrm{E}-07$ & $1.37 \mathrm{E}-07$ & $1.56 \mathrm{E}-06$ \\
\hline 11 & 8 & 7.17E-07 & $3.59 \mathrm{E}-07$ & $2.81 \mathrm{E}-07$ & $1.17 \mathrm{E}-06$ \\
\hline 12 & 5 & $5.56 \mathrm{E}-07$ & $3.55 \mathrm{E}-07$ & $1.89 \mathrm{E}-07$ & $1.04 \mathrm{E}-06$ \\
\hline 13 & 19 & $5.88 \mathrm{E}-07$ & 267E-07 & 2.37E-07 & 1.27E-06 \\
\hline 14 & 6 & $1.06 \mathrm{E}-06$ & 6.33E-07 & 2.81E-07 & $1.75 \mathrm{E}-06$ \\
\hline 15 & 7 & 8.35E-07 & $5.79 \mathrm{E}-07$ & $2.23 \mathrm{E}-07$ & $1.88 \mathrm{E}-06$ \\
\hline 16 & 22 & $4.46 \mathrm{E}-07$ & 2.13E-07 & $1.06 \mathrm{E}-07$ & $8.52 \mathrm{E}-07$ \\
\hline 17 & 13 & 4.39E-07 & 230E-07 & 9.13E-08 & 8.32E-07 \\
\hline 18 & 28 & $5.78 \mathrm{E}-07$ & 4.14E-07 & $1.11 \mathrm{E}-07$ & $1.59 \mathrm{E}-0.6$ \\
\hline 19 & 18 & 3.75E-07 & 2.96E-07 & $1.15 \mathrm{E}-07$ & $1.28 \mathrm{E}-06$ \\
\hline 20 & 34 & $5.26 \mathrm{E}-07$ & 6.21E-07 & $1.25 \mathrm{E}-07$ & $3.28 \mathrm{E}-06$ \\
\hline 21 & 16 & $4.81 \mathrm{E}-07$ & $4.69 \mathrm{E}-07$ & 1.13E-07 & $1.60 \mathrm{E}-06$ \\
\hline 22 & 9 & $3.84 \mathrm{E}-07$ & $1.88 \mathrm{E}-07$ & $1.66 \mathrm{E}-07$ & $7.49 \mathrm{E}-07$ \\
\hline 44 & 2 & $8.59 \mathrm{E}-07$ & 9.13E-07 & 213E-07 & $1.50 \mathrm{E}-06$ \\
\hline 50 & 20 & 1.71E-05 & $1.99 \mathrm{E}-05$ & 1.51E-07 & $5.66 \mathrm{E}-05$ \\
\hline 101 & 7 & $1.20 \mathrm{E}-07$ & $5.70 \mathrm{E}-08$ & $3.94 \mathrm{E}-08$ & $1.72 \mathrm{E}-07$ \\
\hline \multicolumn{6}{|c|}{ Emory River } \\
\hline 1 & 2 & 4.84E-07 & $9.74 \mathrm{E}-08$ & 4.15E-07 & $5.53 \mathrm{E}-07$ \\
\hline 2 & 10 & 2.82E-07 & 2.45E-07 & $9.31 \mathrm{E}-08$ & 9.43E-07 \\
\hline 3 & 6 & 7.55E-08 & $5.06 \mathrm{E}-08$ & $8.84 \mathrm{E}-09$ & $1.30 \mathrm{E}-07$ \\
\hline 4 & 8 & $1.36 \mathrm{E}-07$ & 5.43E-08 & $8.59 \mathrm{E}-08$ & $2.26 \mathrm{E}-07$ \\
\hline \multicolumn{6}{|c|}{ Piney River } \\
\hline $\mathbf{0}$ & 3 & $8.56 \mathrm{E}-08$ & 4.15E-08 & 4.18E-08 & $1.24 \mathrm{E}-07$ \\
\hline \multicolumn{6}{|c|}{ Rector Branch } \\
\hline $\mathbf{0}$ & 3 & $1.70 \mathrm{E}-07$ & $5.02 \mathrm{E}-08$ & 1.15E-07 & 2.13E-07 \\
\hline 1 & 3 & $2.49 \mathrm{E}-07$ & $1.70 \mathrm{E}-07$ & $6.94 \mathrm{E}-08$ & 4.07E-07 \\
\hline \multicolumn{6}{|c|}{ White Creek } \\
\hline 0 & 7 & 2.26E-07 & $1.43 \mathrm{E}-07$ & $1.20 \mathrm{E}-07$ & $5.22 \mathrm{E}-07$ \\
\hline \multicolumn{6}{|c|}{ King Creek } \\
\hline 0 & 5 & 3.09E-07 & 2.39E-07 & $1.44 \mathrm{E}-07$ & 7.02E-07 \\
\hline 1 & 11 & 1.53E-07 & $6.28 \mathrm{E}-08$ & $5.76 \mathrm{E}-08$ & 2.90E-07 \\
\hline \multicolumn{6}{|c|}{ Poplar Creek } \\
\hline $\mathbf{0}$ & 2 & 9.03E-07 & $3.83 \mathrm{E}-07$ & 6.32E-07 & $1.17 \mathrm{E}-06$ \\
\hline 1 & 1 & 8.45E-07 & & 8.45E-07 & 8.45E-07 \\
\hline 4 & 1 & $7.96 \mathrm{E}-08$ & & $7.96 \mathrm{E}-08$ & 7.96E-08 \\
\hline
\end{tabular}




\section{APPENDIX C}

SUMMARY OF BRADEN BRANCH DATA 



\section{PURPOSE}

Braden Branch is a suspected source of cobalt-60 contamination to Melton Hill Reservoir. Because of this, several sampling efforts have attempted to characterize the cobalt -60 contamination of sediment in the immediate vicinity of Braden Branch and slightly downstream. The purpose of this report is to summarize the data from these sampling efforts and assess the risk to human health associated with exposure to the contaminated areas.

\section{STUDY AREA}

Braden Branch Creek is a small stream that enters Melton Hill Reservoir at approximately CRM 50.5. This is several hundred meters upstream and on the opposite shoreline from the Oak Ridge Marina (Plate 1). The creek is dammed by a railroad berm that separates it from Melton Hill Reservoir. All surface water exchange between the two water bodies is via a culvert that passes through the railroad berm. The damming caused by this berm creates an embayment on the upstream side. This embayment acts as a settling pond for particulates washed from the Braden Branch watershed.

\section{HISTORICAL BACKGROUND}

In 1968, personnel associated with ORNL noted abnormally high radioactivity in a water sample from the Braden Branch area of the Clinch River. The source of this radioactivity was traced to the ANC located on Braden Branch Creek. ANC produced cobalt-60 as a radiation source for medical instruments between 1962 to 1970 under the jurisdiction of the U.S. Atomic Energy Commission (until 1965) and the State of Tennessee (until closing).

After the contamination was detected in the Clinch River, radiation surveys on- and offsite revealed exposure rates in the $\mathrm{mR} / \mathrm{hr}$ to $\mathrm{R} / \mathrm{hr}$ range. The ANC facility was closed in 1970 and clean-up efforts commenced. The clean-up was restricted to the immediate area around the plant. No effort was made to clean up contamination in the Braden Branch embayment or areas downstream. The Division of Radiological Health of the TDEC obtains monthly radiation surveys in the area (approximately 50 acres) and thorough annual measurements near the building site. Public access to the ANC building and surrounding land is restricted.

In a paper presented at the 1987 Oak Ridge Model Conference by researchers at the University of Tennessee, TDHE, and TVA, 1987 dose rates were reported at $1 \mathrm{mR} / \mathrm{yr}$ at the building site and $0.1 \mathrm{mR} / \mathrm{yr}$ in the embayment. 1987 sediment concentrations of cobalt-60 in the Braden Branch embayment were reported to be as high as $152.0 \mathrm{pCi} / \mathrm{g}$ in the top 6 inches of sediment and up to $383.0 \mathrm{pCi} / \mathrm{g}$ in the 6-12 inch interval.

\section{RECENT DATA}

Sediment sampling was conducted in the immediate vicinity of Braden Branch as part of the ongoing Clinch River Remedial Investigation. A total of 20 sediment grab samples were taken between July 25 and August 10, 1990. These samples were taken with a Ponar grab sampler and were intended to characterize the radionuclide concentrations in the surface sediment only. A single sediment core was also taken within 300 meters of the confluence of Braden Branch and Melton Hill Reservoir. This core was divided into separate samples by depth intervals $(2 \mathrm{~cm}$ to $48 \mathrm{~cm}$ ) and analyzed to provide a vertical profile of sediment 
contamination. Sample locations for grab samples (ID \#109-125, and 188-190) and for the core sample (ID\# 187) are shown on Plate 1.

Data from two additional cores may provide information on historic downstream transport of cobalt-60 contamination. One core was taken at CRM 44, upstream of the Solway Bridge. A second core was taken at CRM 23.9, slightly upstream from Melton Hill Dam.

\section{REFERENCE CONCENTRATIONS}

Radionuclides are present throughout the world due to natural occurrence and from man-made sources. Sediment samples taken from Norris Reservoir provide reference or "background" concentrations for radionuclides and other contaminants being examined in the Clinch River Remedial Investigation. Norris Reservoir background levels of cobalt-60 are below minimum detectable activity and range from $0-0.3 \mathrm{pCi} / \mathrm{g}$. These concentrations originated from atmospheric testing of nuclear weapons and not from DOE facilities in Oak Ridge.

\section{DATA SUMMARY}

Table 1 summarizes the 1990 cobalt- 60 surface sediment concentrations from the 20 grab samples and the top 2 centimeters of the core sample.

Table C.1. Summary statistics for cobalt-60 concentrations in Braden Branch sediments (Concentrations are reported in $\mathrm{pCi} / \mathrm{g}$.)

\begin{tabular}{ccccc}
\hline Number of observations & Minimum & Maximum & Mean & Median \\
\hline 21 & 0.02 & 9.05 & 2.90 & 1.26 \\
\hline
\end{tabular}

Plate 2 shows the cobalt -60 concentration at each of the sample locations. Locations with the highest concentrations (>1.01 pCi/g) are, with the exception of sample \#190 (cobalt-60 concentration $=4.53 \mathrm{pCi} / \mathrm{g}$ ), within 200 meters of the culvert under the railroad bridge where Braden Branch enters Melton Hill Reservoir.

Figure 1 shows cobalt-60 concentration with depth in core \#18700G and compares these concentrations with those from the core taken upstream from Melton Hill Dam (core \#8200G). The profile for the core at CRM 44 is similar to the Melton Hill Dam core. The profile for the Braden Branch core indicates that there are two concentration peaks. The first is at a depth of $22 \mathrm{~cm}$ with a concentration of $20.07 \mathrm{pCi} / \mathrm{g}$. The second peak is at $33 \mathrm{~cm}$ with an associated concentration of $39.33 \mathrm{pCi} / \mathrm{g}$. The concentrations from the two downstream cores are all less than $1.00 \mathrm{pCi} / \mathrm{g}$. Most of the concentrations in these cores are below the detectable limit. Notice that the concentrations of cobalt-60 in the Braden Branch core do not approach detectable levels $(0-0.3 \mathrm{pCi} / \mathrm{g})$ until a depth of $45 \mathrm{~cm}$.

\section{SUMMARY AND INTERPRETATION}

Cobalt -60 concentrations in surface sediment within the Braden Branch embayment were as high as $1287.0 \mathrm{pCi} / \mathrm{g}$ in 1977 . The highest concentration found in surface sediment in the 
embayment during a 1987 survey was $152.0 \mathrm{pCi} / \mathrm{g}$. There are several explanations for this drop in concentration. First, the half-life of cobalt-60 is five years, which means just from natural decay the $1287 \mathrm{pCi} / \mathrm{g}$ in 1977 would have been reduced to $322 \mathrm{pCi} / \mathrm{g}$ by 1987 . Second, redistribution and dilution of contaminated sediment could be responsible for spreading and mixing contaminated sediment within the embayment and into Melton Hill Reservoir. The fact that the highest cobalt-60 concentrations in 1977 were in the upper end of the embayment but in 1987 were in the lower end suggests that there is some movement of contaminants. Finally, along with redistribution, contaminated sediments may be buried by "cleaner" sediments. There is some historic evidence of this as well. In the 1987 survey of the embayment, a cobalt -60 concentration in the top 6 inches of one site was $39.9 \mathrm{pCi} / \mathrm{g}$ while the concentration in the 6 inches below this was $383.0 \mathrm{pCi} / \mathrm{g}$. However, this pattern is by no means consistent throughout the embayment.

The cobalt- 60 sediment concentrations in the Melton Hill Reservoir in the immediate vicinity of the Braden Branch culvert are at least an order of magnitude above background levels. The highest concentrations are almost entirely within 200 meters of the culvert under the railroad bridge where Braden Branch flows into Melton Hill Reservoir. The concentration at the sample 190 location suggests that contaminant transport has occurred in a southeasterly direction within the small channel. Low concentrations at all of the channel outlets suggest that downstream transport of cobalt-60 into the main channel of Melton Hill Reservoir may have been minimal in the recent past.

The cobalt -60 concentration profile from the sediment core indicates that there are several large peaks in cobalt-60 concentrations that are 2 orders of magnitude above background levels. While concentrations in the two downstream cores may suggest that downstream movement of contamination has been minimal, the results are inconclusive. The near-background concentrations in these cores could be a result of contaminant dilution or simply because the cores were not taken where contaminants had deposited.

These results and the results from previous studies indicate that Braden Branch has been a source of cobalt-60 contamination to Melton Hill Reservoir. Furthermore, the elevated concentrations in the surface sediments suggests that Braden Branch may still be contributing lesser amounts of cobalt- 60 to the reservoir.

\section{HUMAN HEALTH RISK}

It is extremely difficult to quantitatively access human health risk from exposure to contaminants in the environment because the data necessary to determine exposure and doses are difficult to obtain. These data includes how fast and how efficiently contamination is transported along various exposure routes, the magnitude and duration of the exposure, and the relationship between exposure and health risk. Because of these problems, a set of assumptions is typically used to provide conservative screening estimates of lifetime risk of cancer incidence. The Environmental Protection Agency has developed a list of conversion factors based on these assumptions and provides guidance in their use to allow the conversion of contaminant concentrations in the environment into estimates of human health risk resulting from various exposure routes (EPA 1991a and b).

There is virtually no risk from cobalt-60 in deep undisturbed sediment. Exchange with the water column is minimal, and water acts as an effective shield to gamma radiation. If the sediment is exposed due to draw-down of the water, the potential risk is similar to cobalt- 60 
in surface soil. The exposure is then dominated by the size of the area containing cobalt-60, the length of time an individual resides in the area of contamination, and the occurrence of features that act to partially or completely shield an individual from the gamma radiation.

To provide a screening-level human health risk estimate due to exposure to sediments in the Braden Branch area, the following assumptions were made (1) the excess risk of cancer resulting from direct (unshielded) exposure to sediments with a cobalt- 60 concentration of $1 \mathrm{pCi} / \mathrm{g}$ for $2000 \mathrm{hr} / \mathrm{yr}$ for thirty years is $5.58 \times 10^{-4}$ (EPA 1991a), (2) the observed concentrations are evenly distributed to a depth of $10 \mathrm{~cm}$, and (3) a modifying factor of 0.2 is used to account for an area that is more narrow than an infinite plane. In addition, the effective exposure period will be equivalent to 7 years, given the 5-year half-life of cobalt-60 and an actual exposure period equal to 30 years. Given these assumptions, the estimated excess risk of cancer from being exposed to sediment with a cobalt- 60 concentration of $1 \mathrm{pCi} / \mathrm{g}$ is approximately $3 \times 10^{-5}$.

Table 2 presents observed cobalt-60 sediment concentrations and the associated screening-level risk estimates at locations in Braden Branch embayment (upstream of the culvert) and in Melton Hill Reservoir (downstream of the culvert). The screening-level excess lifetime risk of cancer as a result of being exposed to sediment from the embayment is above $6 \times 10^{-4}$ in all cases. The 1992 estimated concentrations were determined by dividing the 1987 concentrations by two (the half-life of cobalt-60 is 5 years). Exposure to sediments immediately downstream from the culvert poses a lesser risk.

Table 2. Estimates of risk of excess lifetime incidence of cancer resulting from exposure to sediment in and near the Braden Branch embayment

\begin{tabular}{lccc}
\hline Location of sample & Date & $\begin{array}{c}\text { Screening-level } \\
\text { estimate of } \\
\text { ( } \mathrm{pCi} / \mathrm{C})\end{array}$ & Excess risk of cancer \\
\hline $25 \mathrm{ft}$ upstream of culvert & 1977 & 1101.0 & $\leq 8 \times 10^{-3}$ \\
$25 \mathrm{ft}$ downstream of culvert & 1977 & 300.8 & $\leq 2 \times 10^{-3}$ \\
$160 \mathrm{ft}$ upstream from culvert & 1987 & 383.0 & $\leq 3 \times 10^{-3}$ \\
$160 \mathrm{ft}$ upstream from culvert & 1992 & $191.5^{\circ}$ & $\leq 1 \times 10^{-3}$ \\
$240 \mathrm{ft}$ upstream from culvert & 1987 & 152.0 & $\leq 1 \times 10^{-3}$ \\
$240 \mathrm{ft}$ upstream from culvert & 1992 & $76.0^{\circ}$ & $\leq 6 \times 10^{-3}$ \\
$25 \mathrm{ft}$ downstream from culvert & 1990 & 9.05 & $\leq 7 \times 10^{-3}$ \\
\hline
\end{tabular}

"Estimate; assumes a half-life of 5 years for cobalt- 60 .

The average concentration observed in surface sediment for all 1990 samples was $2.90 \mathrm{pCi} / \mathrm{g}$, which translates to an excess risk of $\leq 2 \times 10^{-5}$. However, for samples in the immediate vicinity of the railroad bridge, the average concentration of cobalt- 60 was $5.73 \mathrm{pCi} / \mathrm{g}$, which translates to an excess risk of cancer of $\leq 4 \times 10^{-5}$. The maximum cobalt- 60 concentration in the sediment core was almost $40 \mathrm{pCi} / \mathrm{g}$, which translates to an excess risk of cancer of $\leq 3 \times 10^{-4}$, assuming this sediment was brought to the surface. 
C-7

It should be noted that the sediments in the Braden Branch area are exposed for some part of the year but probably not enough to allow for a $2000 \mathrm{hr} / \mathrm{yr}$ exposure. Therefore, our calculations are conservative and probably are relevant only to the case where sediments are dredged and used as a source of top soil.

\section{REFERENCES}

Miller, L F., E. S. Stetar, J. H. Coleman, A Payne, J. Hoffelt, and D. J. Auslander. 1987. "Monitoring of Radionuclide Migration and Exposure Rates From the American Nuclear Corporation Plant Site." In: Proceedings of the 1987 Oak Ridge Model Conference, Volume III, Health and Safety. CONF-871075-Vol. 3.

Environmental Protection Agency, 1991a. Health Effects Assessment Summary Tables. Annual FY-1991. OERR 9200.6-303 (91-1).

Environmental Protection Agency, 1991b. OSWER Directive 9285.6-303. March 25, 1991. 


\section{DISTRIBUTION}

1. Y. S. Bao

2. L. W. Barnthouse

*3. L. D. Bates

4. T. C. Bennett

*5. B. A Berven

6. M. S. Bevelhimer

7. L. R. Bond

8. H. L. Boston

9. C. C. Brandt

10. A. L Brenkert

11. R. B. Cook

*12. J. H. Cushman

13. T. L. Dahl

14. V. H. Dale

15. E. L. Etnier

16. C. J. Ford

17. D. E. Fowler

18. M. L. Frank

19. A M. Gonzales

20. R. L Graham

21. M. S. Greeley

22. P. J. Halsey

23. W. W. Hargrove

24. S. G. Hildebrand

25. S. K Holladay

*26. P. Kanciruk

27. B. L. Kimmel
28. T. M. Koepp

29. L. A. Kszos

30. D. A. Levine

31. J. M. Loar

32. P. L Lund

33-35. D. M. Matteo

36. C. W. McGinn

37. P. D. Miller

38-39. P. T. Owen

40. T. L. Phipps

*41. D. E. Reichle

42. K A Rose

43. E. R. Sain

*44. M. E. Sale

45. D. D. Schmoyer

46. R. L. Schmoyer

47. C. M. Self

*48. F. E. Sharples

*49. S. H. Stow

50. G. W. Suter

51. Central ER Doc. Mgmt. Center

52. ORNL ER Doc. Mgmt. Center

53-54. Clinch River Doc. Mgmt. Center-RC

55. Central Research Library

56. ORNL Patent Section

57. Laboratory Records Department

58-60. ESD Library

*Executive Summary only

61. B. G. Blaylock, SENES Corporation, 677 Emory Valley Road, Suite C, Oak Ridge, TN 37830

62. S. Brooks, Jacobs Engineering, 125 Broadway, Oak Ridge, TN 37830

63. T. E. Mattis, Jacobs Engineering, 125 Broadway, Oak Ridge, TN 37830

64. J. S. Hammonds, SENES, 677 Emory Valley Road, Suite C, Oak Ridge, TN 37830

65. F. O. Hoffman, SENES, 677 Emory Valley Road, Suite C, Oak Ridge, TN 37830

66. R. N. Farvolden, Professor, Department of Earth Sciences, University of Waterloo, Waterloo, Ontario N2L 3G1, Canada

67. D. W. Freckman, Director, College of Natural Resources, 101 Natural Resources Building, Colorado State University, Fort Collins, CO 80523

68. G. S. Saylor, Professor, 10515 Research Drive, Suite 100, The University of Tennessee, Knoxville, TN 37932-2567

69. D. M. Carden, DOE Oak Ridge Operations Office, P.O. Box 2001, Oak Ridge, TN 378318541

70. M. S. Ferre, DOE Oak Ridge Operations Office, P.O. Box 2001, Oak Ridge, TN 37831

71. C. Gist, DOE Oak Ridge Operations Office, P.O. Box 2001, Oak Ridge, TN 37831 
72. Office of Assistant Manager for Energy Research and Development, DOE Oak Ridge Operations Office, P.O. Box 2001, Oak Ridge, TN 37831-8600

73. G. Y. Jordy, Director, Office of Program Analysis, Office of Energy Research, ER-30, G-226, U.S. Department of Energy, Washington, DC 20545

74. A. Patrinos, Director, Environmental Sciences Division, Office of Health and Environmental Research, ER-74, U.S. Department of Energy, Washington, DC 20585

75. F. J. Wobber, Environmental Sciences Division, Office of Health and Environmental Research, ER-74, U.S. Department of Energy, Washington, DC 20585

76-77. Office of Scientific and Technical Information, P.O. Box 62, Oak Ridge, TN 37831 


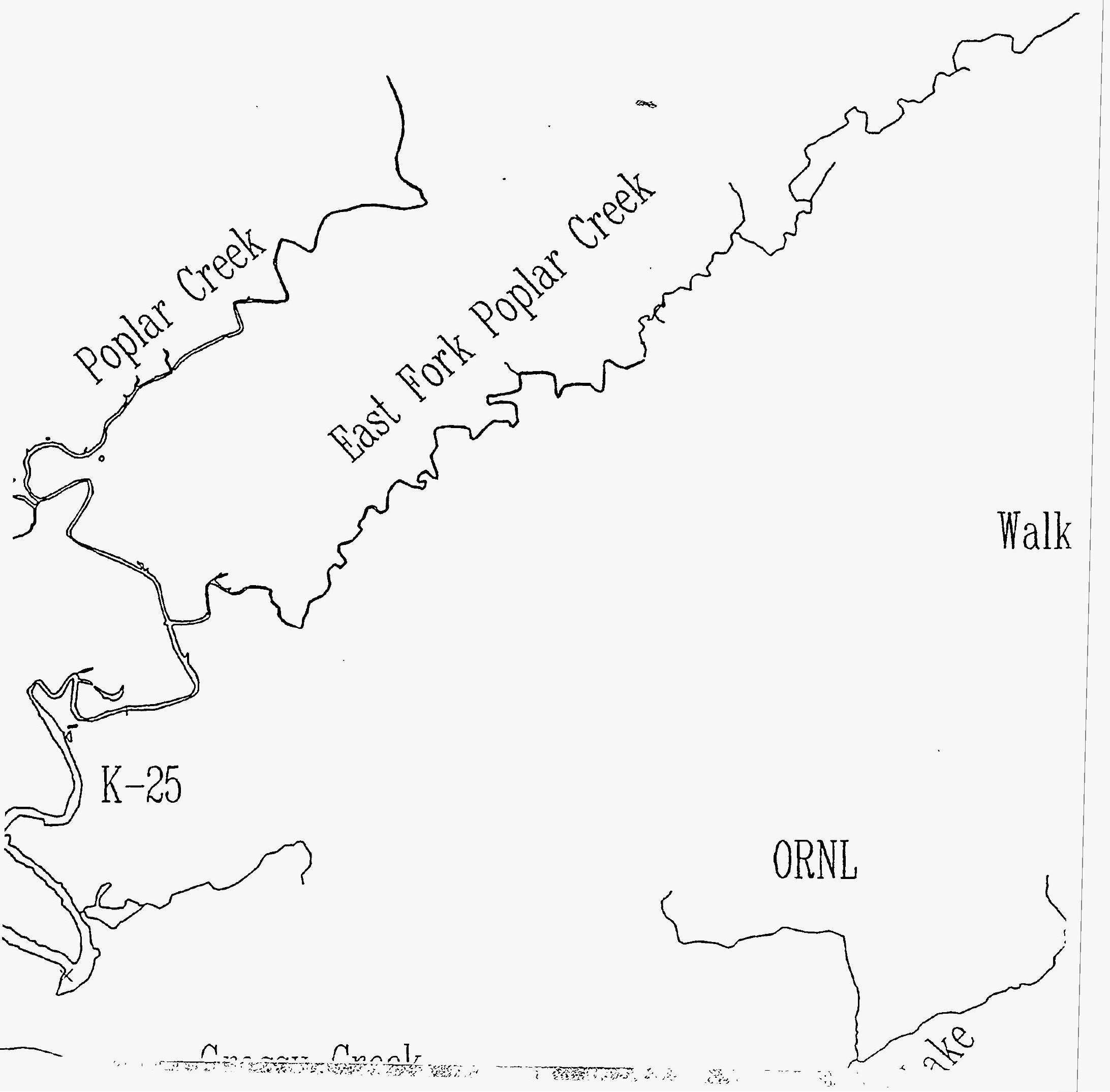




\section{PLATE 2}

Sample locations and Cesium-137 concentrations surface sediments in Clinch River arm of Watts Bar Reservoir

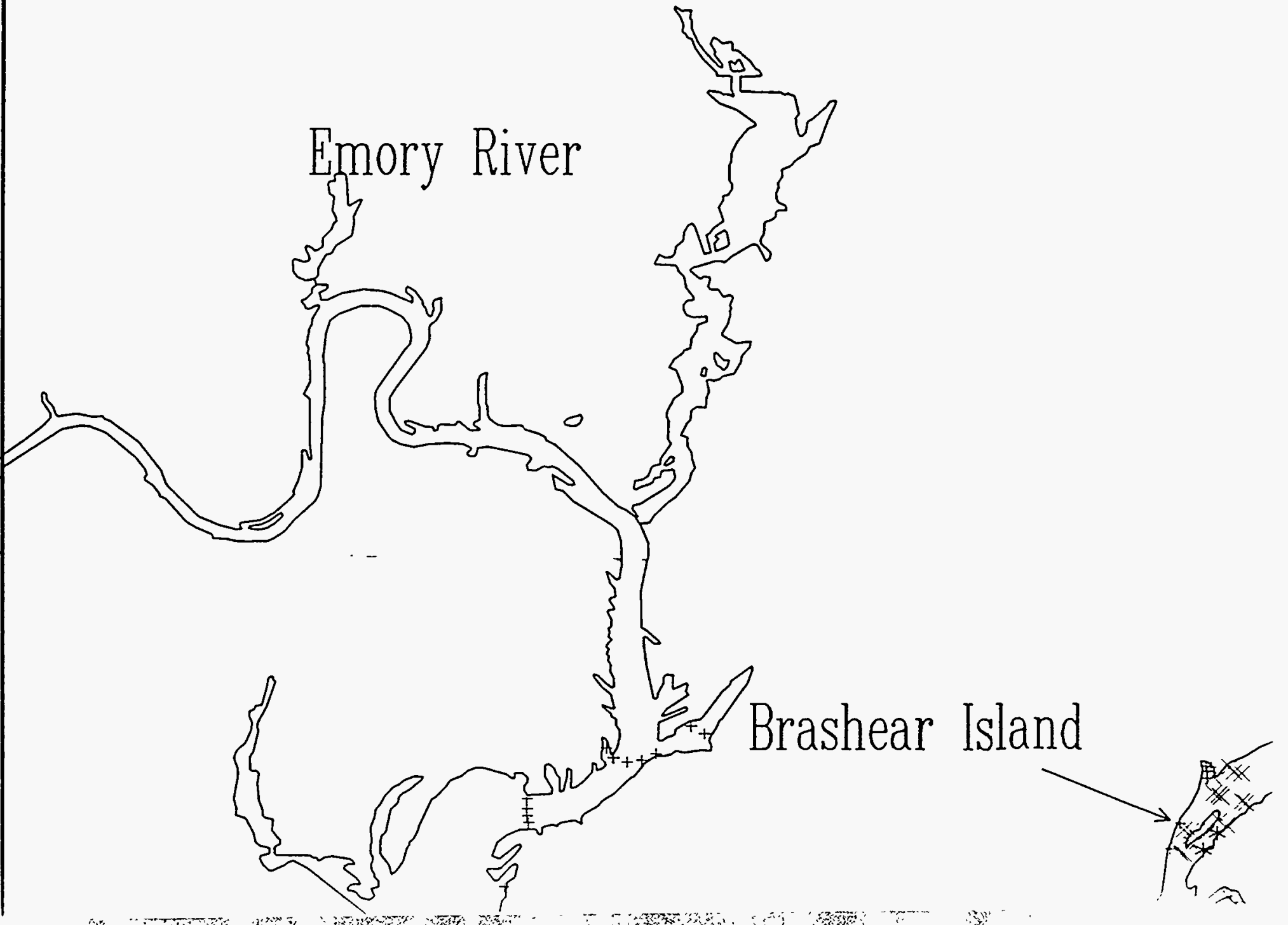




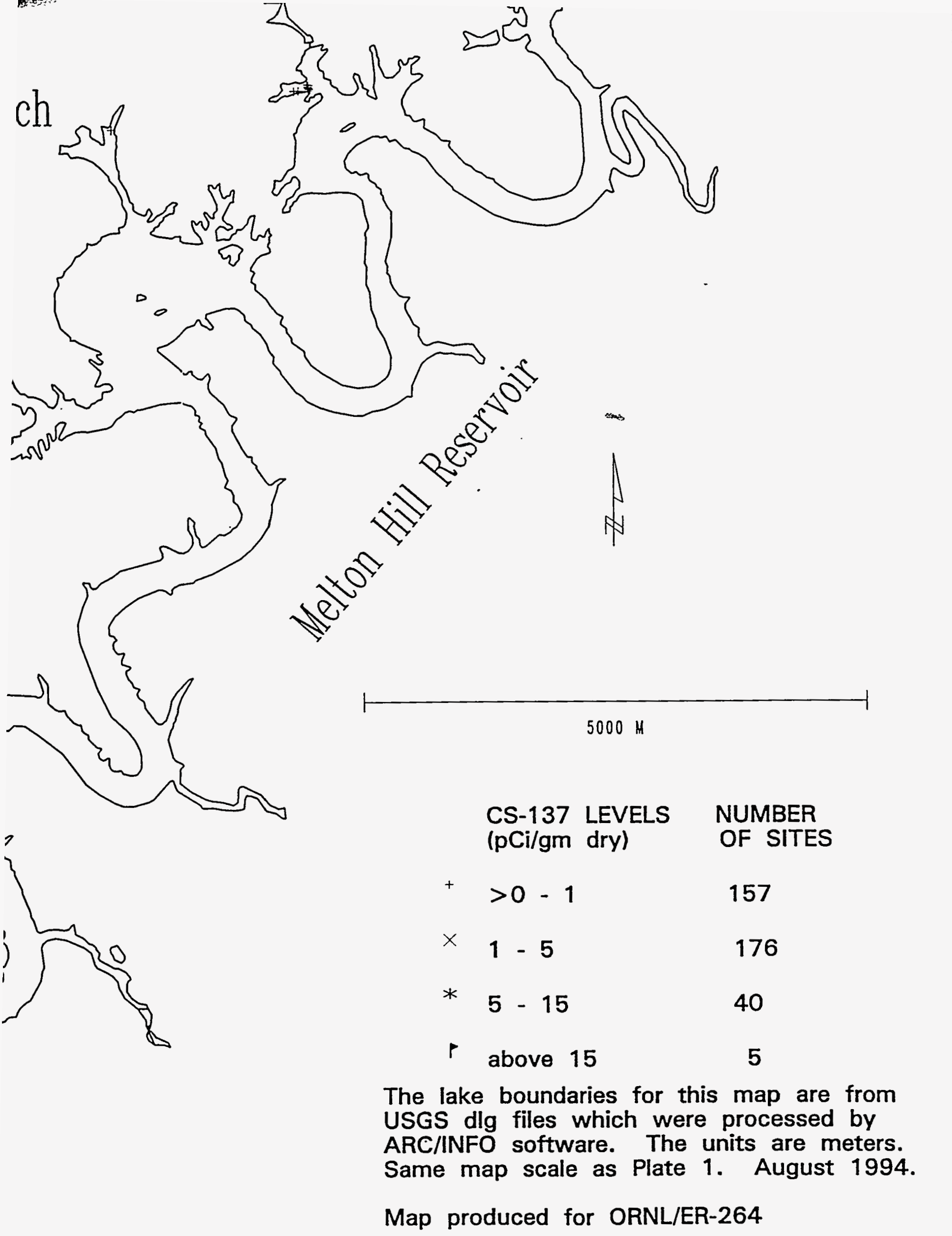




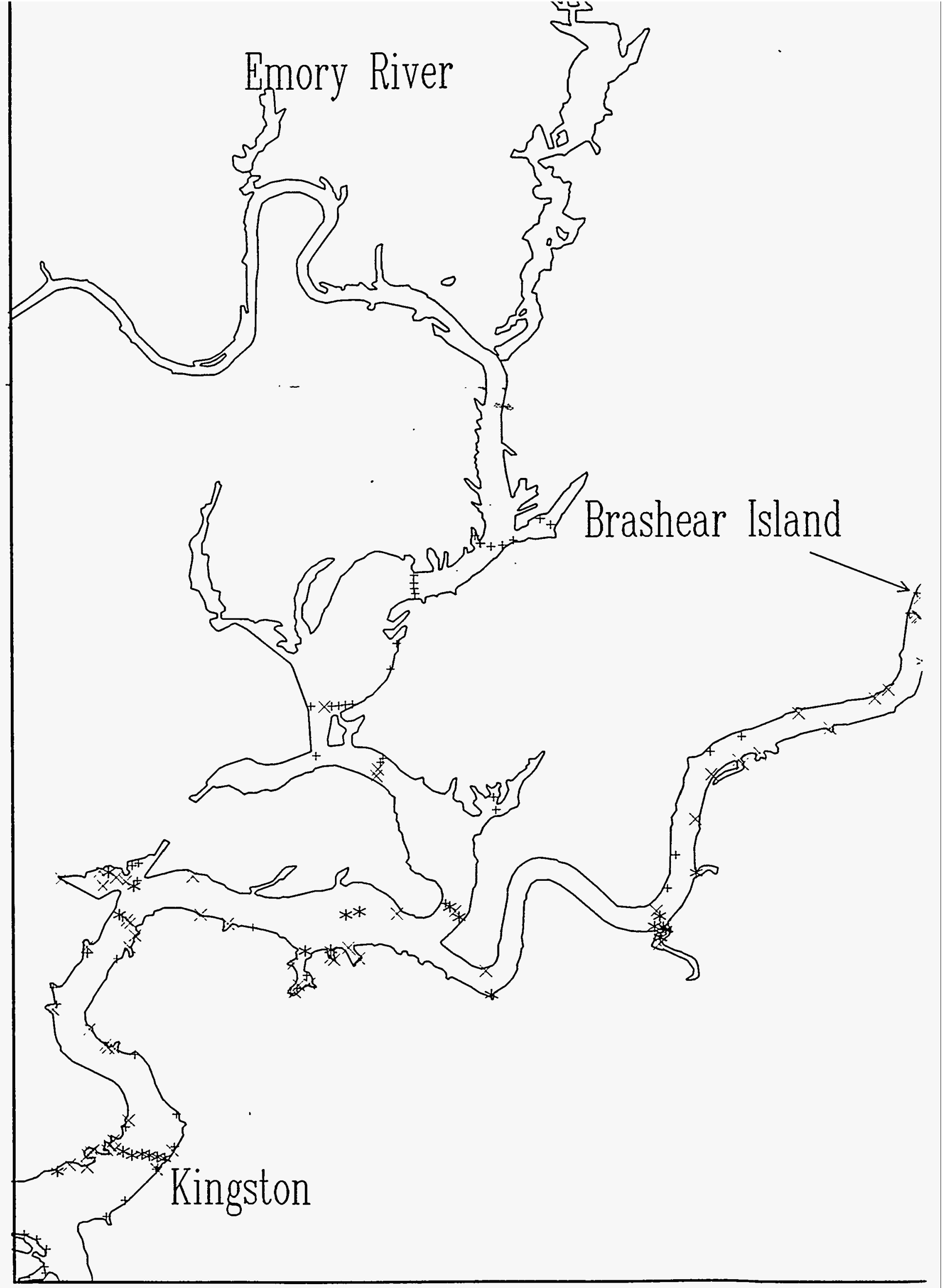





\section{PLATE 1}

Sample locations and Cesium-137 concentrations surface sediments in lower Watts Bar Reservoir 
Summer pool elevation

Winter pool elevation

Original channel

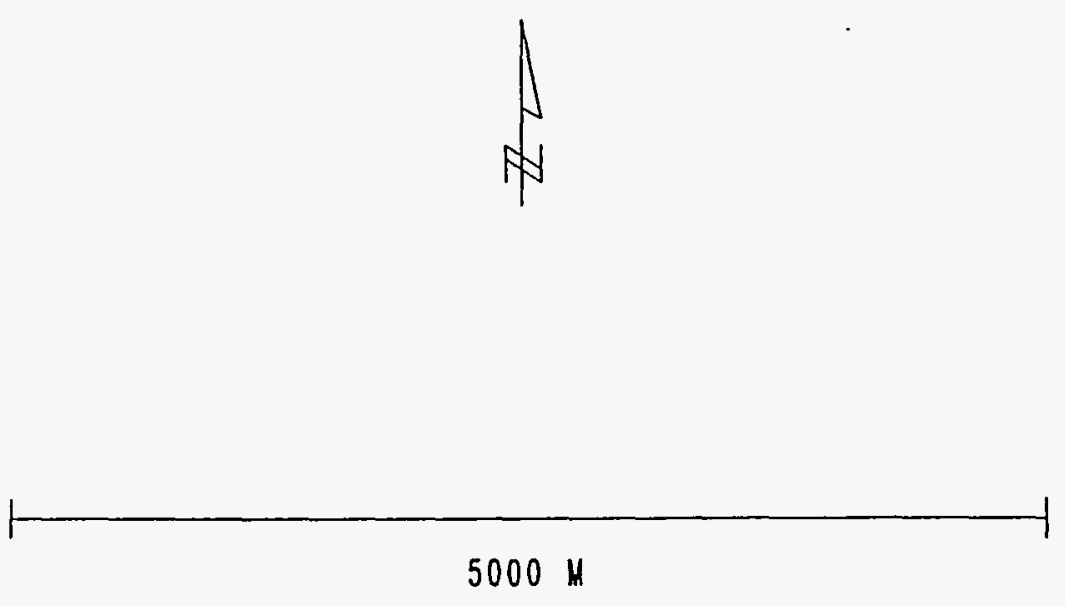

The boundaries of Watts Bar Reservoir for this map are from scanned contour data from 1940 pre-impoundment USGS 7.5 minute quadrangle maps. The outside line defines the summer pool at 741 feet elevation above mean sea level, the dotted line is the original channel, and the light line defines the winter pool of the lake at 735 feet elevation. The scanned data were processed with GRASS software and moved to ARC/INFO for the production of the map. The units are meters. Same map scale as Plate 2. August 1994.

Map produced for ORNL/ER-264. 
Gj

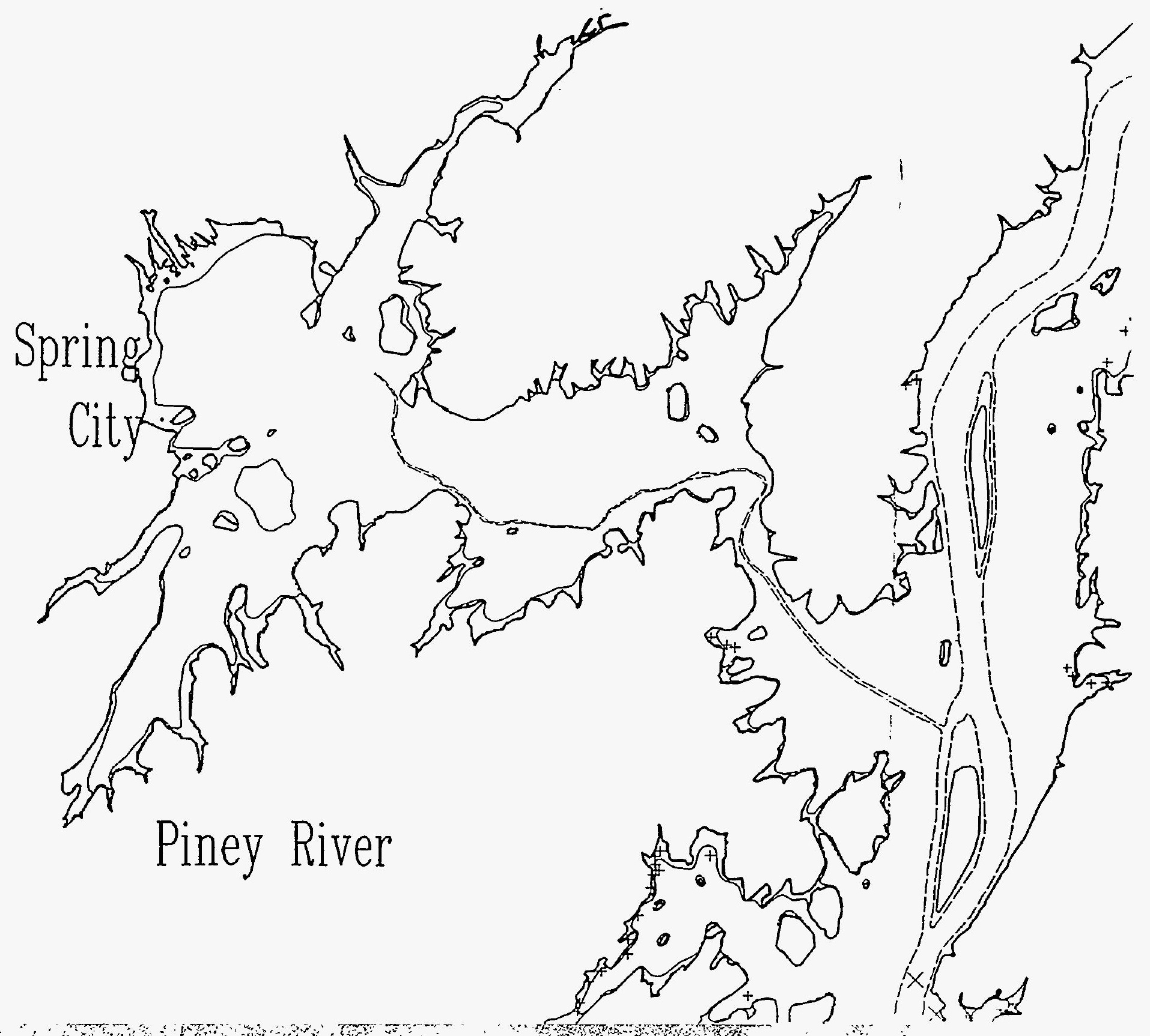

